Overview of Environmental and Hydrogeologic Conditions at Nine Coastal and Island Sites in South-Central and Southeast Alaska

U.S. GEOLOGICAL SURVEY

Open-File Report 95-404

Prepared in cooperation with the FEDERAL AVIATION ADMINISTRATION

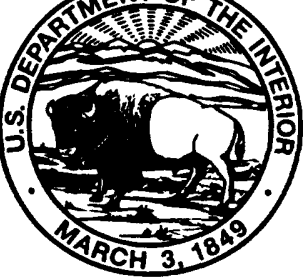




\section{Overview of Environmental and Hydrogeologic \\ Conditions at Nine Coastal and Island Sites in \\ South-Central and Southeast Alaska}

By Eppie V. Hogan

U.S. GEOLOGICAL SURVEY

Open-File Report 95-404

Prepared in cooperation with the

FEDERAL AVIATION ADMINISTRATION 


\section{U.S. DEPARTMENT OF THE INTERIOR \\ BRUCE BABBITT, Secretary}

\section{U.S. GEOLOGICAL SURVEY}

Gordon P. Eaton, Director

For additional information write to:

District Chief

U.S. Geological Survey

4230 University Drive, Suite 201

Anchorage, AK 99508-4664
Copies of this report may be purchased from:

U.S. Geological Survey

Open-File Section

Box 25286, MS 517

Federal Center

Denver, CO 80225-0425 


\section{CONTENTS}

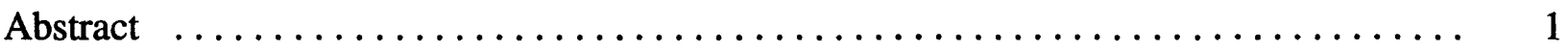

Introduction $\ldots \ldots \ldots \ldots \ldots \ldots \ldots \ldots \ldots \ldots \ldots \ldots \ldots \ldots \ldots \ldots \ldots \ldots$

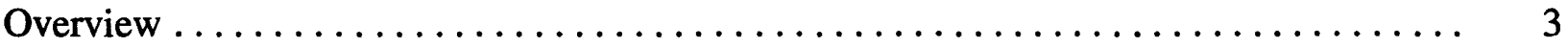

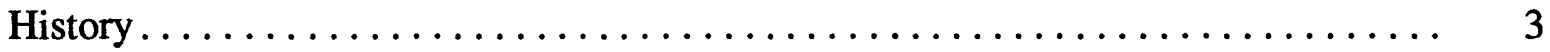

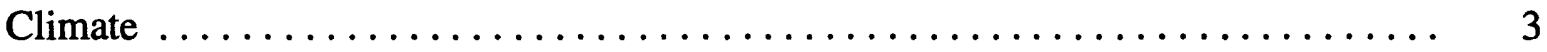

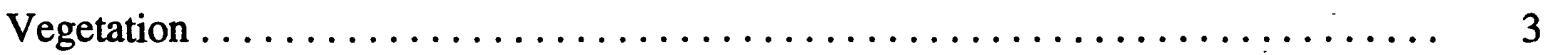

Geology ..................................... 4

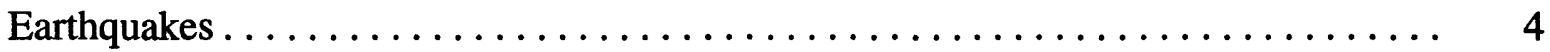

Hydrology ................................... 4

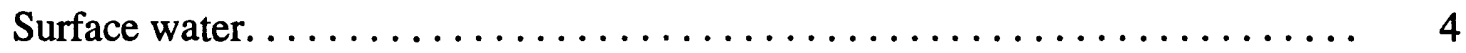

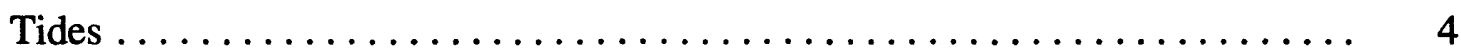

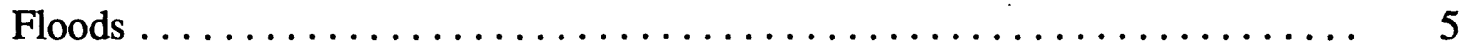

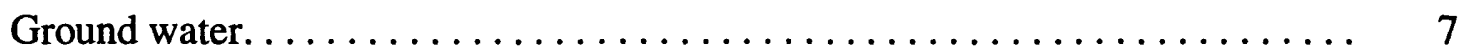

Middleton Island $\ldots \ldots \ldots \ldots \ldots \ldots \ldots \ldots \ldots \ldots \ldots \ldots \ldots \ldots \ldots \ldots \ldots$

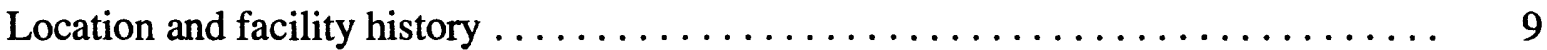

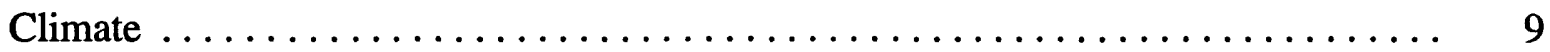

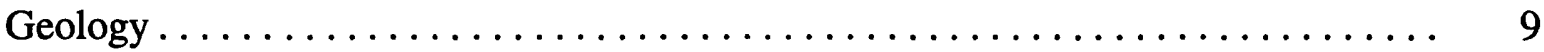

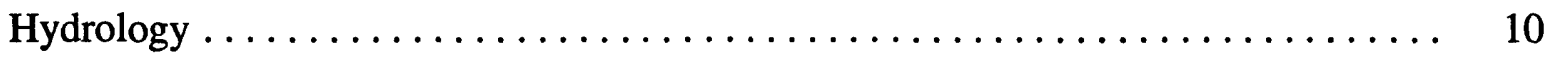

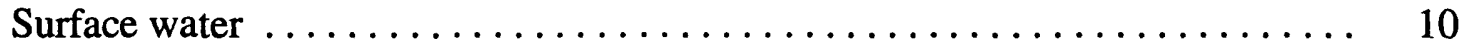

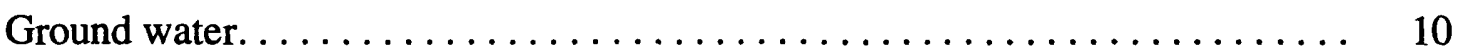

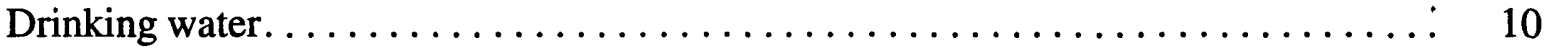

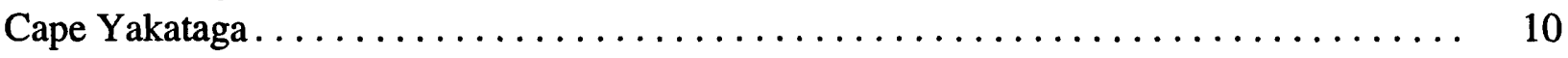

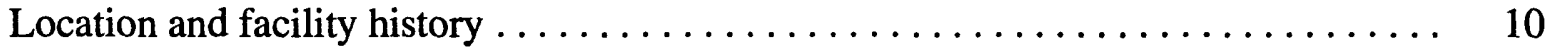

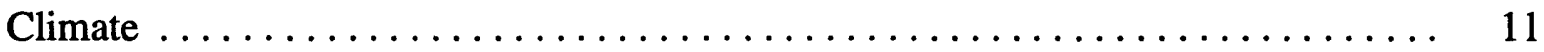

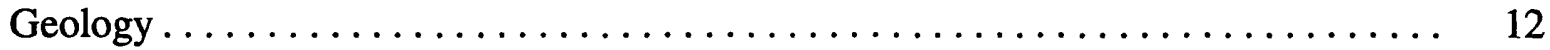

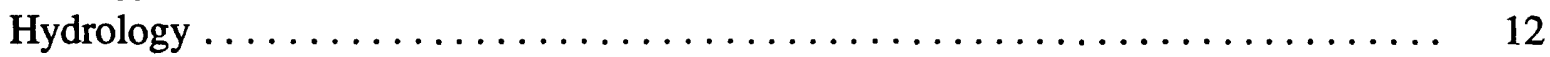

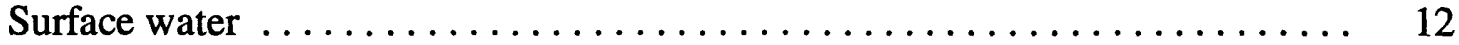

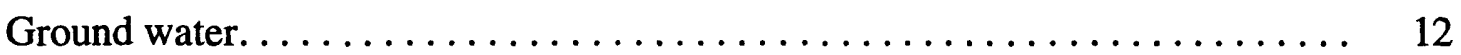

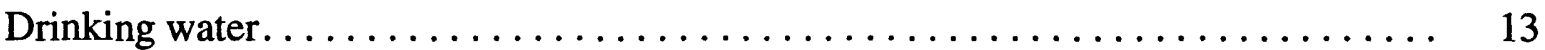

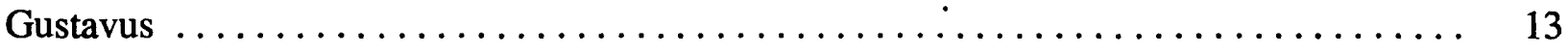

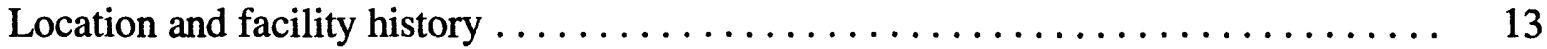

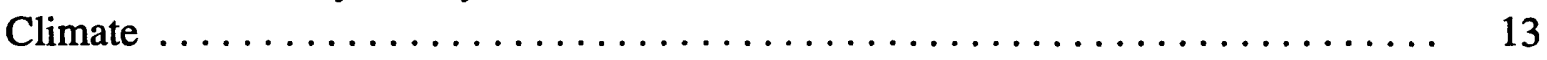

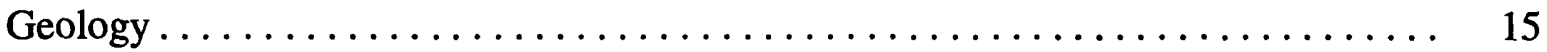

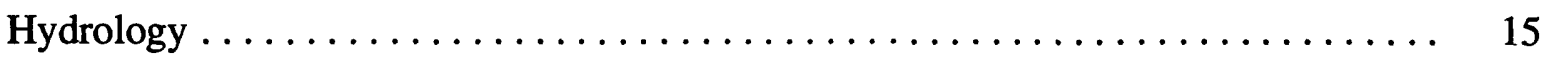

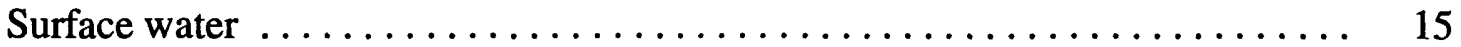

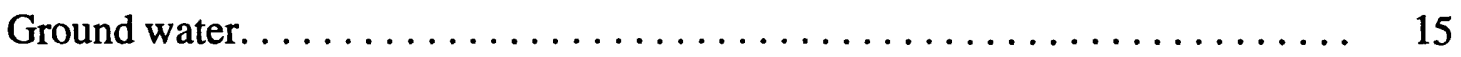

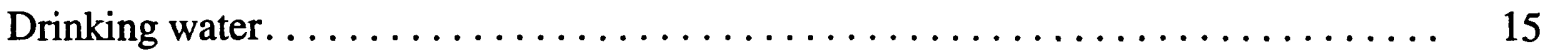

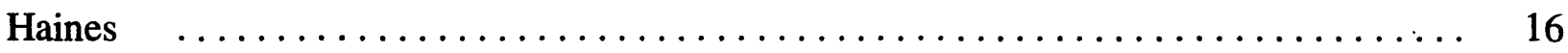

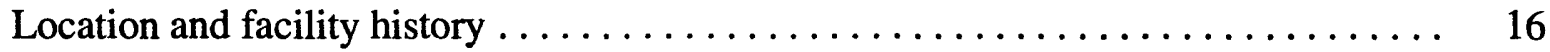

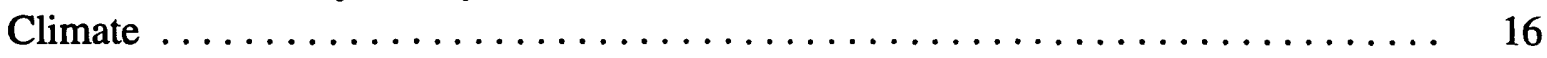

Geology ................................. 18 


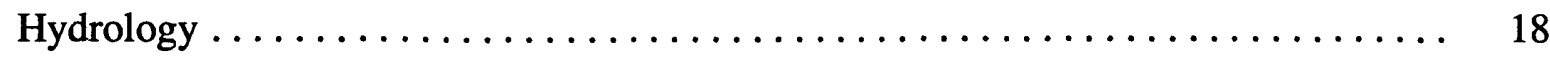

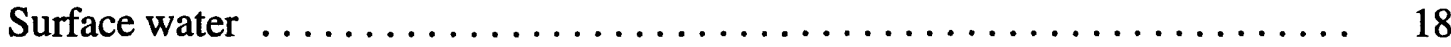

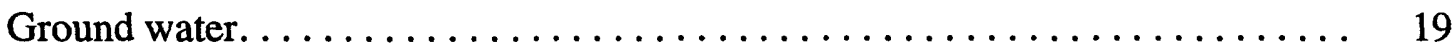

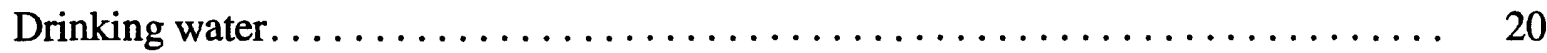

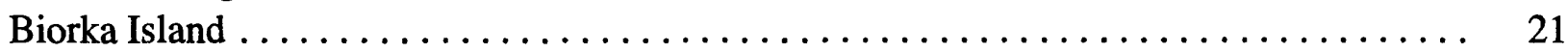

Location and facility history $\ldots \ldots \ldots \ldots \ldots \ldots \ldots \ldots \ldots \ldots \ldots \ldots \ldots \ldots \ldots \ldots \ldots \ldots \ldots, 21$

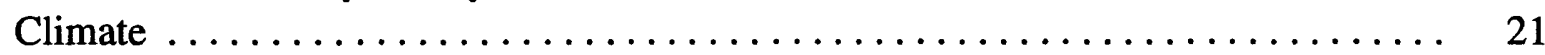

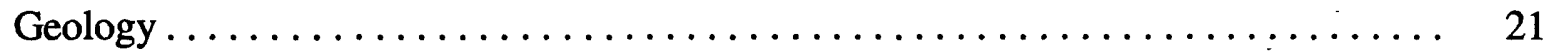

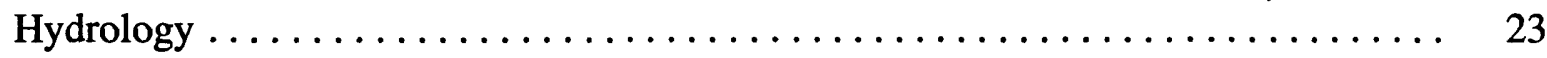

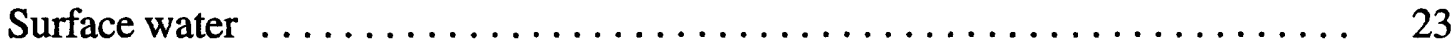

Ground water. . . . . . . . . . . . .

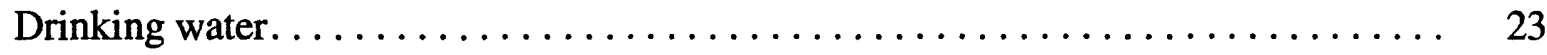

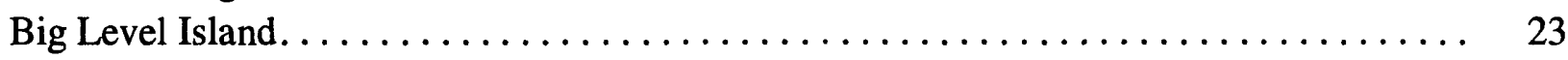

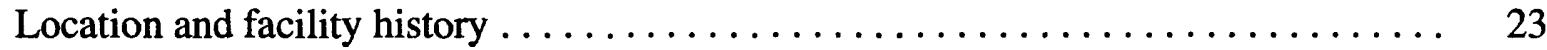

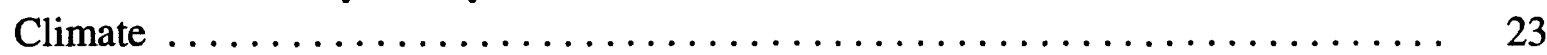

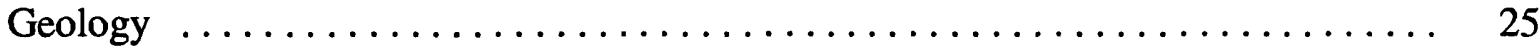

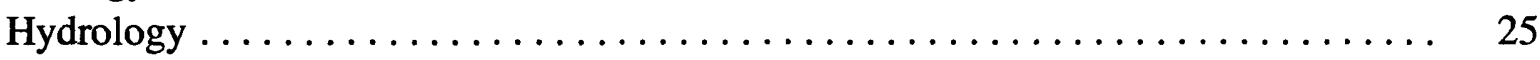

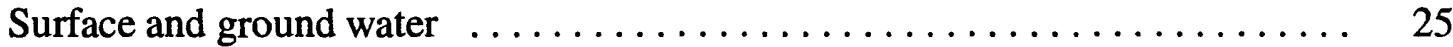

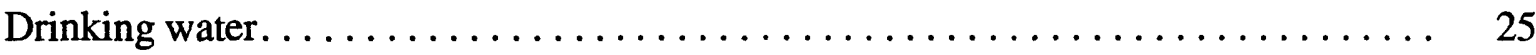

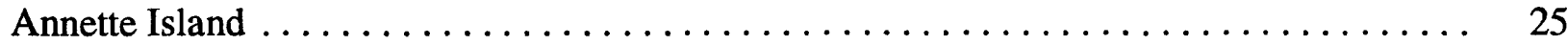

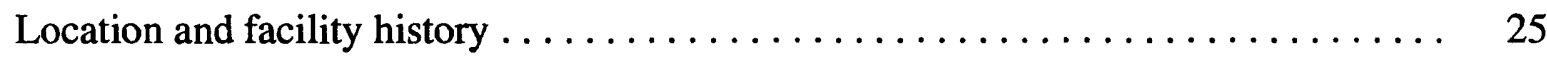

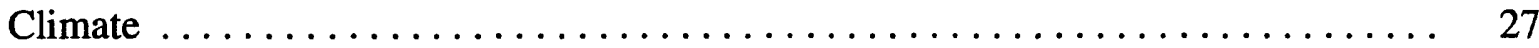

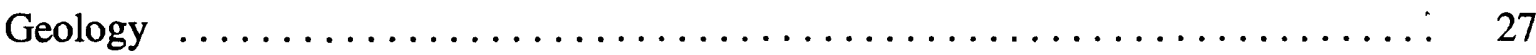

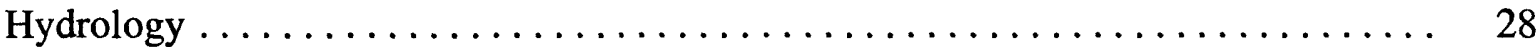

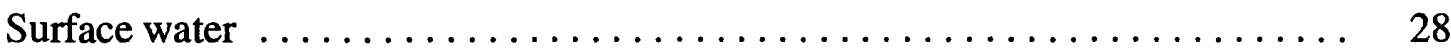

Ground water. . . . . . . . . . . .

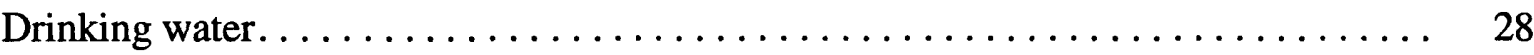

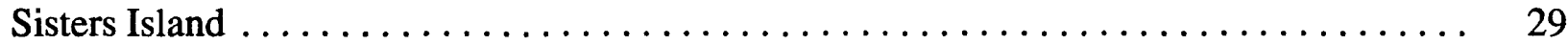

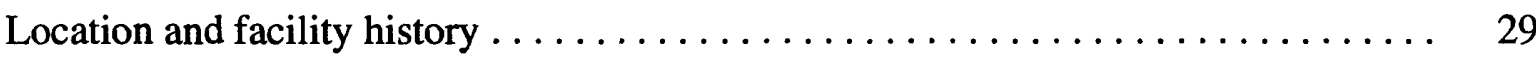

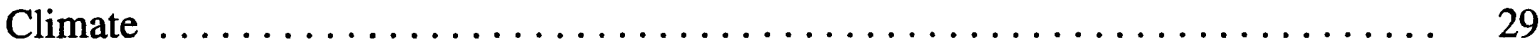

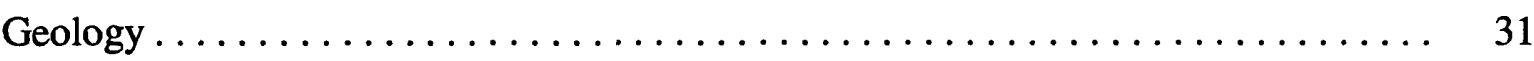

Hydrology $\ldots \ldots \ldots \ldots \ldots \ldots \ldots \ldots \ldots \ldots \ldots \ldots \ldots \ldots \ldots \ldots \ldots \ldots \ldots \ldots, 31$

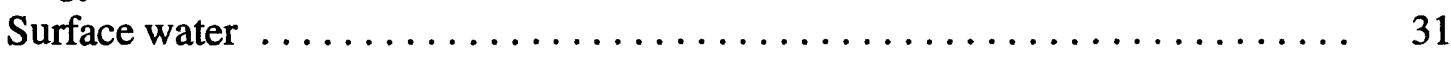

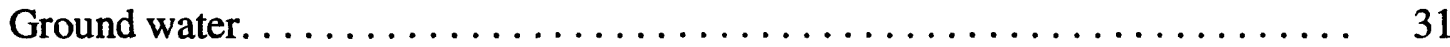

Drinking water. $\ldots \ldots \ldots \ldots \ldots \ldots \ldots \ldots \ldots \ldots \ldots \ldots \ldots \ldots \ldots \ldots \ldots \ldots \ldots, \quad 32$

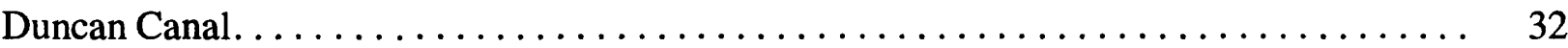

Location and facility history $\ldots \ldots \ldots \ldots \ldots \ldots \ldots \ldots \ldots \ldots \ldots \ldots \ldots, 32$

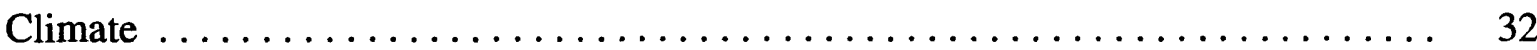

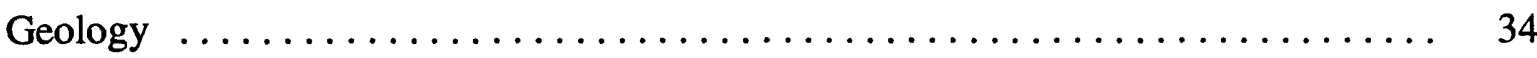

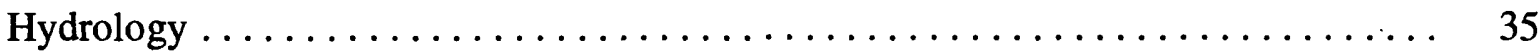

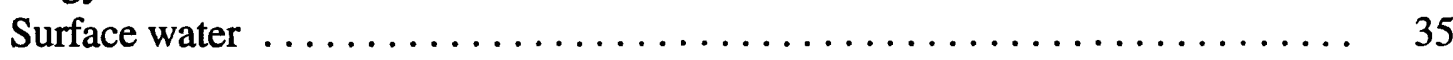

Ground water. . . . . . . . . . . . .

Drinking water. $\ldots \ldots \ldots \ldots \ldots \ldots \ldots \ldots \ldots \ldots \ldots \ldots \ldots \ldots \ldots \ldots \ldots \ldots \ldots \ldots \ldots, \quad 35$ 


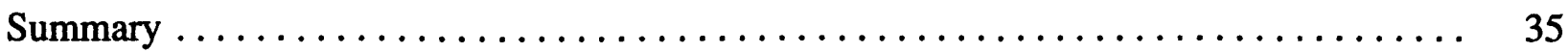

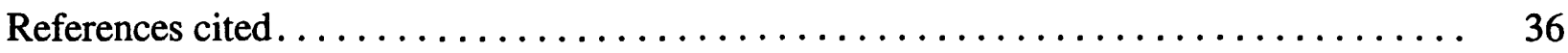

\section{APPENDIXES}

1. Data for Middleton Island, Alaska $\ldots \ldots \ldots \ldots \ldots \ldots \ldots \ldots \ldots \ldots \ldots \ldots \ldots \ldots \ldots \ldots$

2. Data for Cape Yakataga, Alaska, ........................ A-2

3. Data for Gustavus, Alaska $\ldots \ldots \ldots \ldots \ldots \ldots \ldots \ldots \ldots \ldots \ldots \ldots \ldots$ A-3

4. Data for Haines, Alaska. . . . . . . . . . . . . .

5. Data for Biorka Island, Alaska $\ldots \ldots \ldots \ldots \ldots \ldots \ldots \ldots \ldots \ldots \ldots \ldots \ldots \ldots \ldots \ldots$

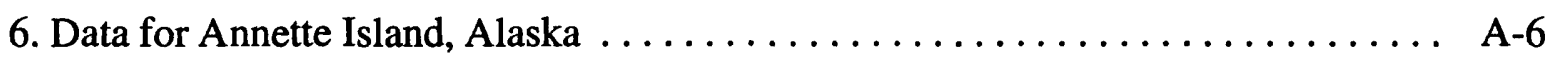

\section{FIGURES}

1. Map showing location of nine coastal and island sites in south-central and southeast Alaska $\ldots \ldots \ldots \ldots \ldots \ldots \ldots \ldots \ldots \ldots$

2. Map showing location of Middleton Island, Alaska, and the Federal Aviation Administration facilities

3. Map showing location of Cape Yakataga, Alaska, and the Federal Aviation Administration facilities

4. Map showing location of Gustavus, Alaska, and the Federal Aviation Administration facility

5. Map showing location of Haines, Alaska, and the Federal Aviation Administration facilities

6. Hydrograph showing daily mean discharge of the Chilkat River near Klukwan, water year $1960 \ldots \ldots \ldots \ldots \ldots \ldots \ldots$

7. Map showing location of Biorka Island, Alaska, and the Federal Aviation Administration facilities

8. Map showing location of Big Level Island, Alaska, and the Federal Aviation Administration facility

9. Map showing location of Annette Island, Alaska, and the Federal Aviation Administration facilities

10. Map showing location of Sisters Island, Alaska, and the Federal Aviation Administration facility

11. Map showing location of Duncan Canal, Alaska, and the Federal Aviation Administration facility 


\section{TABLES}

1. Estimated tide data near FAA facilities . . . . . . . . . . . . . . . . . 5

2. Estimated maximum wave heights for selected return periods ............ 6

3. Flood-hazard ratings for nine coastal and island sites ................ 7

4. Mean monthly and annual temperature, precipitation and snowfall, Middleton

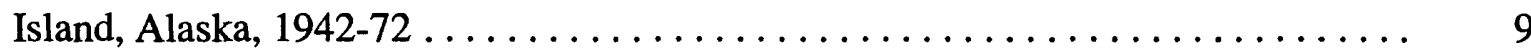

5. Mean monthly and annual temperature, precipitation and snowfall, Yakataga, Alaska, $1943-83$. . . . . . . . . . . . . . . . . . . . . . . 11

6. Mean monthly and annual temperature, precipitation and snowfall,

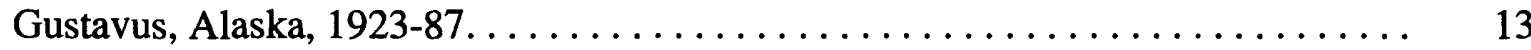

7. Concentrations of selected inorganic constituents in ground water

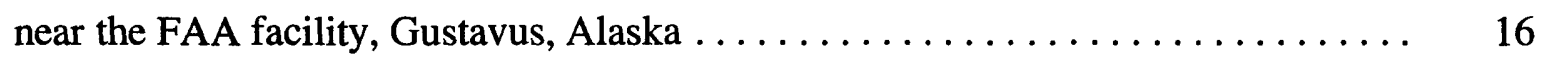

8. Mean monthly and annual temperature, precipitation and snowfall,

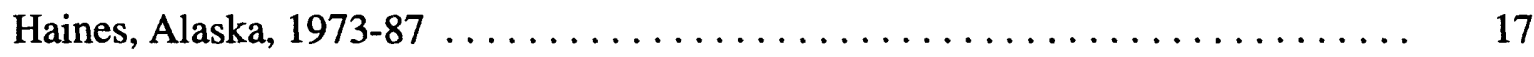

9. Mean monthly and annual flow at gaging-station 15056500 , Chilkat River

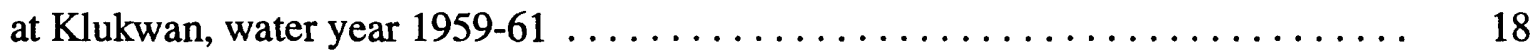

10. Concentrations of selected inorganic constituents in ground water near Haines, Alaska . . . . . . 20

11. Mean monthly and annual temperature, precipitation and snowfall

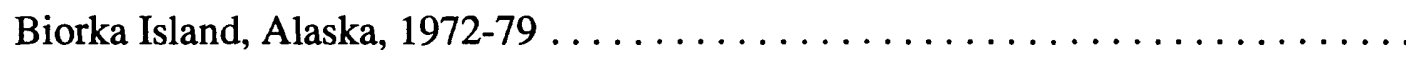

12. Mean monthly and annual temperature, precipitation and snowfall,

Big Level Island, Alaska, $1973-78 \ldots \ldots \ldots \ldots \ldots \ldots \ldots \ldots \ldots \ldots . \ldots \ldots . \ldots \ldots$

13. Mean monthly and annual temperature, precipitation and snowfall,

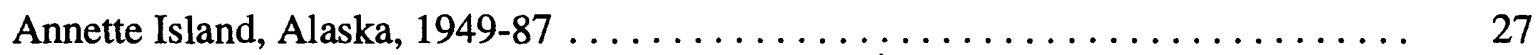

14. Water-quality data for Annette Island, Alaska.................... 29

15. Mean monthly and annual temperature, precipitation, and snowfall,

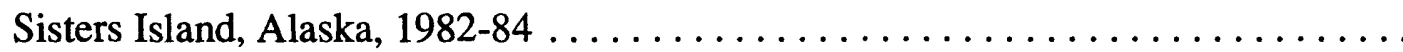

16. Mean monthly and annual temperature, precipitation, and snowfall,

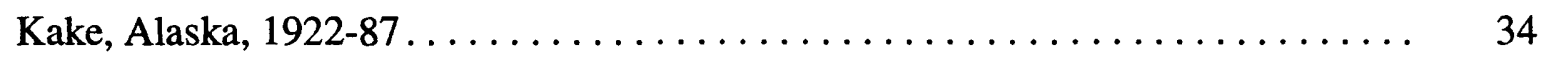

17. Mean monthly and annual temperature, precipitation, and snowfall,

Petersburg, Alaska, $1922-87 \ldots \ldots \ldots \ldots \ldots \ldots \ldots \ldots \ldots \ldots \ldots \ldots \ldots$ 


\section{CONVERSION FACTORS}

\begin{tabular}{lll}
\hline Multiply & By & To obtaln \\
\hline centimeter $(\mathrm{cm})$ & 0.3937 & inch \\
millimeter $(\mathrm{mm})$ & 0.03937 & inch \\
meter $(\mathrm{m})$ & 3.281 & foot \\
meter per kilometer $(\mathrm{m} / \mathrm{km})$ & 5.280 & foot per mile \\
kilometer $(\mathrm{km})$ & 0.6214 & mile \\
square kilometer $\left(\mathrm{km}^{2}\right)$ & 0.3861 & square mile \\
liter $(\mathrm{L})$ & 0.2642 & gallon \\
liter per second $(\mathrm{L} / \mathrm{s})$ & 15.85 & gallon per minute \\
cubic meter per second $\left(\mathrm{m}^{3} / \mathrm{s}\right)$ & 35.31 & cubic foot per second \\
cubic meter per second per square kilometer & 91.4 & cubic foot per second per square \\
$\left.\left(\mathrm{m}^{3} / \mathrm{s}\right) / \mathrm{km}^{2}\right)$ & & mile \\
\hline
\end{tabular}

In this report, temperature is reported in degrees Celsius $\left({ }^{\circ} \mathrm{C}\right)$, which can be converted to degrees Fahrenheit $\left({ }^{\circ} \mathrm{F}\right)$ by the following equation:

$$
{ }^{\circ} \mathrm{F}=1.8\left({ }^{\circ} \mathrm{C}\right)+32
$$

\section{ABBREVIATED WATER-QUALITY UNITS}

Chemical concentration and water temperature are given only in metric units. Chemical concentration in water is given in milligrams per liter $(\mathrm{mg} / \mathrm{L})$ or micrograms per liter $(\mu \mathrm{g} / \mathrm{L})$. Milligrams per liter is a unit expressing the solute mass per unit volume (liter) of water. One thousand micrograms per liter is equivalent to 1 milligram per liter. For concentrations less than 7,000 milligrams per liter, the numerical value is about the same as for concentrations in parts per million.

\section{VERTICAL DATUM}

Sea level: In this report, "sea level" refers to the National Geodetic Vertical Datum of 1929-A geodetic datum derived from a general adjustment of the first-order level nets of the United States and Canada, formerly called Sea Level Datum of 1929. 


\title{
Overview of Environmental and Hydrogeologic Conditions at Nine Coastal and Island Sites in South-Central and Southeast Alaska
}

\author{
By Eppie V. Hogan
}

\section{ABSTRACT}

The Federal Aviation Administration owns or operates airway-support facilities at Middleton Island, Cape Yakataga, Gustavus, Haines, Biorka Island, Big Level Island, Annette Island, Sisters Island, and Duncan Canal. They wish to consider the environmental setting and hydrogeologic conditions when evaluating options for environmental remediation at these facilities. These coastal and island sites in south-central and southeast Alaska have a maritime climate characterized by mild winters and cool summers. Vegetation consists of coastal hemlock-spruce forest. Bedrock consists of sedimentary, volcanic, and metamorphic rocks that are either exposed or very near the land surface throughout the region. Relatively thin surficial deposits cover much of the lowland areas but are minimal or nonexistent in upland areas. Soils are continuous over the land surface except in areas of steep relief or areas covered by ice and snow. Most communities obtain their drinking water from surface-water sources, such as lakes, streams, and rivers. A few communities use water from shallow aquifers. Surface spills and disposal of hazardous materials may affect the quality of drinking water. Alternative drinking-water sources for residents in this area of Alaska include both surface water and ground water. Ground water may be found within fractured bedrock or unconsolidated deposits.

\section{INTRODUCTION}

The Federal Aviation Administration (FAA) owns and (or) operates airway-support and navigational facilities throughout Alaska. Fuels and potentially hazardous materials such as solvents, polychlorinated biphenyls (PCB's), and pesticides may have been used and (or) disposed of at many of these sites. The FAA is conducting comprehensive environmental studies mandated by the Comprehensive Environmental Response, Compensation, and Liability Act (CERCLA) and the Resource Conservation and Recovery Act (RCRA) to determine if environmentally hazardous materials have been spilled or disposed of at these sites. This report is a review and summary of existing hydrologic and geologic data, and other pertinent information for areas surrounding nine sites in coastal and island settings in south-central and southeast Alaska. The report provides information for the FAA facilities and nearby communities at Middleton Island, Cape Yakataga, Gustavus, Haines, Biorka Island, Big Level Island, Annette Island, Sisters Island, and Duncan Canal (fig. 1). 

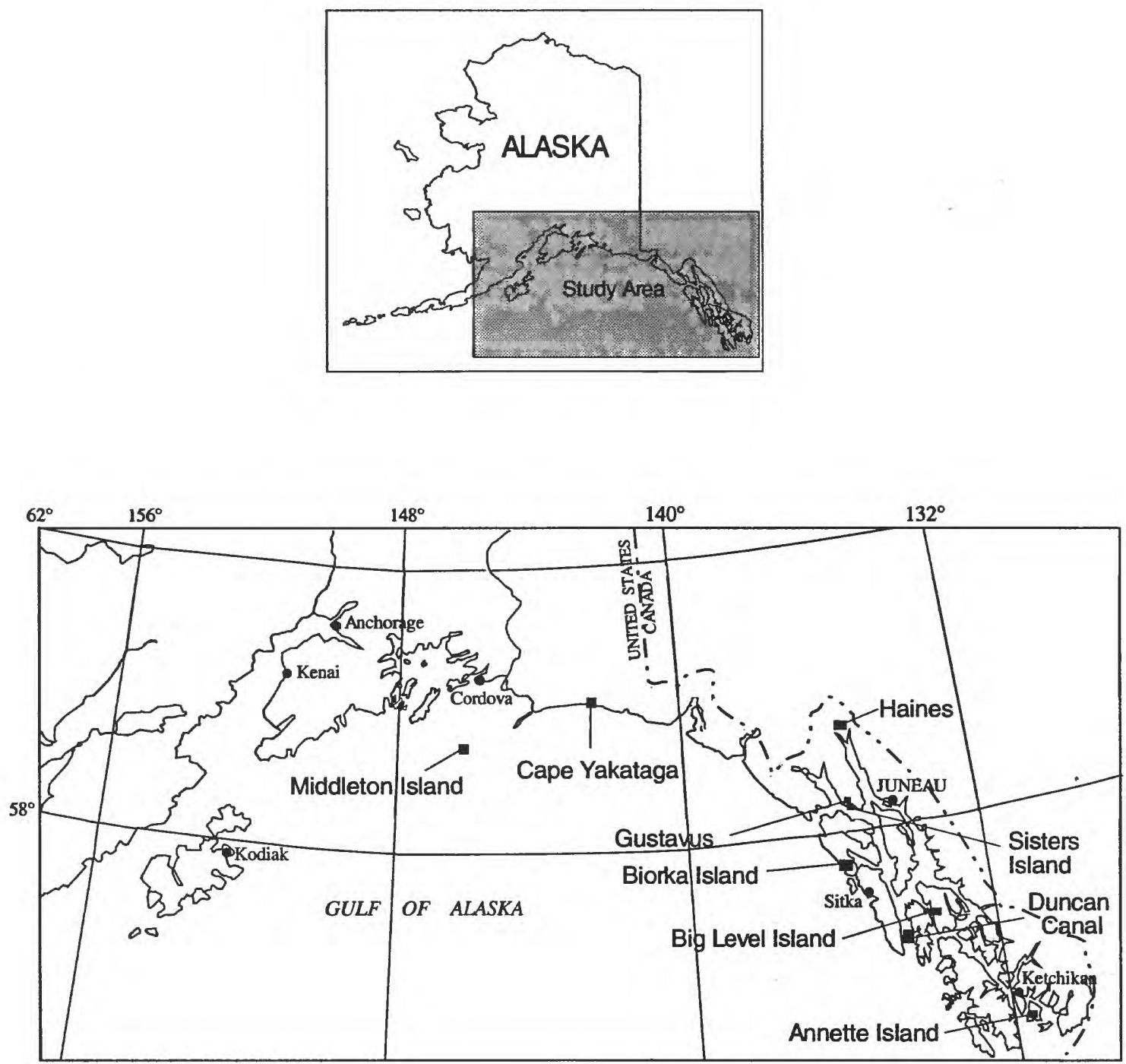

Base adapted from U.S. Geological Survey Map C

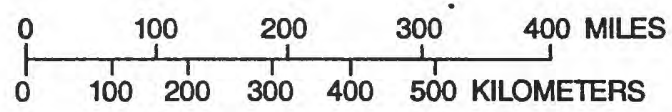

Figure 1. Location of nine coastal and island sites in south-central and southeast Alaska. 


\section{OVERVIEW}

\section{History}

At the time of first western contact, two groups of Indians occupied coastal and island areas in south-central and southeast Alaska, the Tlingit and the Haida. Their settlement patterns were dictated by the variety and abundance of natural resources. Trade also was an integral part of their economic and social life (Selkregg, 1976).

In the early 18th century, a series of Russian voyages were made in an effort to locate the western opening of the Northwest Passage. Explorers landed at Cape St. Elias on July 17, 1741, marking the first European landfall on the coast of southeastern Alaska. Over the next several years, the Russians continued to move east in search of new sea otter hunting grounds. In 1804, the Russians established a capital at Sitka. The Russian hold on southeastern Alaska was tenuous and was challenged in the early 1820's by England and America (Selkregg, 1976).

In 1867, the United States purchased Alaska from Russia. After the discovery of gold in the late 1800's, southeastern Alaska's population boomed. Wrangell, Petersburg, Ketchikan, Craig, and other small towns were established, and in 1900, Juneau became the capital of the new territory (Selkregg, 1976).

The economy of this area of Alaska is dependent on natural resources, particularly marine resources, minerals, and forest products. Growth in State and local governments has provided employment opportunities and has stimulated development in other economic areas including tourism, retail trade, construction, and transportation services (Selkregg, 1976).

\section{Climate}

Climate in coastal areas of south-central and southeast Alaska is dominated by maritime influences (Hartman and Johnson, 1984). Climatic conditions are characterized by small temperature variations, high humidity, heavy precipitation, and frequent cloudy and foggy periods. Summers are cool and winters are mild. Surface winds generally are strong and persistent (Hartman and Johnson, 1984). Data on the local climate conditions are presented on a site-by-site basis later in this report.

\section{Vegetation}

Vegetation in coastal areas of south-central and southeast Alaska consists principally of coastal western hemlock and Sitka spruce forest. The vegetation is characterized by an overstory of Sitka spruce, western hemlock, Alaska cedar, and black cottonwood and an understory of blueberry, five-leaf bramble, gold thread, and several types of ferns, lichens, and mosses (Viereck and Little, 1972). Muskeg vegetation exists in many places on local islands and includes sphagnum moss, Labrador tea, and bog rosemary. Shoreline vegetation, common along coastal areas, includes silverweed, hair grass, yarrow, buttercup, and a variety of sedges. Alpine vegetation, starting at about $600 \mathrm{~m}$ above mean sea level includes mountain hemlock, low mat-forming shrubs, deer cabbage, heather, lichen, berries, and willow (Environmental Services Ltd., 1979). 


\section{Geology}

In general, bedrock is either exposed or very near the land surface throughout the coastal and island areas of south-central and southeast Alaska. Bedrock consists of sedimentary, volcanic, and metamorphic rocks (Berg and Gehrels, 1992). The predominant northwest-trending bedrock pattern contains many folds and faults (Selkregg, 1976). Most of the bedrock in these areas of Alaska is overlain by unconsolidated deposits of Quaternary age (Berg and Gehrels, 1992). Surficial materials cover much of the lowland areas but are minimal or nonexistent in upland areas (Berg and Gehrels, 1992). Soils are continuous over the land surface except in areas of steep relief or areas covered by ice and snow.

\section{Earthquakes}

The nine FAA facilities described in this report lie within the active circum-Pacific seismic belt. Middleton Island and Cape Yakataga are near the Aleutian Trench, the Yakataga Seismic Gap, and the St. Elias fault. The rest of the facilities are in an area traversed by the Chatham Strait fault, the Fairweather fault, and numerous smaller faults (Brower and others, 1977; Stephens and others, 1986). In recent years, several earthquakes with Richter scale magnitudes greater than 7 have been recorded (Brower and others, 1977). The Yakataga Seismic Gap is considered to be a likely site for a 7.8 or larger earthquake within the next decade (Stephens and others, 1986). Much of the land in south-central and southeast Alaska has been uplifted since the last glaciation as shown by the widespread presence of emergent marine deposits (Selkregg, 1976). Studies on Middleton Island indicate a significant amount of vertical displacement as a result of past seismic activity (Prescott and Lisowski, 1977). Large, fast-moving sea waves (tsunamis) generated by earthquakes are a potential hazard for most coastal and island communities (U.S. Army Corps of Engineers, 1993; Brower and others, 1977).

\section{Hydrology}

\section{Surface Water}

Parts of Alaska's Pacific coast receive more than $2,500 \mathrm{~mm} / \mathrm{yr}$ of precipitation (Hartman and Johnson, 1984). Because of steep topographic gradients, most of this precipitation runs off rapidly into lakes and streams as surface water, and only a minor amount infiltrates to the ground-water system (Selkregg, 1976). Most of the small lakes, rivers, and creeks in southeast Alaska drain from the west side of the Coast Mountains and St. Elias Mountains, and from the islands of the Archipelago directly into the sea. South-central and southeast Alaska are free of permafrost (Ferrians, 1980). Mean annual runoff rates range from about 0.02 to more than $0.14\left(\mathrm{~m}^{3} / \mathrm{s}\right) / \mathrm{km}^{2}$ (B.B. Bigelow, U.S. Geological Survey, written commun., 1995).

Tides

A two-layered estuarine circulation system is a common phenomenon in coastal areas of Alaska and is most likely to occur in protected bays and along passages near the outer coast. In this system, fresh water flows seaward along the surface and is replaced by sea water flowing toward the coast at greater depths. Fall storms, reduced runoff during the winter, and tidal variations combine to mix the layers and destroy the system (U.S. Army Corps of Engineers, 1989). Brower 
and others (1977) discuss diurnal tidal ranges, as well as the maximum and minimum tides predicted to occur at several coastal and island sites in Alaska. Estimated data for sites near FAA facilities are given in table 1.

Table 1. Estimated tide data near FAA facilities

[Diurnal range is the average difference in height between mean higher high water and mean lower low water in meters on a single day; maximum and minimum tide are the highest and lowest tide predicted to occur at the location in meters above mean sea level, a negative number indicates a level below mean sea level. $\mathrm{m}$, meters]

\begin{tabular}{lccc}
\hline Location & $\begin{array}{c}\text { Diurnal range } \\
(\mathrm{m})\end{array}$ & $\begin{array}{c}\text { Maximum tide } \\
(\mathrm{m})\end{array}$ & $\begin{array}{c}\text { Minimum tide } \\
(\mathrm{m})\end{array}$ \\
\hline Middleton Island & 3.6 & 4.5 & -1.0 \\
Cape Yakataga & 3.0 & 3.8 & -0.8 \\
Gustavus & 4.5 & 5.7 & -1.4 \\
Haines & 5.1 & 6.3 & -1.4 \\
Biorka Island & 3.0 & 3.8 & -0.8 \\
Big Level Island & 4.8 & 5.9 & -1.2 \\
Annette Island & 4.6 & 5.8 & -1.3 \\
Sisters Island & 4.5 & 5.7 & -1.4 \\
Duncan Canal & 4.6 & 5.8 & -1.3 \\
\hline
\end{tabular}

Floods

Although most of the island and coastal communities in south-central and southeast Alaska have low flood-hazard ratings, they are vulnerable to some degree of flooding by storm-driven or tsunami waves (U.S. Army Corps of Engineers, 1993). Tsunami waves are generated by seismic activity and are capable of traveling great distances across water striking shore areas with potentially destructive effects. Storm-driven waves also can affect low-lying coastal communities but have less potential to travel inland because of reduced wave velocity. Brower and others (1977) describe return periods for maximum wave heights for selected marine areas in Alaska (table 2). A 100-year storm wave that is more than $20 \mathrm{~m}$ in height is estimated for coastal areas in southcentral and southeast Alaska. 
Table 2. Estimated maximum wave heights for selected return periods

\begin{tabular}{lcc}
\hline Location & Return period (years) & $\begin{array}{c}\text { Maximum significant wave } \\
\text { (meters) }\end{array}$ \\
\hline Middleton Island & 5 & 13.0 \\
& 10 & 14.5 \\
& 25 & 17.0 \\
Cape Yakataga & 50 & 19.0 \\
& 100 & 21.5 \\
& 5 & 12.5 \\
& 10 & 14.0 \\
& 25 & 17.0 \\
& 50 & 19.0 \\
Annette Island, Big Level & 100 & 21.5 \\
Island, Biorka Island, & 100 & \\
Gustavus, Haines, Sisters & 50 & 12.0 \\
Island, and Duncan Canal & 5 & 14.0 \\
& & 16.0 \\
& & 18.5 \\
& 50.5 & \\
\hline
\end{tabular}

Overbank flooding of stream channels in south-central and southeast Alaska may occur as the result of intense rainfall augmented by snow and glacier melting (Selkregg, 1976; Jones and Fahl, 1994). Flood crests in southeastern Alaska are typically short in duration and are characterized by a very sharp increase and decrease of flow. Available flood data for Alaskan communities in this report along with the flood-hazard rating are given in table 3. 
Table 3. Flood-hazard ratings for nine coastal and island sites [U.S. Army Corps of Engineers, 1993, unless otherwise noted]

\begin{tabular}{ll}
\hline \multicolumn{1}{c}{ Community } & \multicolumn{1}{c}{ Flood-hazard rating } \\
\hline Middleton Island & $\begin{array}{l}\text { Not available, but assumed low; probably subject to } \\
\text { local drainage problems and (or) tsunamis } \\
\text { Low; glacial outburst flooding has occurred in the past } \\
\text { (Selkregg, 1976) }\end{array}$ \\
Gustavus & $\begin{array}{l}\text { Low; last flood in 1976 due to heavy rains } \\
\text { Low; some flooding in 1988 due to rain on frozen } \\
\text { ground }\end{array}$ \\
Haines & $\begin{array}{l}\text { Low; local tsunami possible } \\
\text { Biorka Island }\end{array}$ \\
Big Level Island & $\begin{array}{l}\text { Not available, but assumed low; probably subject to } \\
\text { local drainage problems and (or) tsunamis }\end{array}$ \\
Annette Island & Low; tsunamis and local drainage may be problems \\
Sisters Island & $\begin{array}{l}\text { Not available, but assumed low; probably subject to } \\
\text { local drainage problems and (or) tsunamis }\end{array}$ \\
Duncan Canal & $\begin{array}{l}\text { Not available, but assumed low; probably subject to } \\
\text { local drainage problems and (or) tsunamis }\end{array}$ \\
\hline
\end{tabular}

\section{Ground Water}

Ground-water data for the FAA facilities in south-central and southeast Alaska are sparse. Water-bearing surficial materials include alluvial and glacial deposits that are found at depths typically ranging from 3 to $30 \mathrm{~m}$ below land surface (Selkregg, 1976). Ground water may also occur in fractured bedrock. Freshwater occurs beneath islands and coastal areas as a "freshwater lens" that floats on saltwater (Hunt and others, 1988). This is sometimes referred to as basal water and it can occur under confined or unconfined conditions (Hunt and others, 1988). Basal water often extends to depths below sea level of about 40 times the water-table elevation or potentiometric surface. Near the base of the lens, freshwater grades into saltwater in a transition zone that may range from a few meters to a few hundred meters (Hunt and others, 1988). The possibility of saltwater intrusion into coastal and island aquifers increases with depth and pumping rate. 


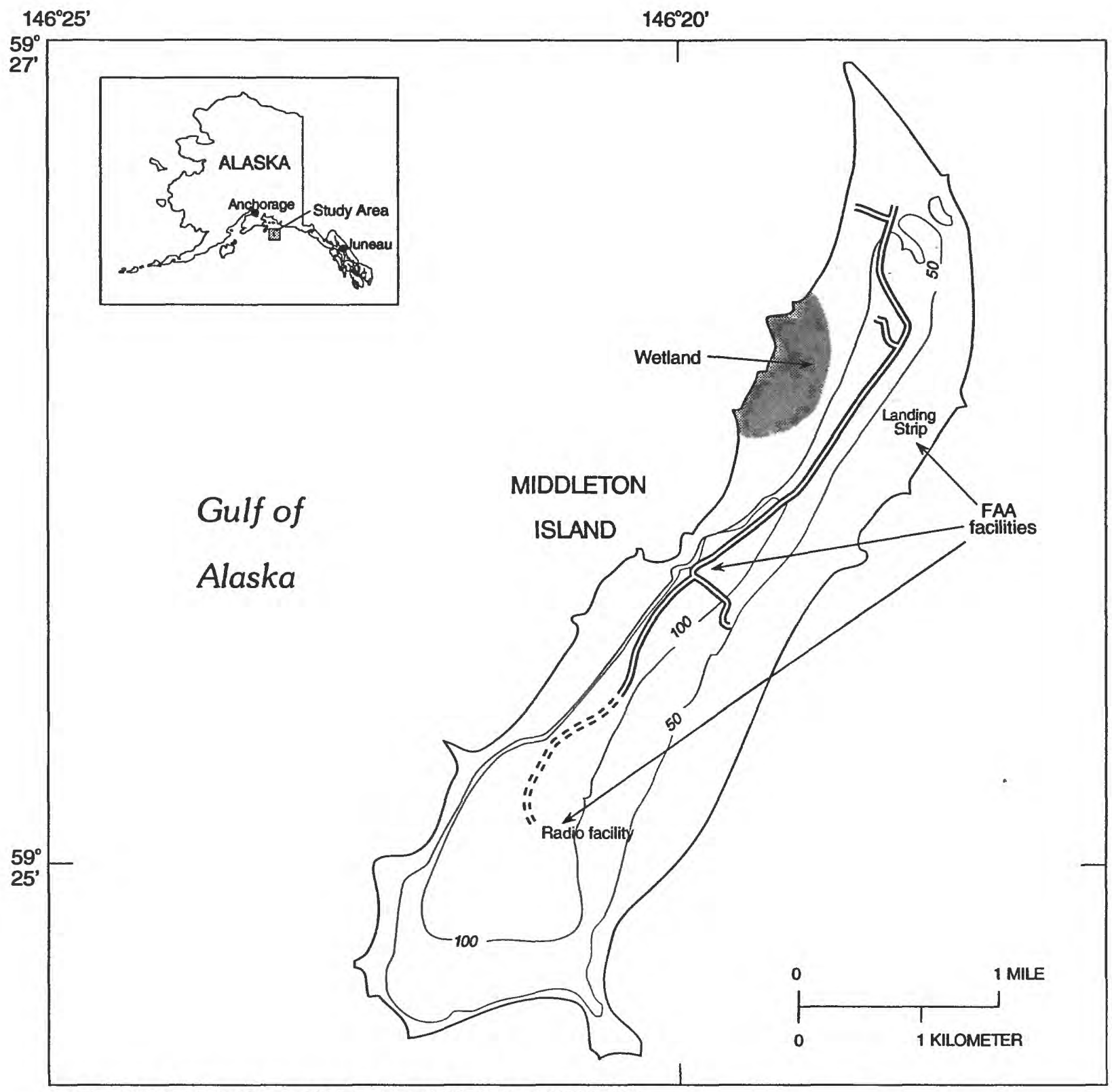

Base from U.S. Geological Survey, Middleton Island (B-7), Alaska, 1:63,360, 1955•

Figure 2. Location of Middleton Island, Alaska and the Federal Aviation Administration facilities. 


\section{MIDDLETON ISLAND}

\section{Location and Facility History}

Middleton Island is a small uninhabited island about $6.5 \mathrm{~km}$ long and about $1.5 \mathrm{~km}$ wide. It is about $200 \mathrm{~km}$ south of Valdez in the Gulf of Alaska at lat $59^{\circ} 27^{\prime} \mathrm{N}$., long $146^{\circ} 18^{\prime} \mathrm{W}$., (figs. 1 and 2). The first FAA navigational aids on Middleton Island were constructed in 1942. The FAA facilities currently include storage buildings, a gravel airstrip, and radio towers. FAA personnel stationed in Kenai carry out facility maintenance. Occupation of FAA buildings occasionally occurs during visits by other Federal agencies conducting seasonal research on Middleton Island. A detailed list of FAA-owned and operated facilities on Middleton Island, and a list of potential sources of contamination can be found in an environmental compliance investigation report by Ecology and Environment, Inc. (1992a).

\section{Climate}

Middleton Island has a mean annual temperature of $5.7^{\circ} \mathrm{C}$. Temperatures range from an August mean maximum of $14.4^{\circ} \mathrm{C}$ to a February mean minimum of $-0.8^{\circ} \mathrm{C}$ (Leslie, 1989). Mean annual precipitation is about $1,460 \mathrm{~mm}$ and mean annual snowfall is about $860 \mathrm{~mm}$. Mean monthly and annual temperature, precipitation, and snowfall are summarized in table 4 (Leslie, 1989).

Table 4. Mean monthly and annual temperature, precipitation, and snowfall, Middleton Island, Alaska, 1942-72

[Modified from Leslie (1989); ${ }^{\circ} \mathrm{C}$, degree Celsius]

\begin{tabular}{|c|c|c|c|c|c|c|c|c|c|c|c|c|c|}
\hline & Jan. & Feb. & Mar. & Apr. & May & June & July & Aug. & Sept. & Oct. & Nov. & Dec. & Annual \\
\hline \multicolumn{14}{|c|}{ Temperature $\left({ }^{\circ} \mathrm{C}\right)$} \\
\hline \multirow[t]{2}{*}{ Mean maximum } & 2.5 & 2.6 & 3.4 & 5.6 & 8.1 & 11.1 & 13.6 & 14.4 & 12.4 & 8.6 & 5.6 & 2.9 & 7.6 \\
\hline & $(\operatorname{Rec}$ & $\mathrm{d}$ maxin & $\mathrm{m} 22.2$ & C, Augu & 1957) & & & & & & & & \\
\hline \multirow[t]{2}{*}{ Mean minimum } & -0.7 & -0.8 & -0.3 & 1.3 & 3.9 & 6.8 & 9.3 & 10.2 & 8.4 & 4.9 & 2.2 & -0.4 & 3.7 \\
\hline & (Rec & $\mathrm{d}$ minim & $m-14.4$ & C, Febr & ary 1947 & & & & & & & & \\
\hline \multirow[t]{5}{*}{ Mean } & 0.9 & 0.9 & 1.6 & 3.4 & 6.0 & 8.9 & 11.4 & 12.3 & 10.4 & 6.8 & 3.9 & 1.3 & 5.7 \\
\hline & & & & Pre & ipitatio & in mill & eters & & & & & & Total \\
\hline & 135 & 100 & 85 & 83 & 92 & 57 & 88 & 122 & 181 & 200 & 176 & 143 & 1,462 \\
\hline & 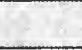 & . & & & lowfall, & millim & ers & : & & & & & Total \\
\hline & 193 & 158 & 178 & 48 & 10 & 0.0 & 0.0 & 0.0 & 0.0 & 15 & 53 & 203 & 858 \\
\hline
\end{tabular}

\section{Geology}

Bedrock on Middleton Island is composed of sedimentary rocks (Winkler and Plafker, 1993). Depth to bedrock typically is less than $10 \mathrm{~m}$ below land surface (Winkler and Plafker, 1993). Middleton Island lies within a major fault system and the geologic record illustrates significant tectonic uplift (Hudson and others, 1976; Prescott and Lisowski, 1977; Winkler and Plafker, 1993). The average uplift rate during the past 4,500 years is about $1 \mathrm{~cm} / \mathrm{yr}$. Unconsolidated deposits on Middleton Island are beach sand and till. The deposits are arranged in a unique series of step-like terraces ranging in height from 3 to $30 \mathrm{~m}$ above mean sea level (Hudson and others, 1976). Beach 
deposits consist of sand, minor amounts of gravel, and silt; till consists of unconsolidated silt, sand, gravel, and boulders.

\section{Hydrology}

\section{Surface Water}

Wetland areas and small ponds compose Middleton Island's surface-water system. Wetland areas extend along $1.5 \mathrm{~km}$ of the northwest coastline (fig. 2). Ponds on the island are shallow and are typically less than $0.02 \mathrm{~km}^{2}$ in area. A topographic gradient of about $60 \mathrm{~m} / \mathrm{km}$ directs water from the center of the island to the coast. Mean annual runoff on the island is estimated to be between 0.1 and $0.2\left(\mathrm{~m}^{3} / \mathrm{s}\right) / \mathrm{km}^{2}$ (B.B. Bigelow, U.S. Geological Survey, written commun., 1995).

\section{Ground Water}

Ground water on Middleton Island is present at depths between 1 and $3 \mathrm{~m}$ below land surface (Winkler and Plafker, 1993). A 3-meter-deep well at the Middleton Island FAA facility reached the aquifer about $1 \mathrm{~m}$ below the land surface (Appendix 1; Ecology and Environment, Inc., 1992a). In general, flow of ground water is likely to follow surface topography toward the coast. The availability of ground water from bedrock is unknown. Ground water is recharged by infiltration of precipitation.

\section{Drinking Water}

Selkregg (1976) reports the use of both ground-water and surface-water sources for drinking water on Middleton Island; however, the FAA facility uses only ground water for drinking-water supplies (Ecology and Environment Inc., 1992a). The drinking-water system, constructed in 1980, is an infiltration gallery with a capacity of about $0.3 \mathrm{~L} / \mathrm{s}$. Before settling and filtration, the water is chemically treated with potassium permanganate, ammonium sulfate, and soda ash (Ecology and Environment Inc., 1992a). Small unnamed ponds represent drinking-water alternatives for Middleton Island. However, the quality and quantity of these water resources is undocumented.

\section{CAPE YAKATAGA}

\section{Location and Facility History}

Cape Yakataga is in the Yakataga Glacial Valley along the Gulf of Alaska. It is about $450 \mathrm{~km}$ southeast of Anchorage near lat $60^{\circ} 03^{\prime}$ N., long $142^{\circ} 25^{\prime}$ W. (figs. 1 and 3). The FAA facilities at Cape Yakataga consist of air-navigation and support equipment that has been operating since May 1942. Facilities include a nondirectional beacon, a powerhouse and shop, employee living quarters, and a beacon tower that are maintained by FAA personnel stationed in Cordova. A detailed list of FAA facilities at Cape Yakataga and potential sources of contamination can be found in an environmental compliance investigation report by Ecology and Environment Inc. (1992b). 


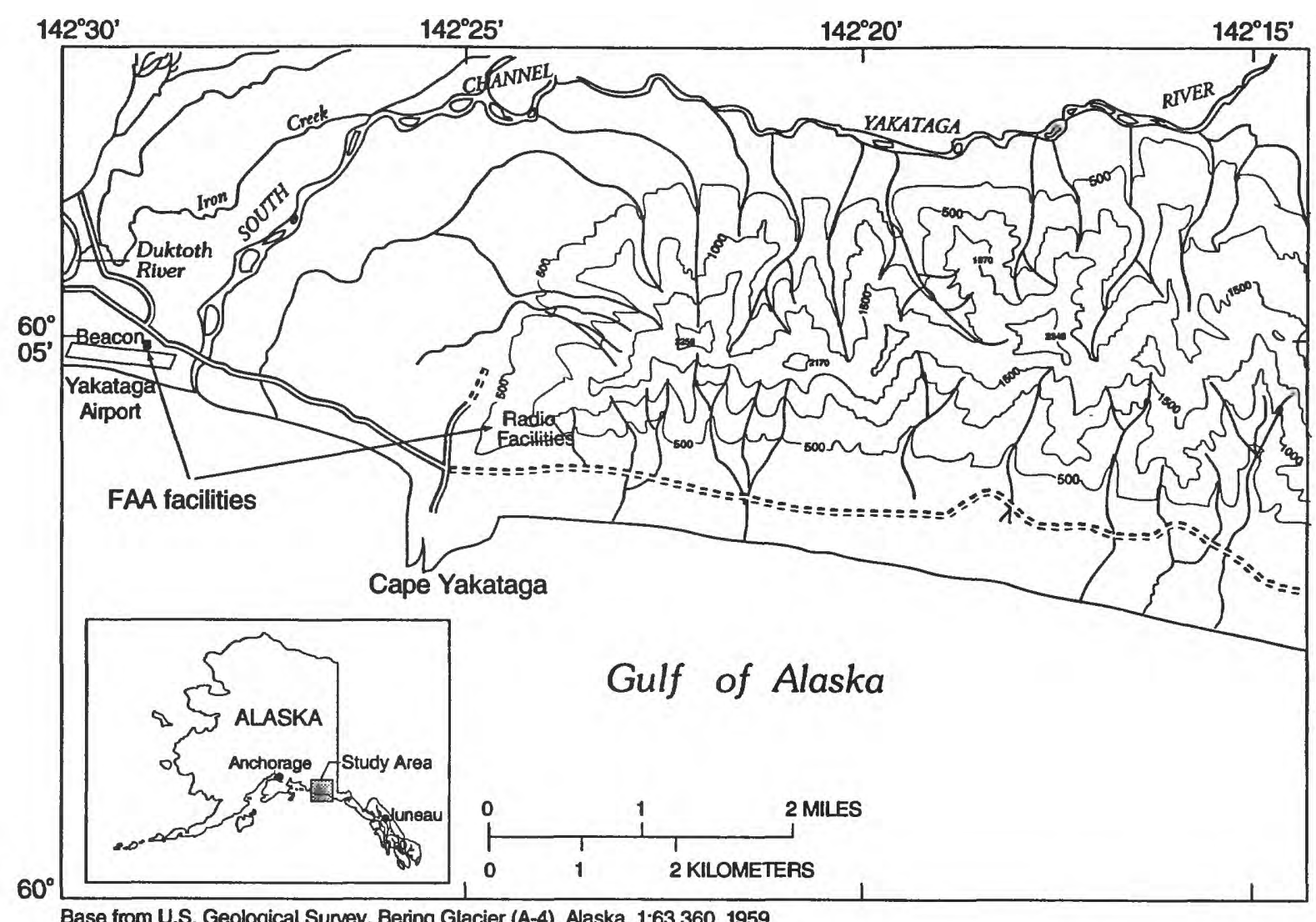

Base from U.S. Geological Survey, Bering Glacier (A-4), Aaska, 1:63,360, 1959

Figure 3. Location of Cape Yakataga, Alaska and the Federal Aviation Administration facilities

\section{Climate}

Cape Yakataga has a mean annual temperature of $4.4^{\circ} \mathrm{C}$. Temperatures range from a July mean maximum of $40.6^{\circ} \mathrm{C}$ to a January mean minimum of $-5.5^{\circ} \mathrm{C}$ (Leslie, 1989). Mean annual precipitation is about $2,580 \mathrm{~mm}$ and mean annual snowfall is about $2,700 \mathrm{~mm}$. Mean monthly and annual temperature, precipitation, and snowfall are summarized in table 5 (Leslie, 1989).

Table 5. Mean monthly and annual temperature, precipitation, and snowfall, Yakataga, Alaska, 1943-83. [Modified from Leslie (1989); ${ }^{\circ} \mathrm{C}$, degree Celsius]

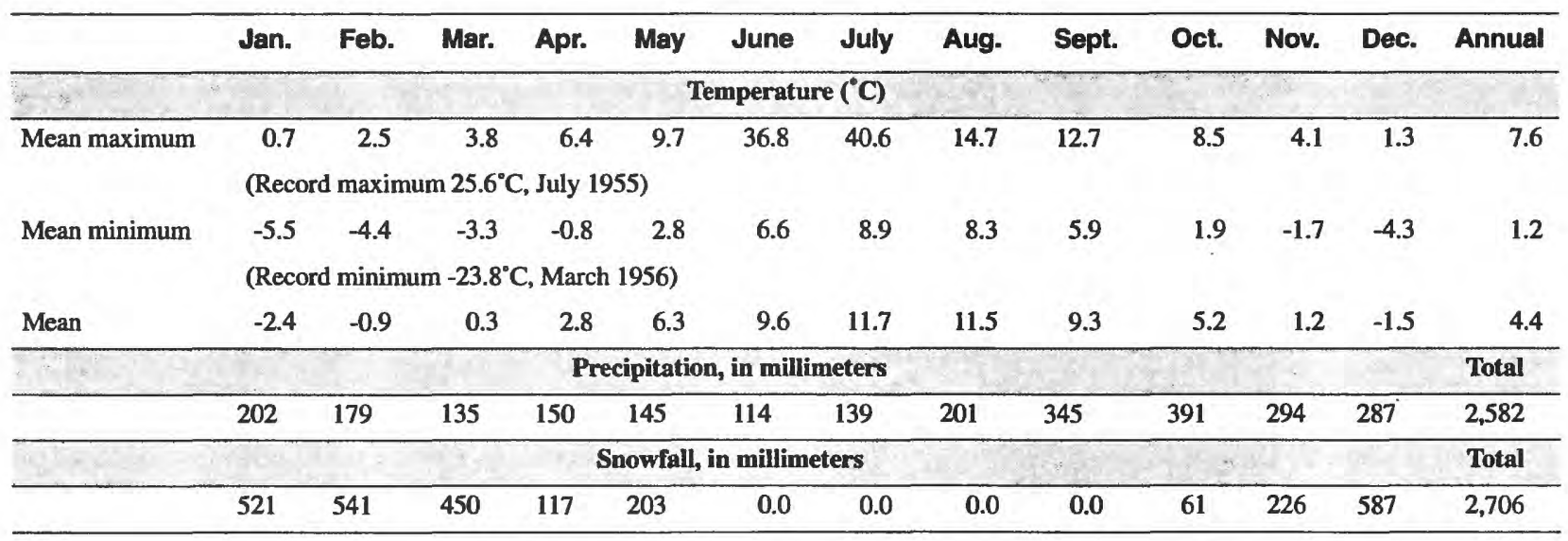




\section{Geology}

The bedrock underlying Cape Yakataga consists of sedimentary rocks of Miocene and Pliocene age (Miller, 1971; Winkler and Plafker, 1993). The rocks include concretionary and pyritic siltstone, claystone, and sandstone and subordinate, organic-rich shale, silty shale, and calcareous sandstone (Miller, 1971; Winkler and Plafker, 1993). Depth to bedrock is greater than $9 \mathrm{~m}$ below land surface (Miller, 1971). Surficial materials near Cape Yakataga are principally outwash alluvium of Quaternary age consisting of thick, extensive sand and gravel deposits that are at least 9-m thick (Miller, 1971). Soils in the area are of two principal types (Rieger and others, 1979). Soils developed on well-drained outwash consists of gravelly loam and silt loam. Organicrich soils are found in poorly drained low-lying areas and consist mostly of peat in various stages of decomposition (Rieger and others, 1979).

\section{Hydrology}

\section{Surface Water}

The South Channel of the Yakataga River, the Dukoth River, and Iron Creek are the principal freshwater bodies near the FAA facilities at Cape Yakataga (fig. 3). The South Channel of the Yakataga River passes due east of the airport, flows from northeast to southwest, and empties into the Gulf of Alaska. The Duktoth River passes due west of the facilities, flows from north to south, and also empties into the Gulf of Alaska. Iron Creek passes the airport about $1.5 \mathrm{~km}$ to the north and is a tributary of the Duktoth River (fig. 3). Surrounding the facilities are other unnamed tributaries of the Gulf of Alaska that originate in the Robinson Mountains. Mean annual runoff in the Cape Yakataga area is estimated to exceed $0.14\left(\mathrm{~m}^{3} / \mathrm{s}\right) / \mathrm{km}^{2}$ (B.B. Bigelow, U.S. Geological Survey, written commun., 1995).

\section{Ground Water}

Ground water near the FAA facilities at Cape Yakataga is found in the unconsolidated deposits of Quaternary age. A southward-sloping area of alluvial fans and outwash deposits, extending from the base of the Robinson Mountains to the coast, contains ground water (Rosenshein, 1988). On a regional scale, ground-water flow likely matches the local topography, flowing from the Robinson Mountains, south-southwestward to the coast. Locally, ground-water flow is generally towards drains such as rivers, streams, and ponds. Water was reached in a 8.5 meter-deep well at the FAA facilities between 4.5 and $7.5 \mathrm{~m}$ below land surface (Ecology and Environment Inc., 1992b). The availability of ground water from bedrock is unknown.

Recharge to the unconsolidated deposits primarily is from infiltration of precipitation and streamflow, and from subsurface inflow. Recharge is probably greatest when precipitation is high and streamflow is at or near maximum for the year, although the quantity of recharge to the groundwater system near Cape Yakataga is unknown. Ground water discharges from the unconsolidated deposits into springs, streams, and the Gulf of Alaska, and is lost through evapotranspiration and well withdrawal. Data are not available to determine the quantity of ground-water discharge. 


\section{Drinking Water}

Selkregg (1976) reports that a well is the primary drinking-water source for the community of Cape Yakataga. Ecology and Environment Inc. (1992b), however, reports that well water is not used by FAA personnel or by residents within $6.5 \mathrm{~km}$ of the FAA facilities. Drinking water is flown or hauled in with other supplies.

The South Channel of the Yakataga River, Duktoth River, Iron Creek, and untapped areas of the aquifer represent alternative drinking-water sources for residents near the Cape Yakataga FAA facilities. Data for these water resources are unavailable.

\section{GUSTAVUS}

\section{Location and Facility History}

Gustavus is a small community adjacent to the southern boundary of Glacier Bay National Park. It is about $80 \mathrm{~km}$ west of Juneau near the north end of Icy Strait at lat $58^{\circ} 25^{\prime}$ N., long $135^{\circ} 40^{\prime}$ W. (figs. 1 and 4 ). The Gustavus FAA facilities were first constructed as a military support airstrip during World War II. Some of these facilities were transferred to the State of Alaska in 1965 (Ecology and Environment Inc., 1992c). The FAA currently operates communication and navigation support facilities at or near the Gustavus Airfield. A detailed list of FAA owned and operated facilities at Gustavus and a list of potential sources of contamination can be found in an environmental compliance investigation report by Ecology and Environment Inc. (1992c).

\section{Climate}

Gustavus has a mean annual temperature of $4.9^{\circ} \mathrm{C}$. Temperatures range from a July mean maximum of $17.4{ }^{\circ} \mathrm{C}$ to a January mean minimum of $-5.9{ }^{\circ} \mathrm{C}$ (Leslie, 1989). Mean annual precipitation is about $1,370 \mathrm{~mm}$ and mean annual snowfall is about 1,790. Mean monthly and annual temperature, precipitation, and snowfall are summarized in table 6 (Leslie, 1989).

Table 6. Mean monthly and annual temperature, precipitation, and snowfall, Gustavus, Alaska, 1923-87. [Modified from Leslie (1989); ${ }^{\circ} \mathrm{C}$, degree Celsius]

\begin{tabular}{|c|c|c|c|c|c|c|c|c|c|c|c|c|c|}
\hline & Jan. & Feb. & Mar. & Apr. & May & June & July & Aug. & Sept. & Oct. & Nov. & Dec. & Annual \\
\hline & \multicolumn{13}{|c|}{ Temperature ( $\left.{ }^{\circ} \mathrm{C}\right)$} \\
\hline \multirow[t]{2}{*}{ Mean maximum } & 0.3 & 1.6 & 4.3 & 8.6 & 12.9 & 16.2 & 17.4 & 17.2 & 14.2 & 8.9 & 4.0 & 1.1 & 8.9 \\
\hline & \multicolumn{13}{|c|}{ (Record maximum $30.6^{\circ} \mathrm{C}$, August 1957) } \\
\hline \multirow[t]{2}{*}{ Mean minimum } & -5.9 & -5.4 & -3.4 & -0.2 & 3.1 & 6.4 & 8.7 & 7.8 & 5.4 & 2.5 & -2.1 & -4.7 & 1.0 \\
\hline & \multicolumn{13}{|c|}{ (Record minimum $-31.7^{\circ} \mathrm{C}$, January 1925 ) } \\
\hline \multirow[t]{3}{*}{ Mean } & -2.9 & -1.9 & 0.4 & 4.2 & 8.1 & 11.3 & 13.0 & 12.5 & 9.8 & 5.8 & 0.9 & -1.8 & 4.9 \\
\hline & \multicolumn{12}{|c|}{ Precipitation, in millimeters } & Total \\
\hline & 118 & 84 & 73 & 66 & 70 & 61 & 97 & 116 & 172 & 229 & 158 & 126 & 1,370 \\
\hline & \multicolumn{12}{|c|}{ Snowfall, in millimeters } & Total \\
\hline & 446 & 340 & 302 & 48 & 5 & 0.0 & 0.0 & 0.0 & 0.0 & 20 & 178 & 446 & 1,785 \\
\hline
\end{tabular}




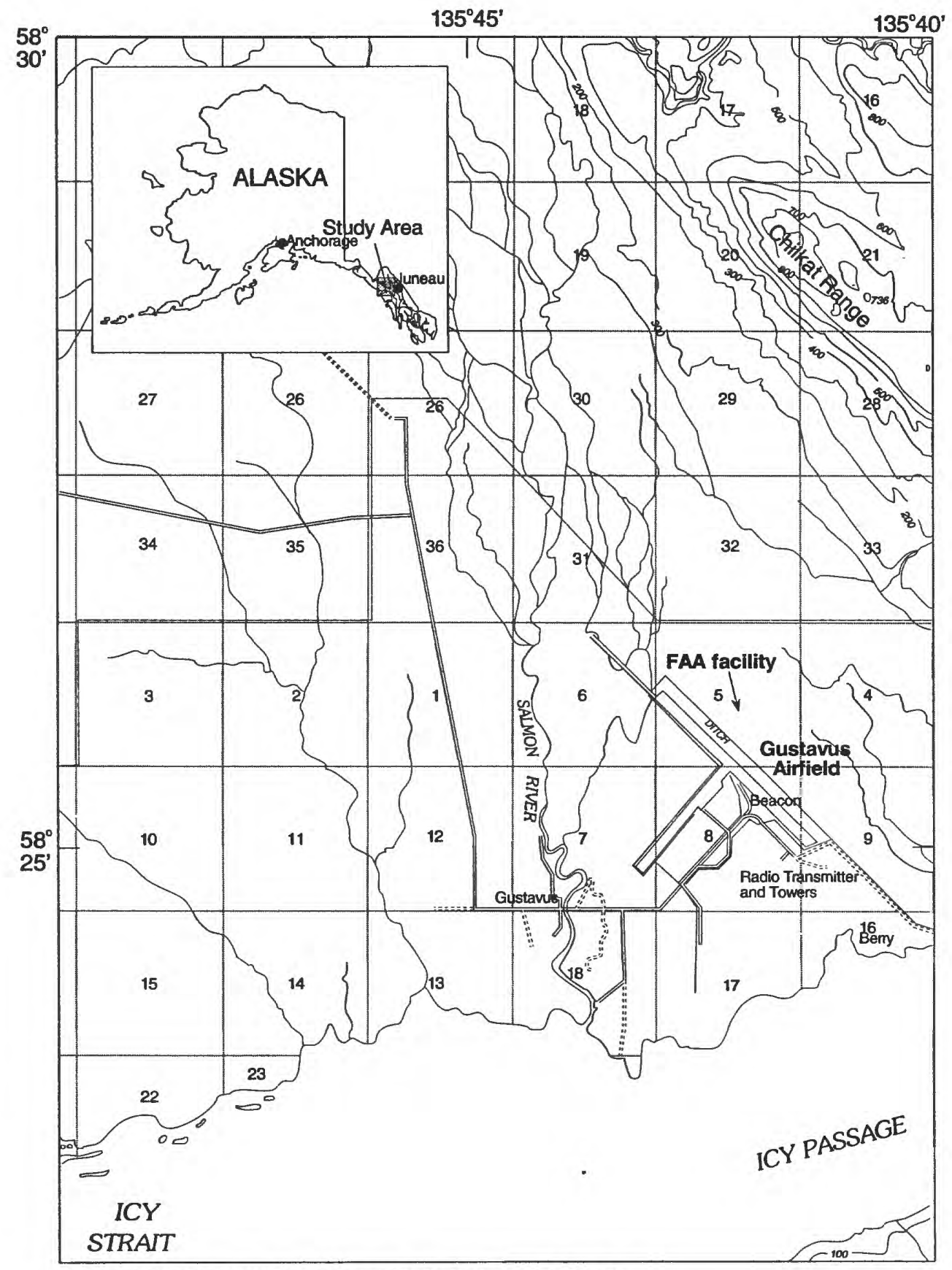

Base from U.S. Geological Survey, Juneau (B-6), Alaska, 1:63,360, 1948

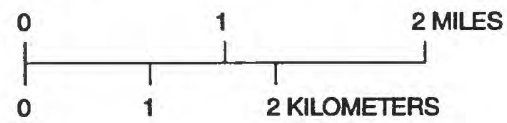

Figure 4. Location of Gustavus, Alaska and the Federal Aviation Administration facility. 


\section{Geology}

Bedrock is exposed northeast of Gustavus in the Chilkat Range and consists of sedimentary graywacke, mudstone, and turbidites of Silurian age, interbedded with lenses of limestone and conglomerate rocks. Grandiorite intrusions are common (Berg and Gehrels, 1992). Depth to bedrock near Gustavus is unknown. Unconsolidated surficial materials near Gustavus include alluvial and glacial deposits (Rieger and others, 1979). Moderately well-drained alluvial deposits are found along streams and rivers and consist of well-sorted silt, sand, and gravel. Glacial deposits consist of sand, silt, gravel, and boulders (Rieger and others, 1979). Organic-rich soils occupy areas near Gustavus where the water table is shallow and the land gradient is less than 1 percent (Rieger and others, 1979). The soils formed on glacial deposits near Gustavus are typically well drained and consist of 0.3 to $0.5 \mathrm{~m}$ of dark-gray stratified silt loam (Rieger and others, 1979).

\section{Hydrology}

\section{Surface Water}

The Salmon River and several small tributaries to Icy Strait are the principal freshwater bodies near the FAA facility at Gustavus (fig. 4). Hydrologic data for these bodies of water were not found. Gustavus is about $30 \mathrm{~m}$ above mean sea level and a gradual topographic gradient of about $5 \mathrm{~m} / \mathrm{km}$ directs runoff south towards Icy Strait. Average annual runoff near Gustavus is about $0.10\left(\mathrm{~m}^{3} / \mathrm{s}\right) / \mathrm{km}^{2}$ (Selkregg, 1976).

\section{Ground Water}

Ground water near Gustavus generally is present within alluvial and glacial materials. Individual wells reached water at depths ranging from 5 to $12 \mathrm{~m}$ below land surface (Appendix 3). A 17-meter-deep well was drilled near the FAA facility in September 1965 and water was reached at $6 \mathrm{~m}$ below land surface (Appendix 3). Drawdown in this well was $1.5 \mathrm{~m}$ after 24 hours of pumping at a rate of $1.9 \mathrm{~L} / \mathrm{s}$. Drawdown was $3 \mathrm{~m}$ after 24 hours of pumping at a rate of $4.4 \mathrm{~L} / \mathrm{s}$.

Ground water is recharged by infiltration of rainfall and the melting of snow. Ground-water flow is south to southwest toward Icy Strait. The presence of water in bedrock is unknown. Exposed bedrock north and east of Gustavus is dense and the occurrence of water in such rocks is unlikely.

\section{Drinking Water}

Ground water is the principal drinking-water source near Gustavus. Some residents, however, use surface-water sources (U.S. Bureau of Census, 1991). About 88 percent of the residents near Gustavus obtain their drinking water from individual wells, 10 percent use a single community well, and 2 percent use surface-water sources (U.S. Bureau of Census, 1991). The community well is within a 500-meter radius of the FAA facility and is completed to a depth of about $10 \mathrm{~m}$ below land surface. Between 1959 and 1968, ground-water samples were taken from at least six different wells near the FAA facility (Appendix 3), and major ions and water properties were analyzed. With the exception of iron, concentrations of measured constituents are within current U.S. Environmental Protection Agency (USEPA) regulations (table 7). 
Table 7. Concentrations of selected inorganic constituents in ground water near the FAA facility, Gustavus, Alaska

[mg/L, milligrams per liter]

\begin{tabular}{lcc}
\hline \multicolumn{1}{c}{ Constituent (or property) } & $\begin{array}{c}\text { USEPA } \\
\text { Drinking-water regulation } \\
(\mathrm{mg} / \mathrm{L})\end{array}$ & $\begin{array}{c}\text { Concentration range in } \\
\text { ground water at the FAA } \\
\text { facility (mg/L) }\end{array}$ \\
\hline Chloride (Cl) & 250 & $1.6-35$ \\
Iron (Fe) & 0.3 & $0.02-4.0$ \\
Sulfate $\left(\mathrm{SO}_{4}\right)$ & 250 & $11-53$ \\
Fluoride (F) & 2 & $0.0-0.1$ \\
Total dissolved solids & 500 & $232-322$ \\
$\mathrm{pH}$ (units) & $6.5-8.5$ & $6.7-8.2$ \\
\hline
\end{tabular}

The Salmon River and several small Icy Strait tributaries may be alternative drinking-water sources for residents near the FAA facility at Gustavus. However, quantity and quality data are not available for these water bodies.

\section{HAINES}

\section{Location and Facility History}

Haines is a small community at the northern end of Lynn Canal between the Chilkoot and Chilkat Inlets. It is about $150 \mathrm{~km}$ northwest of Juneau near lat $59^{\circ} 15^{\prime} \mathrm{N}$., long $135^{\circ} 29^{\prime} \mathrm{W}$. (figs. 1 and 5). The FAA involvement at Haines began in 1948, and the FAA currently operates navigation and communication aids. A detailed list of FAA owned and operated facilities at Haines, and a list of potential sources of contamination can be found in an environmental compliance investigation report by Ecology and Environment Inc. (1994).

\section{Climate}

Haines has a mean annual temperature of $5.3{ }^{\circ} \mathrm{C}$. Temperatures range from a July mean maximum of $19.2{ }^{\circ} \mathrm{C}$ to a January mean minimum of $-6.7^{\circ} \mathrm{C}$ (Leslie, 1989). Mean annual precipitation is about $1,300 \mathrm{~mm}$ and mean annual snowfall is about 3,360 mm. Mean monthly and annual temperature, precipitation, and snowfall are summarized in table 8 (Leslie, 1989). 


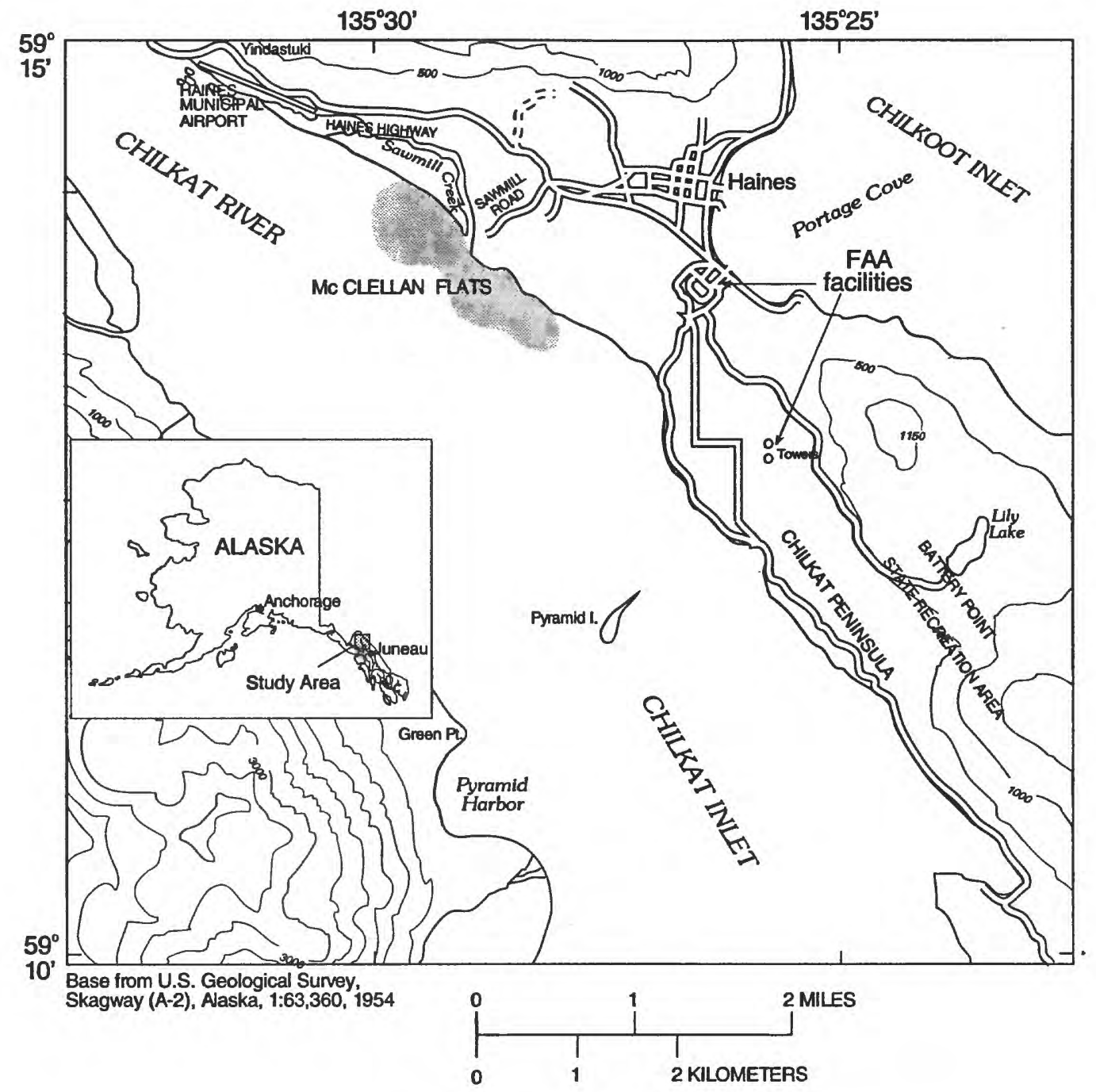

Figure 5. Location of Haines, Alaska and the Federal Aviation Administration facilities.

Table 8. Mean monthly and annual temperature, precipitation, and snowfall, Haines, Alaska, 1973-87. [Modified from Leslie (1989); ${ }^{\circ} \mathrm{C}$, degree Celsius]

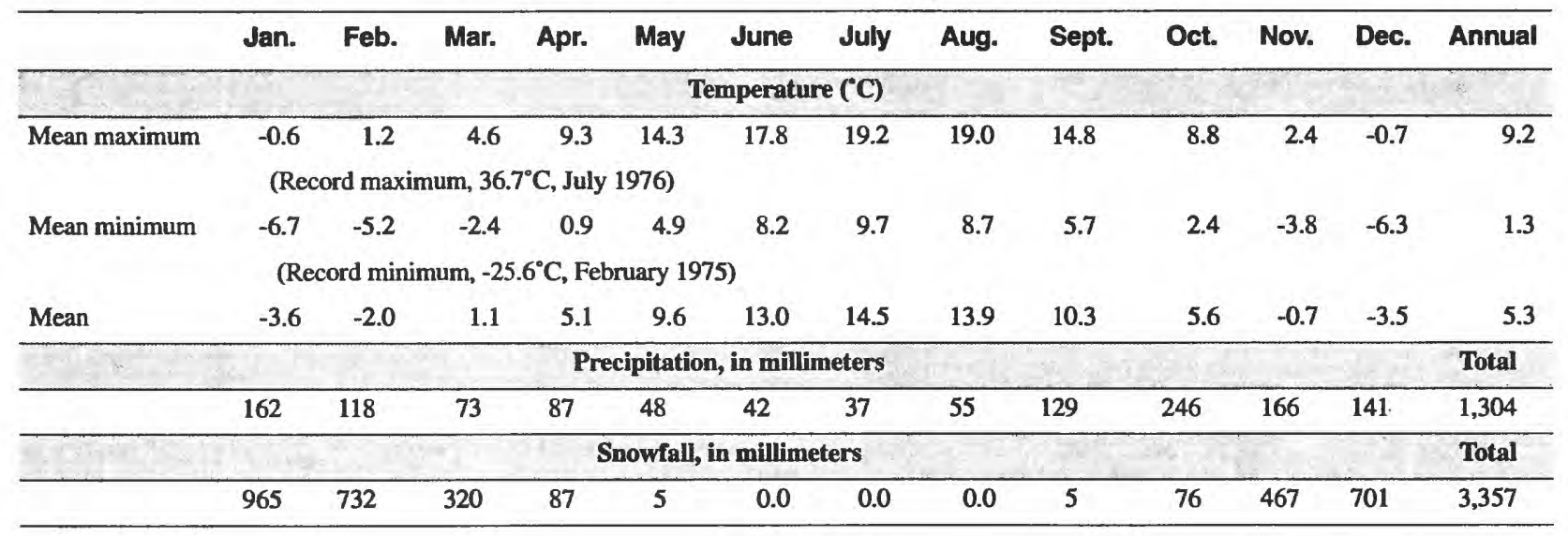




\section{Geology}

Metamorphosed bedrock of Mesozoic age underlies the Haines area and includes intrusive rocks of Cretaceous age and basaltic rocks of Triassic age (Berg and Gehrels, 1992; McConaghy, 1970). The intrusive rocks consist of magnetite-bearing hornblende, metabasalt, pyroxenite, tonalite, and diorite. At its deepest point, bedrock is about $180 \mathrm{~m}$ below land surface. (McConaghy, 1970).

Unconsolidated surficial materials in the Haines area include beach deposits, marine clay, alluvial deposits, and glacial outwash (McConaghy, 1970). The most common surficial deposit near the FAA facility is glacial outwash which consists of gravel, sand, silt, and clay that is at least $1 \mathrm{~m}$ thick (McConaghy, 1970). A driller's log of a 34-meter-deep well in the Haines area indicates that soil, silty clay, and "rock" occur to $4 \mathrm{~m}$; layered clay and gravel to $16 \mathrm{~m}$; coarse gravel and boulders to $22 \mathrm{~m}$; blue-black clay to $25 \mathrm{~m}$; clay and fine sand to $26 \mathrm{~m}$; and mixed gravel and clay to $34 \mathrm{~m}$ below land surface (Appendix 4). Additional well logs are given in Appendix 4.

Two soil types are present near the FAA facilities (Rieger and others, 1979; Environmental Services Ltd, 1979). Soils found in areas of steep relief are typically well drained and acidic (Rieger and others, 1979). These soils are characterized by a thin, gray surface layer over black-toreddish brown subsurface layers (Rieger and others, 1979). Organic-rich soils are formed in poorly drained low-lying areas and consist of partially to highly decomposed peat (Rieger and others, 1979).

\section{Hydrology}

\section{Surface Water}

Freshwater resources near the Haines FAA facilities include Sawmill Creek, the Chilkat River, and Lily Lake (fig. 5). Sawmill Creek passes $2 \mathrm{~km}$ northwest of the FAA facilities and flows from northwest to southeast draining into the Chilkat River. Low flow of the creek during winter months is estimated to be about $0.3 \mathrm{~m}^{3} / \mathrm{s}$ (McConaghy, 1970; Bugliosi, 1988).

The Chilkat River passes the FAA facilities less than $2 \mathrm{~km}$ to the east and flows from northwest to southeast. The river represents the largest drainage within southeastern Alaska. Flow of the Chilkat River near Klukwan, about $30 \mathrm{~km}$ north of Haines, was recorded from 1959 to 1961 at USGS stream-gaging station 15056500, Chilkat River near Klukwan. From June to August, mean flow of the river is greater than $200 \mathrm{~m}^{3} / \mathrm{s}$, and from January to March, mean flow is less than $13 \mathrm{~m}^{3} / \mathrm{s}$ (fig. 6, table 9; U.S. Geological Survey, 1962). The Chilkat River drains an area of about $2,000 \mathrm{~km}^{2}$ upstream from Klukwan.

Table 9. Mean monthly flow at 15056500, Chilkat River at Klukwan, water years 1959-61 [Values in cubic meters per second]

\begin{tabular}{lcccccccccccc}
\hline & Oct. & Nov. & Dec. & Jan. & Feb. & Mar. & Apr. & May & June & July & Aug. & Sept. \\
\hline Mean & 47.2 & 28.4 & 23.2 & 12.6 & 7.7 & 8.6 & 21.6 & 112 & 235 & 256 & 209 & 94.0 \\
Maximum & 51.7 & 30.7 & 24.4 & 12.7 & 8.22 & 9.46 & 24.9 & 132 & 239 & 282 & 264 & 109 \\
Minimum & 42.7 & 26.1 & 22.2 & 12.5 & 7.22 & 7.85 & 18.4 & 92.4 & 231 & 229 & 162 & 72.6 \\
\hline
\end{tabular}




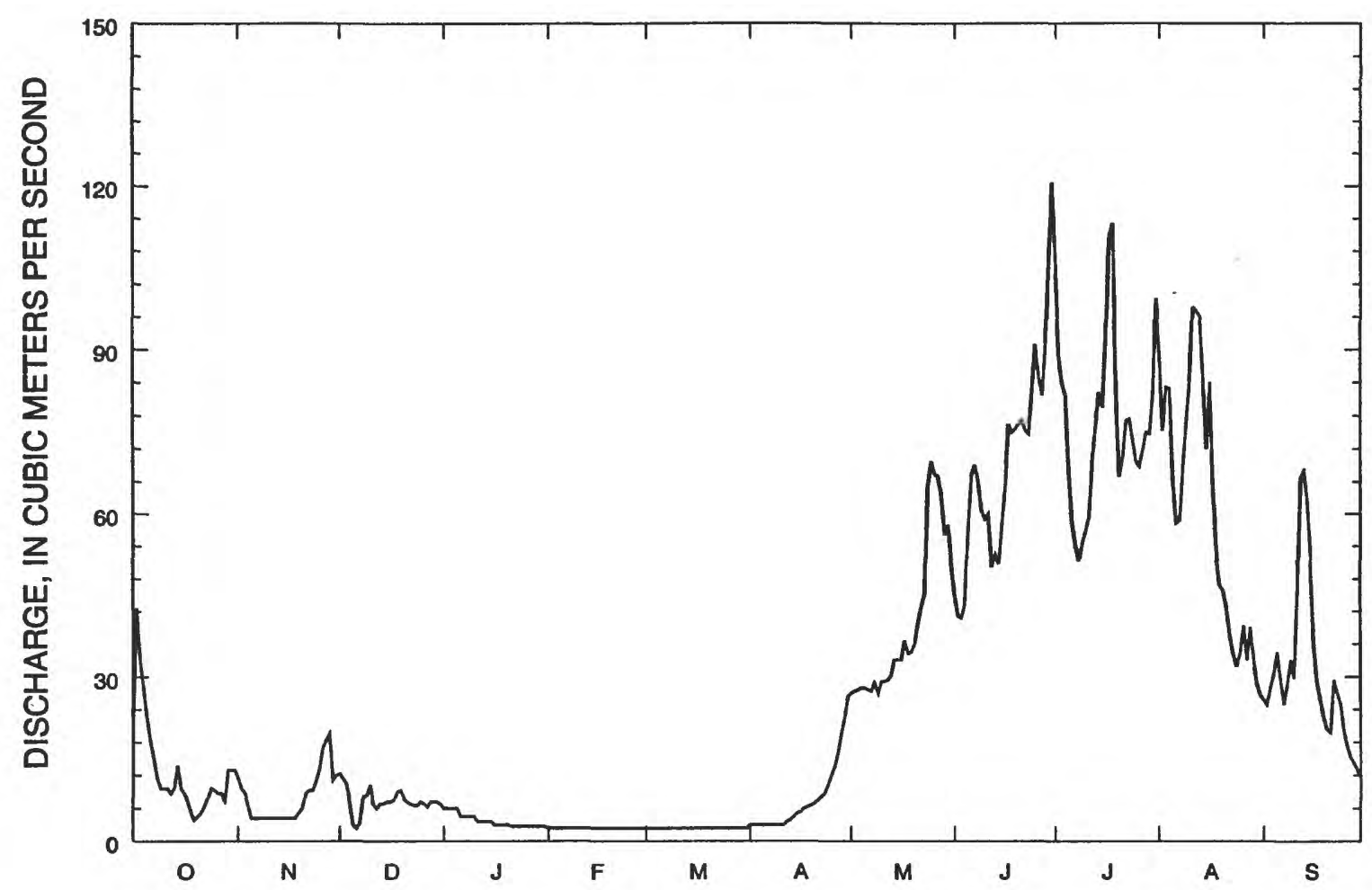

Figure 6. Daily mean discharge of the Chilkat River near Klukwan, water year 1960.

Lily Lake is about $2 \mathrm{~km}$ southeast of the FAA facilities at an elevation about $75 \mathrm{~m}$ above mean sea level. The lake is the principal drinking-water supply for the Haines community. Lily Lake has a surface area of about $0.13 \mathrm{~km}^{2}$ and supplies about 3 million L/d to the municipal system (Environmental Service Ltd., 1979).

Near the FAA facility, a southeasterly topographic gradient of about $75 \mathrm{~m} / \mathrm{km}$ generally causes runoff to flow towards tributaries that drain to the Chilkat River. Annual runoff rates in the area are about $0.2\left(\mathrm{~m}^{3} / \mathrm{s}\right) / \mathrm{km}^{2}$ (Selkregg, 1976).

\section{Ground Water}

McConaghy (1970) describes the ground-water system in the Haines area. Sand and gravel constitute the unconfined aquifers; clay and silty sand constitute the confining beds. Data on ground-water availability in the Haines area are given in Appendix 4. Ground water is available from alluvium south of the Haines Highway and Sawmill Road (fig. 6). These gravelly deposits, however, are not continuous. The wetland west of Sawmill Road and the raised beach deposits near Portage Cove also have ground-water potential. Wetland areas, however, are subject to periodic tidewater flooding and are unlikely to contain significant amounts of freshwater. The bedrock in upland areas near Haines is exposed or is near the land surface and probably is not a reliable source of ground water. 
Several wells between 3 and 79-m deep were drilled in the Haines area (Appendix 4). Water was reached at depths between 1 and $12 \mathrm{~m}$ below the land surface. Upland slopes northwest and southwest of the City of Haines are the principal recharge areas (McConaghy, 1970). Most of the ground-water movement is through the valley to the west of the city. Ground water discharges into small streams, wetland areas, the Chilkat River, Chilkat Inlet, and Portage Cove (McConaghy, 1970).

\section{Drinking Water}

Lily Lake is the principal drinking-water source near Haines (fig. 5). The city of Haines owns and operates the water-treatment and distribution facility that provides water to all users within the city limits (Environmental Services, Ltd., 1979; U.S. Bureau of Census, 1991). A 15-centimeter transmission line connects the water supply at Lily Lake to a water-treatment plant and two water tanks with a combined capacity of about 660,000 L (Environmental Services, Ltd., 1983). Water treatment consists of filtration followed by chlorination. Average demand for water in Haines is about 490,000 L/d. Peak demand during the summer averages $820,000 \mathrm{~L} / \mathrm{d}$. Lily Lake is an abundant water source, and the capacity of the treatment plant could accommodate a 100-percent increase in population (Environmental Services, Ltd., 1979). The water in Lily Lake is reportedly of adequate quality (McConaghy, 1970). Analyses indicated a dissolved-iron concentration of $0.01 \mathrm{mg} / \mathrm{L}$; a chloride concentration of $2.5 \mathrm{mg} / \mathrm{L}$; a hardness as $\mathrm{CaCO}_{3}$ of $98 \mathrm{mg} / \mathrm{L}$; and a total dissolved-solids concentration of $133 \mathrm{mg} / \mathrm{L}$.

Ground water represents an alternative drinking-water source near the Haines FAA facilities. Ground water is found in the glacial outwash south of the Haines Highway and Sawmill Road, the wetland west of Sawmill Road, and the raised beach deposits near Portage Cove (McConaghy, 1970). With the exception of iron and chloride, major ions and water properties are within current USEPA and Alaska Department of Environmental Conservation (ADEC) drinking-water regulations (table 10; Appendix 5; ADEC, 1995). A well near McClellan Flats contained high concentrations of chloride, probably from naturally occurring salt water (McConaghy, 1970).

Table 10. Concentrations of selected inorganic constituents in ground water near Haines, Alaska [mg/L, milligrams per liter]

\begin{tabular}{lcc}
\hline Constituent (or property) & $\begin{array}{c}\text { USEPA } \\
\text { drinking-water regulation } \\
(\mathrm{mg} / \mathrm{L})\end{array}$ & $\begin{array}{c}\text { Concentration range in ground } \\
\text { water (mg/L) }\end{array}$ \\
\hline Chloride (Cl) & 250 & $2.8->250$ \\
Iron (Fe) & 0.3 & $0.0-3.2$ \\
Sulfate $\left(\mathrm{SO}_{4}\right)$ & 250 & $13-99$ \\
Fluoride (F) & 2 & $0.0-0.6$ \\
Total dissolved solids & 500 & $89-268$ \\
$\mathrm{pH}$ (units) & $6.5-8.5$ & $7.3-8.1$ \\
\hline
\end{tabular}




\section{BIORKA ISLAND}

\section{Location and Facility History}

Biorka Island is a small, circular island in Sitka Sound of the western Necker Islands. It is about $175 \mathrm{~km}$ southwest of Juneau near lat $56^{\circ} 51^{\prime} \mathrm{N}$., long $135^{\circ} 31^{\prime}$ W. (figs. 1 and 7). The FAA activities on Biorka Island began in 1951 when an operating agreement was signed with the United States Coast Guard (USCG). The FAA facilities currently include communication and navigation aids. A detailed list of FAA facilities on Biorka Island and a list of potential sources of contamination can be found in an environmental compliance investigation report by Ecology and the Environment Inc. (1992d).

\section{Climate}

Biorka Island has a mean annual temperature of $6.5^{\circ} \mathrm{C}$. Temperatures range from an August mean maximum of $16.8^{\circ} \mathrm{C}$ to a January mean minimum of $-2.9^{\circ} \mathrm{C}$ (Leslie, 1989). Mean annual precipitation is about $2,400 \mathrm{~mm}$ and mean annual snowfall is about $500 \mathrm{~mm}$. Mean monthly and annual temperature, precipitation, and snowfall are summarized in table 11 (Leslie, 1989).

Table 11. Mean monthly and annual temperature, precipitation, and snowfall, Biorka Island, Alaska, 1972-79.

[Modified from Leslie (1989); ${ }^{\circ} \mathrm{C}$, degree Celsius]

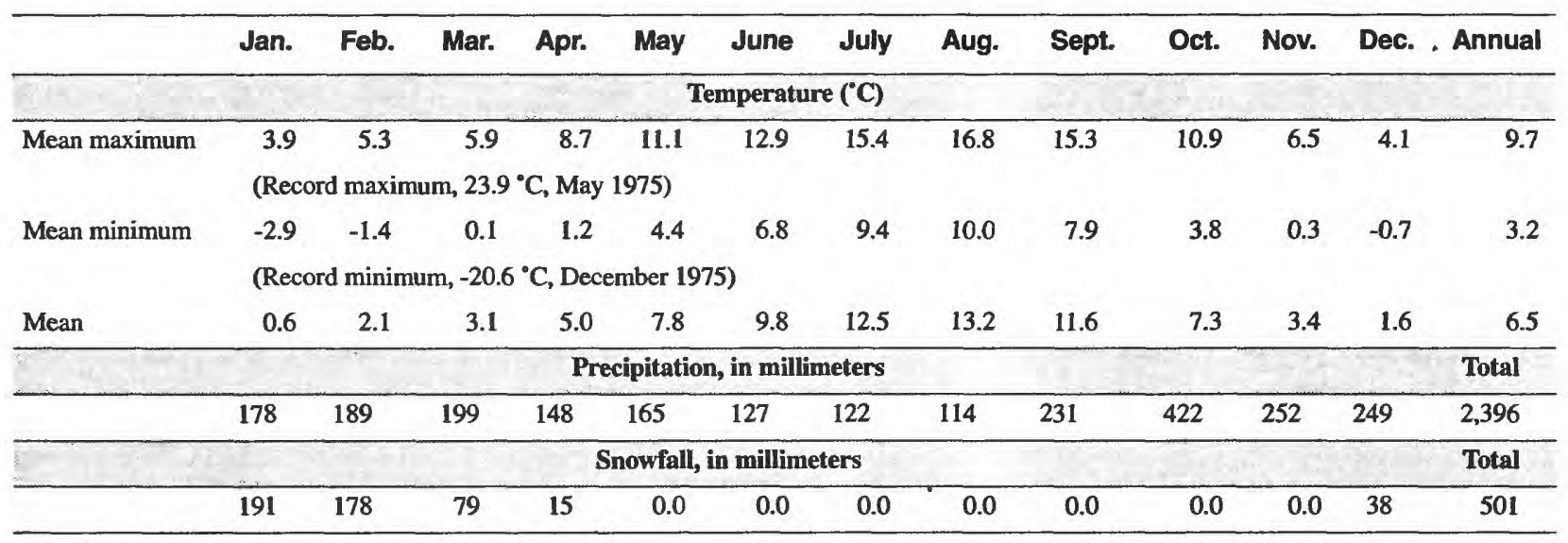

\section{Geology}

Bedrock on Biorka Island consists principally of dark-gray, medium- to thick-bedded, feldspathic, lithic, and arkosic graywacke, with lesser amounts of argillite, conglomerate, and chert (James Riehle, U.S. Geological Survey, oral commun., 1995; Berg and Gehrels, 1992). Surficial deposits on Biorka Island are mainly the products of volcanic eruptions (Rieger and others, 1979). These deposits consist mainly of ash and fine pumice and typically are 0.06 to $0.08 \mathrm{~m}$ thick (James Riehle, U.S. Geological Survey, oral commun., 1995). 


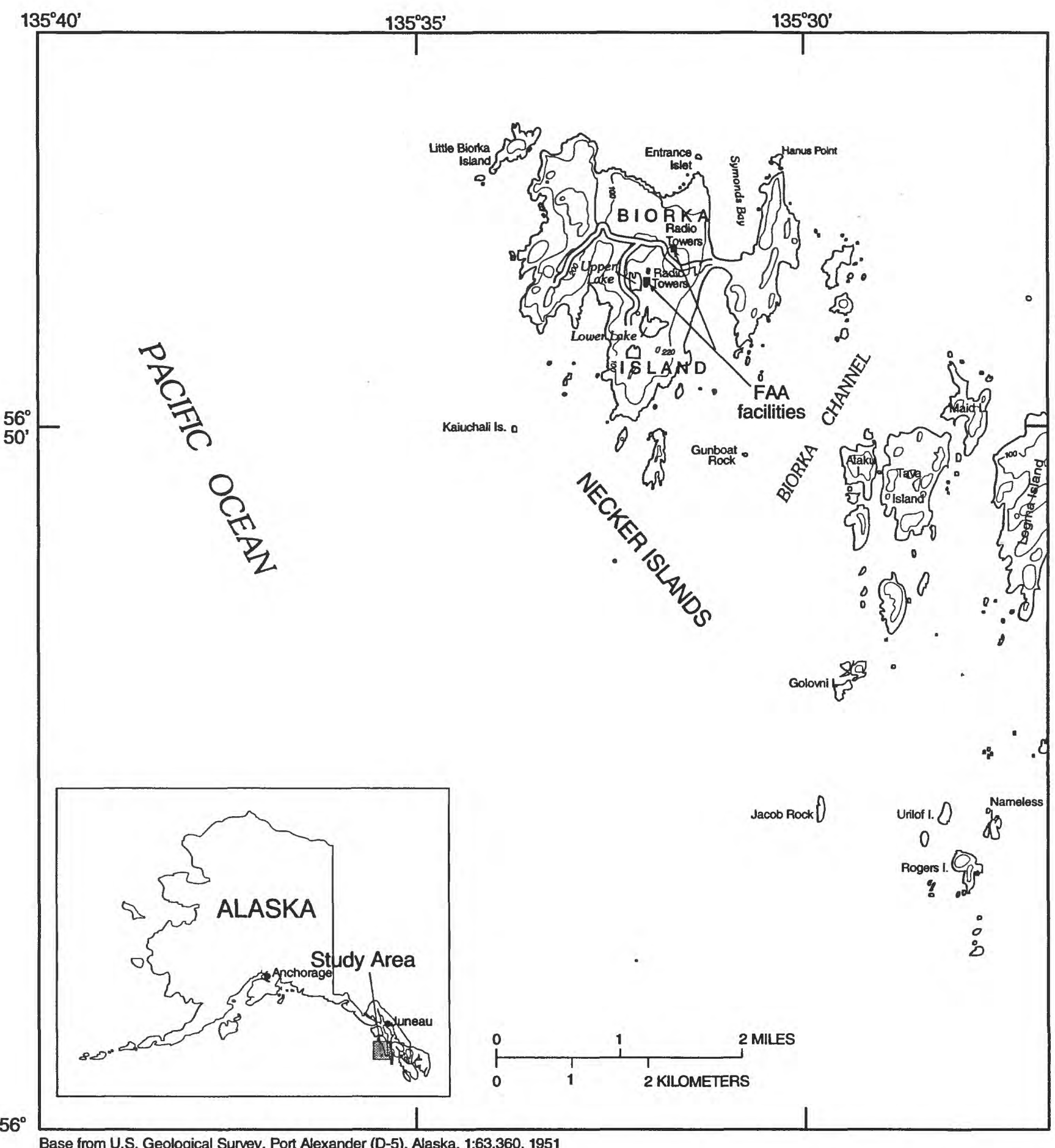

Base from U.S. Geological Survey, Port Alexander (D-5), Alaska, 1:63,360, 1951

Figure 7. Location of Biorka Island, Alaska and the Federal Aviation Administration facilities. 


\section{Hydrology}

\section{Surface Water}

Upper and Lower Lakes compose Biorka Island's principal freshwater resources (fig. 7). Upper Lake is within $800 \mathrm{~m}$ of several FAA facilities, and Lower Lake is about $400 \mathrm{~m}$ south of Upper Lake (fig. 7). Small, intermittent streams may occur during abundant rainfall or spring thaw. The FAA facilities near the middle of the island are about $60 \mathrm{~m}$ in elevation. From these facilities to the coast, the land surface drops about $75 \mathrm{~m} / \mathrm{km}$. Low-lying areas covering the island form a single drainage basin that is about $1.5 \mathrm{~km}^{2}$ in area. Mean annual runoff on the island is estimated at $0.15\left(\mathrm{~m}^{3} / \mathrm{s}\right) / \mathrm{km}^{2}$ (B.B Bigelow, U.S. Geological Survey, written commun., 1995).

\section{Ground Water}

Ground-water data for Biorka Island are scarce. Water from two wells within a 10-kilometer radius of the FAA facilities was once used for purposes other than drinking (Appendix 5). The depths of these wells and water levels are unknown. A well drilled by Ecology and Environment Inc. (1992d) reached water at a depth of about $0.2 \mathrm{~m}$ below land surface. The availability of ground water from bedrock on Biorka Island is unknown.

\section{Drinking Water}

Lower Lake is the principal drinking-water source on Biorka Island and is used by seasonal residents (fig. 7). The water is not currently used by FAA personnel. The quality and quantity of water in Lower Lake is unknown. Drinking water for the FAA facilities is flown or hauled in with other supplies. Shallow lakes, including Upper Lake, small streams, and ground water represent alternative drinking-water sources for Biorka Island. However, the quality and quantity of these resources are unknown.

\section{BIG LEVEL ISLAND}

\section{Location and Facility History}

Big Level Island is an uninhabited, circular island about $2 \mathrm{~km}$ in diameter. It is in Sumner Strait, $40 \mathrm{~km}$ south of Petersburg and $30 \mathrm{~km}$ west of Wrarigell, at lat $56^{\circ} 28^{\prime} \mathrm{N}$., long $133^{\circ} 05^{\prime} \mathrm{W}$. (figs. 1 and 8). The FAA facility on Big Level Island was constructed in 1964. The facility includes airway navigation and communication aids. The facility is currently maintained by FAA personnel stationed in Wrangell who visit the site once a month. A detailed description of the FAA facility on Big Level Island and a list of potential sources of contamination can be found in an environmental compliance investigation report by Ecology and Environment Inc. (1992e).

\section{Climate}

Big Level Island has a mean annual temperature of $6.3^{\circ} \mathrm{C}$. Temperatures range from an August mean maximum of $17.3{ }^{\circ} \mathrm{C}$ to a January mean minimum of $-3.3{ }^{\circ} \mathrm{C}$ (Leslie, 1989). Mean annual precipitation is about $1,740 \mathrm{~mm}$ and mean annual snowfall is about $1,160 \mathrm{~mm}$. Mean monthly and annual temperature, precipitation, and snowfall are summarized in table 12 (Leslie, 1989). 


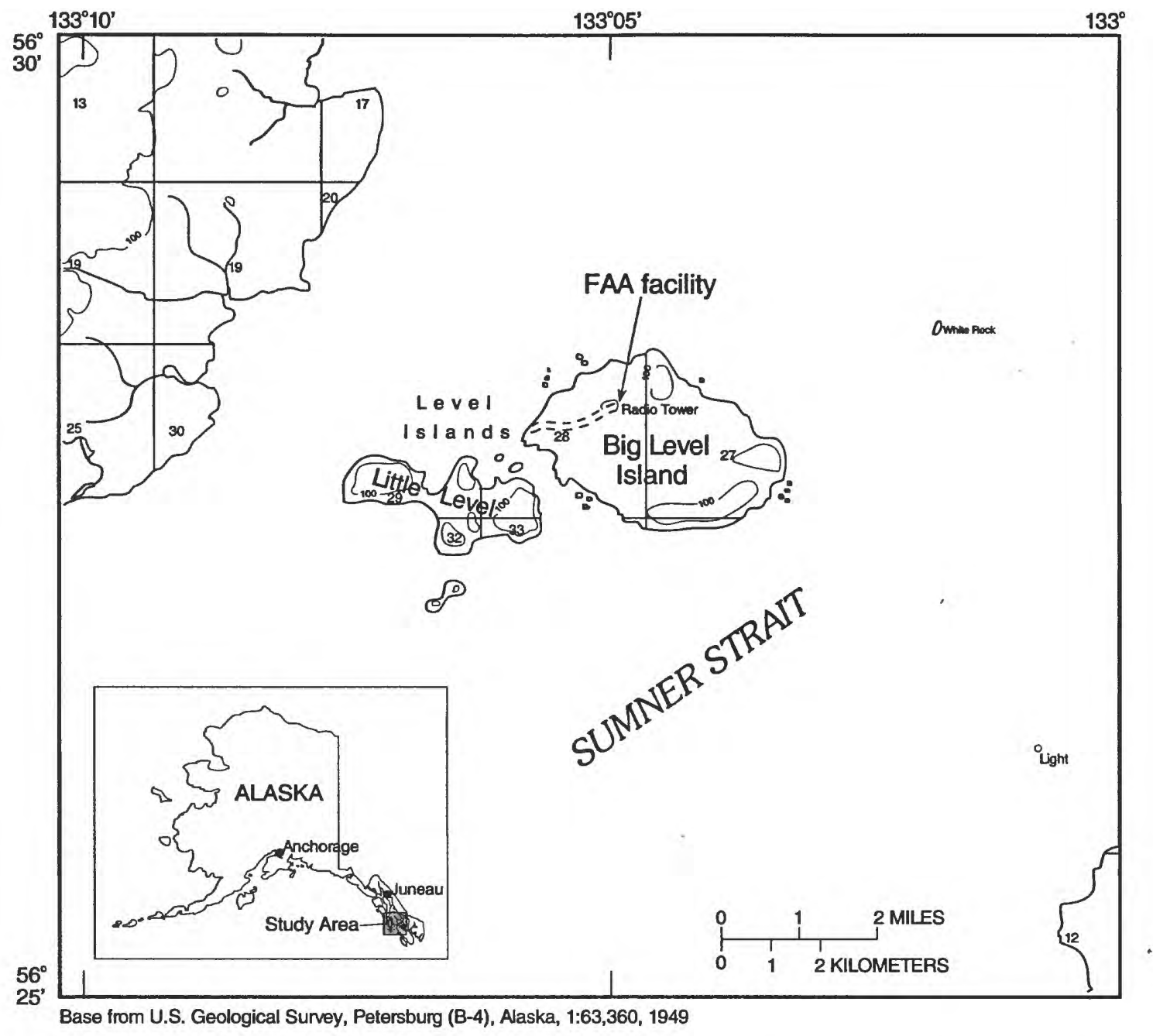

Figure 8. Location of Big Level Island, Alaska and the Federal Aviation Administration facility.

Table 12. Mean monthly and annual temperature, precipitation, and snowfall, Big Level Island, Alaska, 1973-78. [Modified from Leslie (1989); ${ }^{\circ} \mathrm{C}$, degree Celsius]

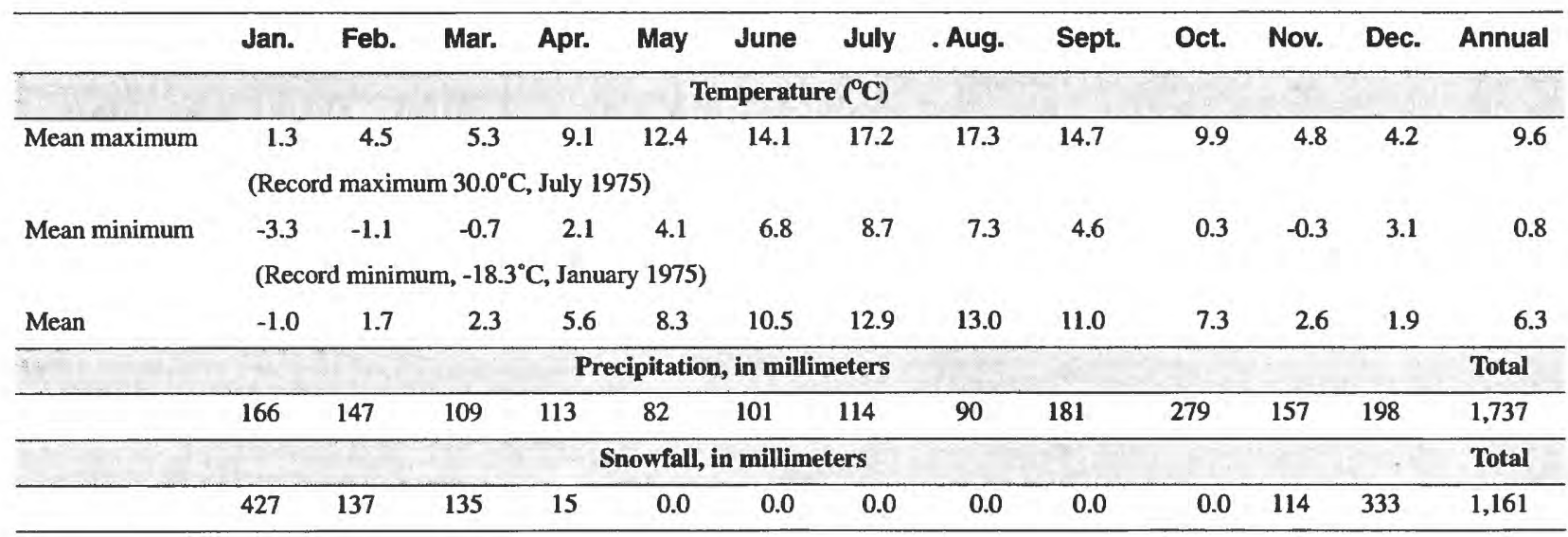




\section{Geology}

Big Level Island is underlain by marine sedimentary rocks, primarily graywackes and mudstones. Some andesitic to basaltic volcanic rocks and granitic intrusions also are present (Berg and Gehrels, 1992). Bedrock is exposed at low tide along the perimeter of the island (U.S. Fish and Wildlife Service, 1989). Inland, bedrock typically is less than $3 \mathrm{~m}$ below land surface. Surficial deposits on Big Level Island are principally till consisting of gravel and boulders in a sandy silt matrix (U.S. Fish and Wildlife Service, 1989).

\section{Hydrology}

\section{Surface and Ground Water}

Although no large rivers exist on Big Level Island, freshwater wetlands and small streams are common. Poorly drained wetlands occur in areas of shallow relief where small streams converge (U.S. Fish and Wildlife Service, 1989). Elevations on the island do not exceed $30 \mathrm{~m}$. Drainage on the island is toward the coast.

Ground-water data for Big Level Island are scarce. Some ground water is available at depths less than $3 \mathrm{~m}$ below land surface (Ecology and Environment Inc., 1992e). Currently, ground water is used only as a nonpotable water source on the island (Ecology and Environment Inc., 1992e).

\section{Drinking Water}

Surface water and ground water are not currently used as drinking-water sources on Big Level Island. Drinking water is shipped in from an outside source. Freshwater wetlands, small streams, and ground water represent alternative drinking-water sources on Big Level Island; however, the quality and quantity of these sources are unknown. Natural water sources on the island support large deer and other wildlife populations indicating the potential for acceptable drinking water (Doerr and Sandburg, 1986).

\section{ANNETTE ISLAND}

\section{Location and Facility History}

Annette Island is about $35 \mathrm{~km}^{2}$ in size and is at the southern end of Southeast Alaska near the Canadian border. It is about $25 \mathrm{~km}$ south of Ketchikan near lat $55^{\circ} 02^{\prime} \mathrm{N}$., long $131^{\circ} 34^{\prime} \mathrm{W}$. (figs. 1 and 9). The Metlakatla Peninsula extends west-southwest of the island. The village of Metlakatla is near the northern end of the peninsula. The FAA operations on Annette Island began in 1948 when air-navigation facilities were constructed there. Currently, the FAA facilities include air navigation and communication aids concentrated at the airport. Facility maintenance is carried out by FAA personnel stationed in Ketchikan. A detailed list of FAA facilities on Annette Island and a list of potential sources of contamination can be found in an environmental compliance investigation report by Ecology and Environment Inc. (1992f). 


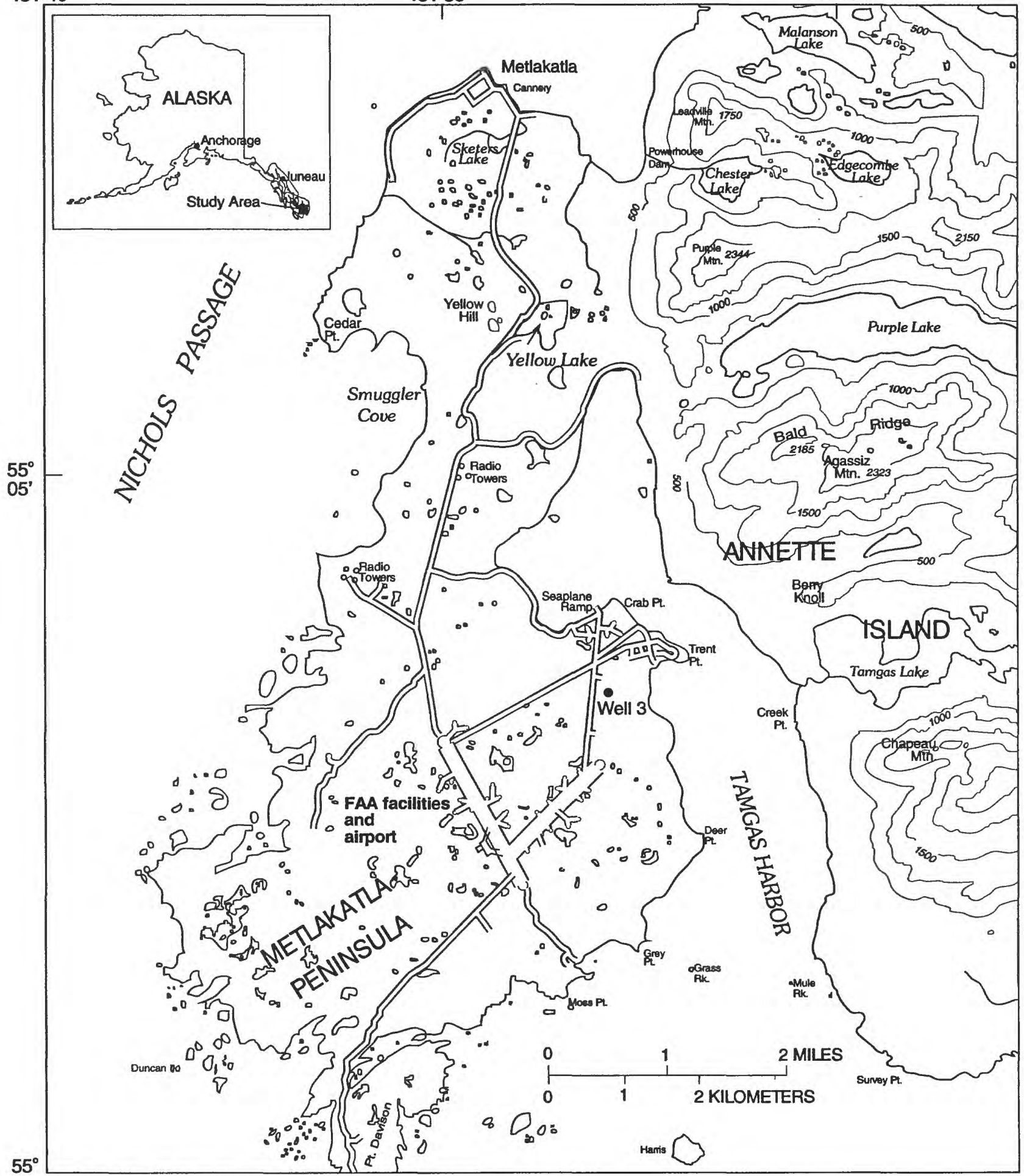

Base from U.S. Geological Survey, Ketchikan (A-5), Alaska, 1:63,360, 1955

Figure 9. Location of Annette Island, Alaska and the Federal Aviation Administration facilities. 


\section{Climate}

Annette Island has a mean annual temperature of $7.6^{\circ} \mathrm{C}$. Temperatures range from an August mean maximum of $18.0{ }^{\circ} \mathrm{C}$ to a January mean minimum of $-1.7^{\circ} \mathrm{C}$ (Leslie, 1989). Mean annual precipitation is about $2,820 \mathrm{~mm}$ and mean annual snowfall is about $1,320 \mathrm{~mm}$. Mean monthly and annual temperature, precipitation, and snowfall are summarized in table 13 (Leslie, 1989).

Table 13. Mean monthly and annual temperature, precipitation, and snowfall, Annette Island, Alaska, 1949-87.

[Modified from Leslie (1989); 'C, degree Celsius]

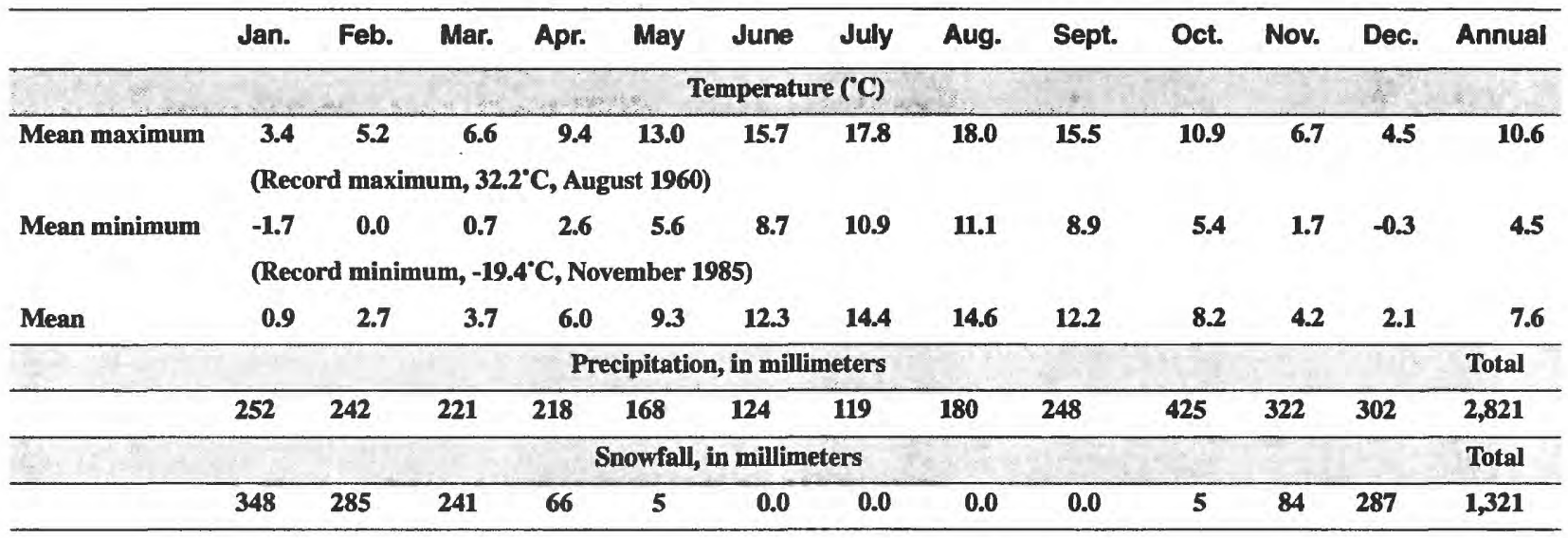

\section{Geology}

The FAA facilities on Annette Island are situated on a section of the island known as the Metlakatla Peninsula. Bedrock underlying the peninsula consists of deformed and metamorphosed volcanic rocks and clastic sedimentary rocks of Ordovician to Silurian age. Volcanic rocks consist of greenschist and greenstone. Sedimentary rocks are intruded by diorite, quartz diorite, and bodies of magnetite-bearing hornblende (Marcher, 1971a; Yehle, 1977; Berg and Gehrels, 1992). Most of the Metlakatla Peninsula was sheared flat by past glaciation (Yehle, 1977). The exception is an outcrop of resistant dunite known as Yellow Hill, about $4 \mathrm{~km}$ north of the FAA facilities. Depth to bedrock ranges from $15 \mathrm{~cm}$ to about $9 \mathrm{~m}$ below the land surface.

The principal surficial deposits found on Annette Island are beach sand, alluvium, and till (Marcher, 1971b). Beach deposits consisting of sand and gravel along the coast can be as much as $300 \mathrm{~m}$ wide and $10 \mathrm{~m}$ thick. Alluvial deposits on the island include stratified gravel, sand, and silt. These deposits are between 1.5 and $5 \mathrm{~m}$ thick and are found along streams and rivers. The till consists of gravel and boulders in a silty matrix (Pacific Rim Planners, 1979; Marcher, 1971b; Selkregg, 1976). A well log from an 8.5-meter-deep well drilled near the FAA facilities indicates organic muck to about 2.5 -meter depth; gravel to about $2.7 \mathrm{~m}$; clay and gravel to about $7.0 \mathrm{~m}$; clay, gravel, and water to $8.5 \mathrm{~m}$; and bedrock below $8.5 \mathrm{~m}$ (Appendix 6; Marcher, 1971a). 


\section{Hydrology}

\section{Surface Water}

The rain that falls on Annette Island, particularly during the fall season, runs into the sea through numerous small streams. Streamflow ranges from 0.01 to $2.8 \mathrm{~m}^{3} / \mathrm{s}$ (Pacific Rim Planners, 1977). Elevations on Metlakatla Peninsula do not exceed $60 \mathrm{~m}$. Runoff generally is towards surface-water drainages that eventually empty into Nichols Passage to the west and Tamgas Harbor to the east. The basin on the west side of the peninsula drains an area of about $25 \mathrm{~km}^{2}$, and the basin on the east drains an area of about $22 \mathrm{~km}^{2}$ (Pacific Rim Planners, 1979).

Lakes on the Metlakatla Peninsula are shallow and are fed by runoff from the surrounding muskeg. Chester Lake and Yellow Lake are the principal freshwater bodies near the FAA facilities (fig. 9). Chester Lake is about $6 \mathrm{~km}$ northeast of the facilities and has a surface area of about $0.4 \mathrm{~km}^{2}$. The lake is the main source of drinking water for the Metlakatla community. Yellow Lake is about $4 \mathrm{~km}$ north of the facilities and has a surface area less than $0.2 \mathrm{~km}^{2}$. Yellow Lake currently supplies water to the Annette Island airport and the FAA facilities. Expanses of wetland and bog surround the facilities in all directions.

\section{Ground Water}

Ground water on Annette Island occurs within bedrock fractures and beach deposits (Appendix 6; Marcher, 1971 a and b). In general, the metamorphic and igneous bedrock underlying most of the island will yield less than $0.6 \mathrm{~L} / \mathrm{s}$ of water (Selkregg, 1976). Wells drilled in the highly fractured ultrabasic rocks south of Yellow Lake may yield larger amounts. Marcher (1971a) reported that a 110-meter-deep well was pumped from $99 \mathrm{~m}$ below land surface at a rate of $2.3 \mathrm{~L} / \mathrm{s}$ for 72 hours. A 24.4-meter drawdown was recorded. After pumping, the static water level was maintained at $7.0 \mathrm{~m}$ below ground surface. The aquifer has a freshwater/seawater contact. Extensive pumping of wells may lower the water table allowing saltwater intrusion.

Beach deposits on Annette Island are a potential aquifer (Appendix 6; Marcher, 1971b). These deposits are between 1.5 and $3.0 \mathrm{~m}$ thick and receive nearly continuous recharge because of well-distributed yearly precipitation (table 13). A well log from well 3 (fig. 9) indicated that water was reached at depths between 0.6 and $2.7 \mathrm{~m}$, and between 7.3 and $8.5 \mathrm{~m}$ below land surface (Appendix 6).

\section{Drinking Water}

Chester Lake and Yellow Lake are the principal drinking-water sources on the Metlakatla Peninsula (fig. 9). Chester Lake has been used as a source of water since the founding of the Metlakatla community. The water is chlorinated and piped to local residents (Selkregg, 1976; Environmental Services, Ltd., 1983). Analyses of water from Chester Lake in 1961 indicated that most major ions and water properties were within current USEPA regulations (table 14; Appendix 6). Yellow Lake provides drinking water to residences and businesses at the southern end of the peninsula including the FAA facilities, the National Weather Service, and a local hatchery. The water is abundant and is of acceptable quality (table 14; Appendix 6). 
Analyses of ground water indicated that some major ions exceeded current USEPA drinkingwater regulations (table 14; Appendix 6; Marcher, 1971a). About 30 percent of the samples contained iron concentrations above the current regulation of $0.3 \mathrm{mg} / \mathrm{L}$. Concentrations of sodium, sulfate, chloride, and total dissolved solids increased with depth, and suggest a mixture of seawater with freshwater (Marcher, 1971a).

Table 14. Water-quality data for Annette Island, Alaska

[Concentrations in $\mathrm{mg} / \mathrm{L}$, milligrams per liter]

\begin{tabular}{lcccc}
\hline \multicolumn{1}{c}{ Constituent (or property) } & $\begin{array}{c}\text { USEPA } \\
\text { drinking-water } \\
\text { regulation }\end{array}$ & $\begin{array}{c}\text { FAA facility, } \\
\text { well water } \\
1964-65\end{array}$ & $\begin{array}{c}\text { Chester Lake } \\
1961,1968\end{array}$ & $\begin{array}{c}\text { Yellow Lake } \\
1961-68\end{array}$ \\
\hline Chloride (Cl) & 250 & $5.7-642$ & $1.4-2.5$ & $.2-64$ \\
Iron (Fe) & .3 & $.04-.7$ & $.02-.1$ & $.03-.1$ \\
Sulfate $\left(\mathrm{SO}_{4}\right)$ & 250 & $3.8-327$ & $.0-1.0$ & $.0-5.0$ \\
Fluoride $(\mathrm{F})$ & 2 & $.1-1.2$ & 0 & $.0-.7$ \\
Total dissolved solids & 500 & $280-1,970$ & $5.0-8.0$ & $27-30$ \\
$\mathrm{pH}$ (units) & $6.5-8.5$ & $8.2-9.0$ & $5.9-6.1$ & $6.6-7.1$ \\
\hline
\end{tabular}

\section{SISTERS ISLAND}

\section{Location and Facility History}

Sisters Island is a $0.15 \mathrm{~km}^{2}$ volcanic island in Icy Strait. It is about $75 \mathrm{~km}$ west of Juneau near lat $58^{\circ} 10^{\prime} \mathrm{N}$., long $135^{\circ} 15^{\prime} \mathrm{W}$. (figs. 1 and 10). In 1945, the FAA established air-navigation facilities on Sisters Island. The FAA facilities on Sisters Island include an H-Marker facility, a VeryHigh Frequency Omnidirectional Range Tactical Air Navigation (VORTAC) facility, emergency quarters, a underground fuel-storage tank, a helicopter landing area, and living quarters. A more detailed list of FAA facilities on Sisters Island and a list of potential sources of contamination can be found in an environmental compliance investigation report by Ecology and Environment Inc. (1992g).

\section{Climate}

Sisters Island has a mean annual temperature of $6.7^{\circ} \mathrm{C}$. Temperatures range from a July mean maximum of $15.5^{\circ} \mathrm{C}$ to a January mean minimum of $-0.3{ }^{\circ} \mathrm{C}$ (Leslie, 1989). Mean annual precipitation is about $830 \mathrm{~mm}$ and mean annual snowfall is about $430 \mathrm{~mm}$. Mean monthly and annual temperature, precipitation, and snowfall are summarized in table 15 (Leslie, 1989). 


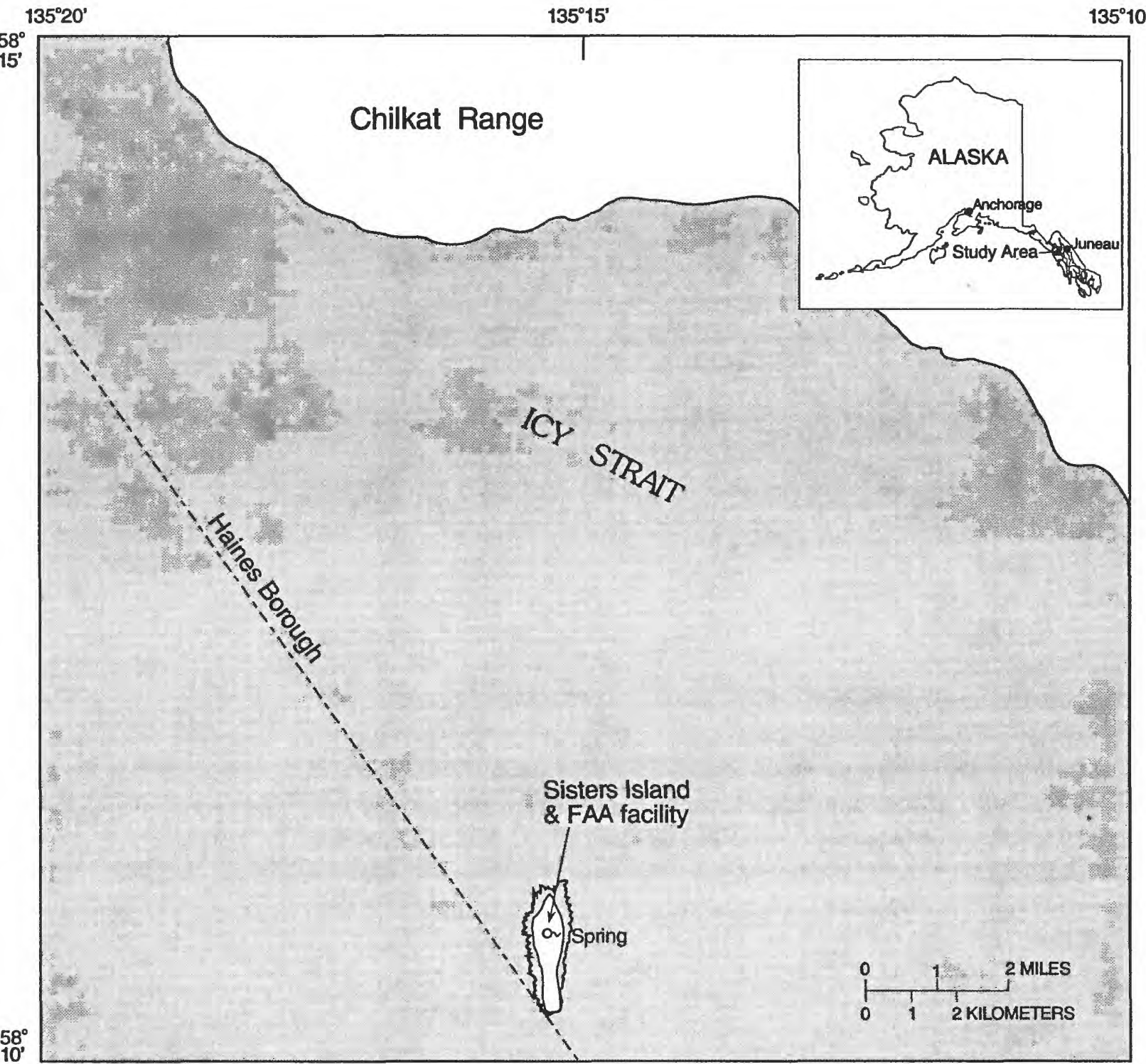

Base from U.S. Geological Survey, Juneau (A-4), Alaska, 1:63,360, 1949

Figure 10. Location of Sisters Island, Alaska and the Federal Aviation Administration facility. 
Table 15. Mean monthly and annual temperature, precipitation, and snowfall, 1982 to 1984 , Sisters Island, Alaska.

[Modified from Leslie (1989); ${ }^{\circ}$ C, degree Celsius]

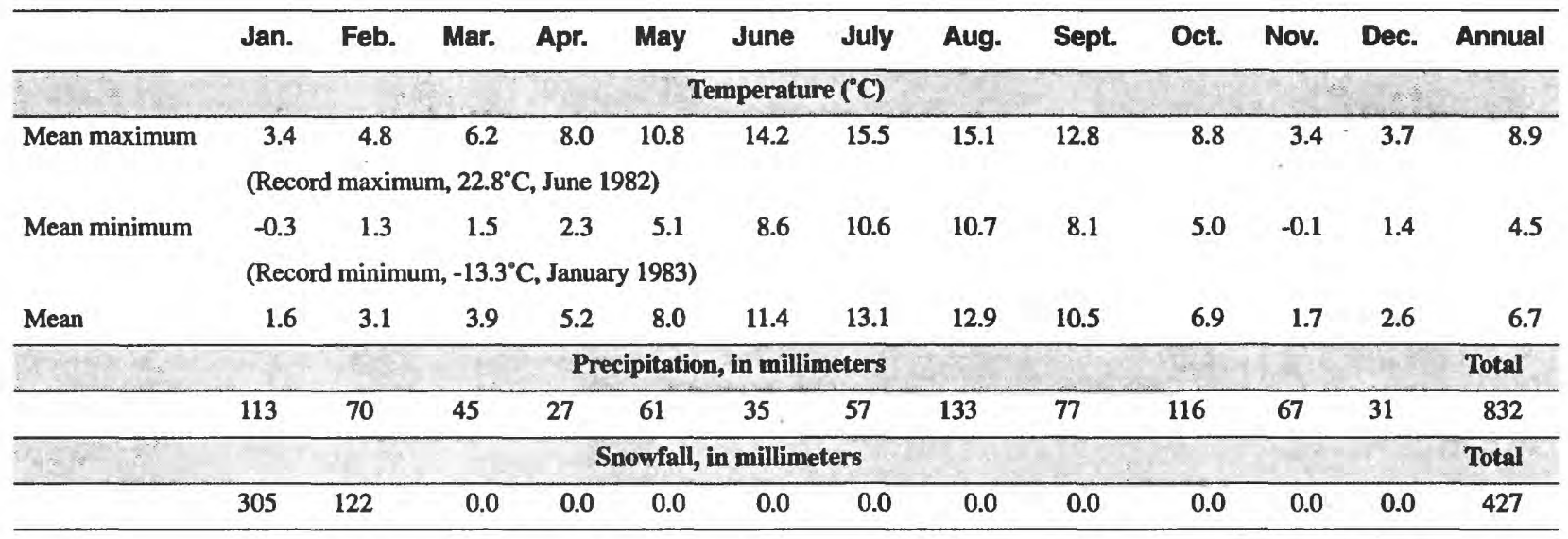

\section{Geology}

The geology of Sister Island has been described by Lathram and others (1959), Couch and Gemperle (1974), Brew and Ford (1985), and Berg and Gehrels (1992). The bedrock underlying the island is a volcanic flow breccia of dark greenish-gray basalt (Lathram and others, 1959; Brew and Ford, 1985). Bedrock lies close to the land surface, and about $30 \mathrm{~m}^{2}$ of bedrock are exposed (Brew and Ford, 1985). Surficial materials are predominately glacial sand, gravel, and silt. The soils that develop on these well-drained deposits are typically less than $50 \mathrm{~cm}$ thick over bedrock. The soils are characterized by an organic-rich layer 5 to $12 \mathrm{~cm}$ thick, and dark, acidic sublayers (Rieger and others, 1979).

\section{Hydrology}

\section{Surface water}

No large streams, rivers, or lakes are present on Sisters Island; however, a spring, small seeps, marshes, coastal tidelands, and freshwater wetlands exist in several places (Ecology and Environment, Inc., 1992g). Regional runoff for the Sisters Island area is estimated to be about $0.1\left(\mathrm{~m}^{3} / \mathrm{s}\right) / \mathrm{km}^{2}$ (Selkregg, 1976).

\section{Ground water}

In general, geologic factors such as porosity, permeability, topography, and mineralogic composition control the occurrence and availability of ground water. A spring on Sisters Island (fig. 10) originates from the underlying bedrock. Basalt-flow bedrock tends to exhibit minimal porosity and hydraulic conductivity in the middle to lower section of a given unit, and higher porosities and permeabilities in the interflow zone-the area between the top of one unit and the bottom of the next (Wood and Fernandez, 1988). Porosities for basalt flows average about 5 per- 
cent; hydraulic conductivities range from less than $10^{-11}$ to greater than $10^{3} \mathrm{~m} / \mathrm{d}$ (Wood and Fernandez, 1988). Specific values for the hydraulic properties of the bedrock underlying Sisters Island are unknown. Water from the Sisters Island spring is pumped to a holding tank and is used as nonpotable "gray" water for the emergency living quarters. The quantity and quality of water available from this spring are unknown, although a sample collected by Ecology and Environment Inc. $(1992 \mathrm{~g})$ indicated low concentrations of zinc and copper.

\section{Drinking Water}

Surface water and ground water are not used for drinking water on Sisters Island because no one resides on the island. When needed, drinking water is brought in from outside sources (Ecology and Environment Inc., 1992g). No surface- or ground-water data are available to determine their use as potential drinking-water sources. Selkregg (1976) describes ground-water availability in southeast Alaska as about 0 to $0.6 \mathrm{~L} / \mathrm{s}$.

\section{DUNCAN CANAL}

\section{Location and Facility History}

Duncan Canal is at Indian Point on Kupreanof Island about $16 \mathrm{~km}$ southwest of Petersburg at lat $56^{\circ} 45^{\prime} \mathrm{N}$., long $133^{\circ} 15^{\prime} \mathrm{W}$. (figs. 1 and 11). In 1945, the FAA began operations at Duncan Canal when an air-navigation station was established. The FAA vacated the property in 1976 and the operational responsibilities for fuel tanks and associated pipes and pumps were transferred to the U.S. Forest Service. Formerly owned and operated FAA facilities at Duncan Canal include navigation and communication equipment and support structures. A detailed list of FAA facilities at Duncan Canal and a list of potential sources of contamination can be found in an environmental compliance investigation report by Ecology and Environment Inc. (1992h).

\section{Climate}

No specific climate data are available for the FAA facility at Duncan Canal. The nearest site for which climate data are available are Petersburg, about $16 \mathrm{~km}$ northeast, and Kake, about $50 \mathrm{~km}$ northwest. There are significant differences in the amount of annual precipitation that falls on Kake and Petersburg; Kake receives about 1,440 $\mathrm{mm}$ and Petersburg receives about 2,690 $\mathrm{mm}$. The amount of precipitation that Duncan Canal receives probably falls within this range. Most rainfall occurs from October through January. The mean annual temperature for the Duncan Canal area likely ranges from 9.3 to $9.7^{\circ} \mathrm{C}$. Temperatures range from mean maximums in July and August between 17.2 and $17.6{ }^{\circ} \mathrm{C}$ to mean minimums in January between -3.3 and $-5.4{ }^{\circ} \mathrm{C}$ (Leslie, 1989). Mean monthly and annual temperature, precipitation, and snowfall for Kake and Petersburg are summarized in tables 16 and 17 (Leslie, 1989). 


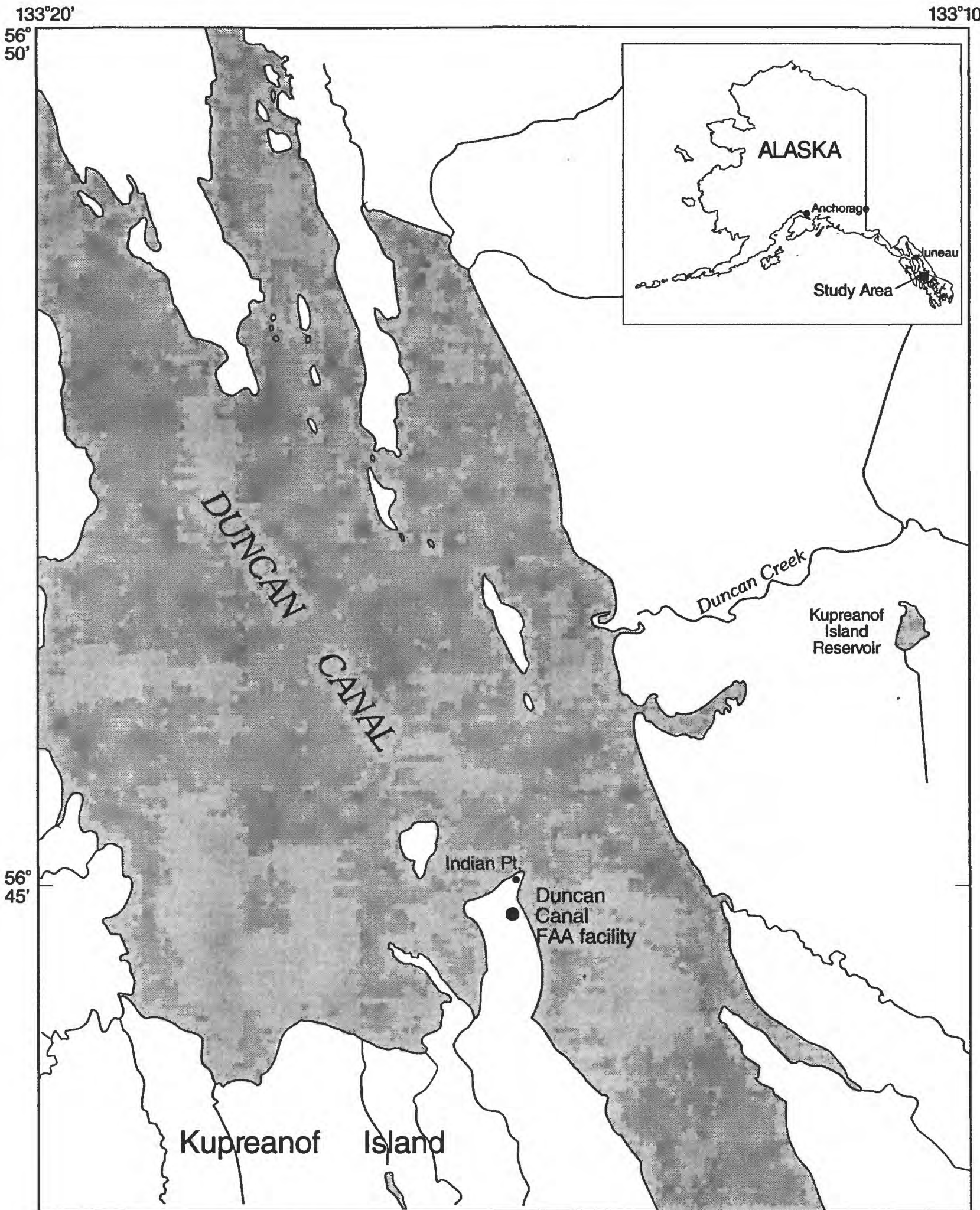

Base from U.S.Geological Survey, Petersburg (C-4, D-4), Alaska, 1:63,360, 1951

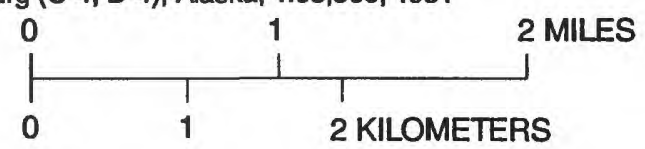

Figure 11. Location of Duncan Canal, Alaska and the Federal Aviation Administration facility. 
Table 16. Mean monthly and annual temperature, precipitation, and snowfall, Kake, Alaska, 1922-87. [Modified from Leslie (1989); ${ }^{\circ} \mathrm{C}$, degree Celsius]

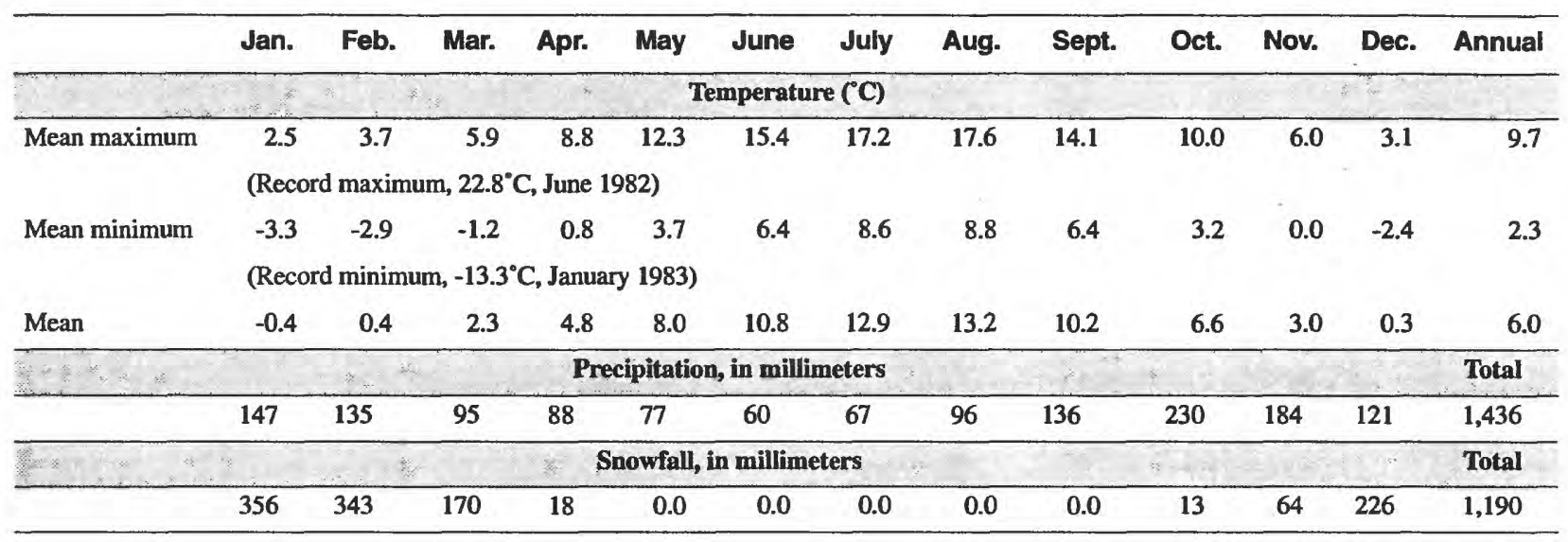

Table 17. Mean monthly and annual temperature, precipitation, and snowfall, Petersburg, Alaska, 1922-87.

[Modified from Leslie (1989); ${ }^{\circ} \mathrm{C}$, degree Celsius]

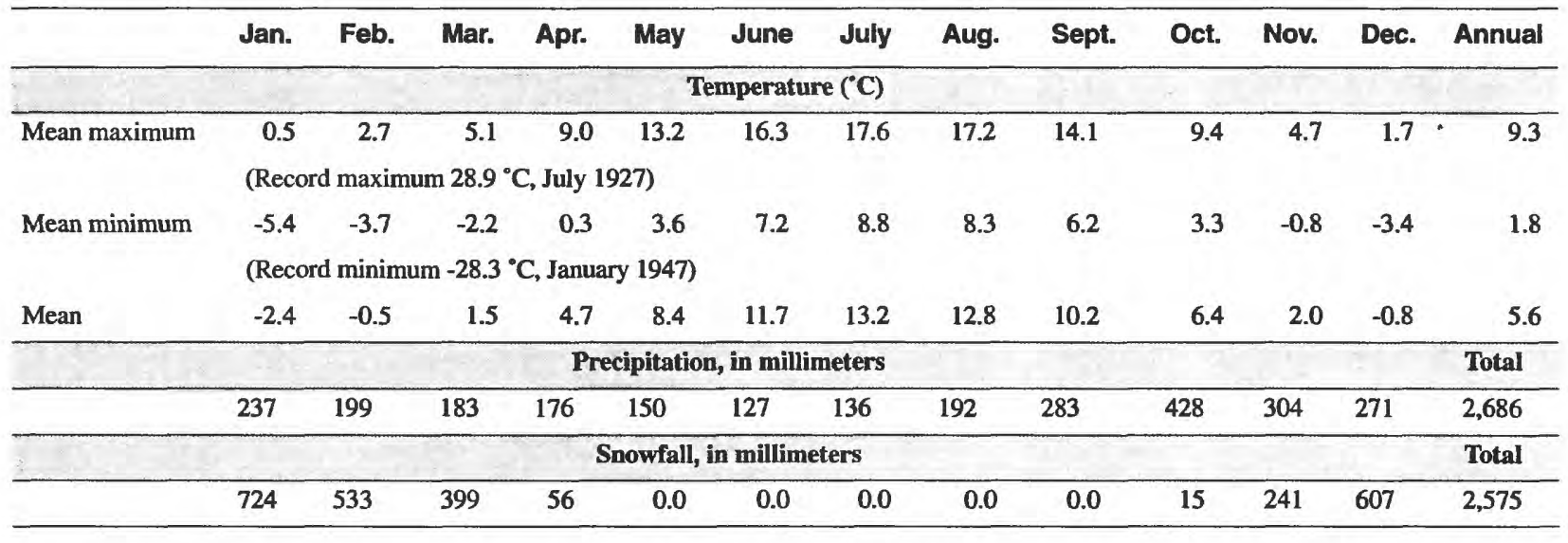

\section{Geology}

Sedimentary bedrock of Cretaceous to Devonian age underlies the Duncan Canal FAA facility (Berg and Gehrels, 1992). The bedrock consists of highly deformed, disrupted, and metamorphosed graywacke, siltstone, mudstone, and minor amounts of chert, limestone, and volcanic and intrusive rocks (Berg and Gehrels, 1992). Depth to bedrock is unknown. Sand and gravel are the principal surficial materials found near the FAA facility. The material is probably derived from the weathering and glacial erosion of rocks on Kupreanof Island. The thickness of surficial materials is unknown.

Soils on Kupreanof Island near Duncan Canal are of two major types (Rieger and others, 1979). Well-drained acidic soils are associated with nearby forested areas. Under a thick mat of partially to highly decomposed forest litter, these soils have a thin gray, organic-rich surface layer 
and black, acidic subsurface layers (Rieger and others, 1979). Thick layers of poorly drained, organic-rich soils are found in low-lying areas and on slopes that are subject to ground-water seepage (Rieger and others, 1979). Kupreanof Island is in an area that typically is free of permafrost (Ferrians, 1965).

\section{Hydrology}

\section{Surface Water}

Several small streams and ponds are present south-southwest of the Duncan Canal FAA facility. The ponds are less than $0.4 \mathrm{~km}^{2}$ in size and are at elevations between 55 and $80 \mathrm{~m}$ above sea level. The streams flow from upland areas toward the coast (fig. 11). Specific streamflow and drainage-area data are not available for these streams. Mean annual runoff near the Duncan Canal facility is estimated to be $0.09\left(\mathrm{~m}^{3} / \mathrm{s}\right) / \mathrm{km}^{2}$ (Selkregg, 1976). The Kupreanof Island Reservoir is about $5 \mathrm{~km}$ northwest of the facility across Duncan Canal (fig. 11). It lies about $90 \mathrm{~m}$ above sea level. Wetland areas lie within $0.2 \mathrm{~km}$ of the FAA facility (Ecology and Environment Inc., 1992h).

\section{Ground Water}

Site-specific ground-water data are not available for the Duncan Canal FAA facility. An abandoned well used by the FAA was drilled to a depth of $8 \mathrm{~m}$ indicating that ground water is probably present above this depth. Ground water probably is recharged along the slopes south and west of the FAA facility and likely follows local topography and flows toward the coast.

\section{Drinking Water}

The Duncan Canal FAA facility is currently uninhabited and there are no people living within a $6.5 \mathrm{~km}$ radius (Ecology and Environment Inc., 1992h). When needed, drinking water is transported to the island. Alternative sources of drinking water may include local streams and ponds; however, data are inadequate to characterize the quality or quantity of these sources. The use of the Kupreanof Island Reservoir would be uneconomical.

\section{SUMMARY}

Coastal areas of south-central and southeast Alaska-including Middleton Island, Cape Yakataga, Gustavus, Haines, Biorka Island, Big Level Island, Annette Island, Sisters Island, and Duncan Canal-have a maritime climate characterized by mild winters and cool summers. Most communities obtain their drinking water from surface-water sources, such as lakes, streams, and rivers, whereas other communities use water from shallow unconfined aquifers. Surface spills and disposal of hazardous materials may affect the quality of drinking water.

Parts of Alaska's Pacific coast receive more than 2,500 mm/yr of precipitation (Hartman and Johnson, 1984). Because of steep topographic gradients, most of this precipitation runs off rapidly into lakes and streams as surface water, and only a minor amount infiltrates to the ground-water system (Selkregg, 1976). Most of the small lakes, rivers, and creeks in southeast Alaska drain from the west side of the Coast Mountains and St. Elias Mountains, and from the islands of the Archipelago directly into the sea. Coastal and island sites in south-central and southeast Alaska are 
areas that typically are free of permafrost (Ferrians, 1980). Mean annual runoff rates range from about 0.02 to more than $0.14\left(\mathrm{~m}^{3} / \mathrm{s}\right) / \mathrm{km}^{2}$ (B.B. Bigelow, U.S. Geological Survey, written commun., 1995).

Ground-water data for the FAA facilities in south-central and southeast Alaska are sparse. Water-bearing surficial materials include alluvial and glacial deposits that are found at depths that typically range from 3 to $30 \mathrm{~m}$ below land surface (Selkregg, 1976). Ground water may also occur in fractured bedrock. Freshwater occurs beneath islands and coastal areas as a "freshwater lens" that floats on saltwater within the aquifer (Hunt and others, 1988). This is sometimes referred to as basal water and can occur under confined or unconfined conditions (Hunt and others, 1988). Basal water often extends to depths below sea level of about 40 times the water-table elevation or potentiometric surface. Near the base of the lens, freshwater grades into saltwater in a transition zone that may range from a few meters to a few hundred meters (Hunt and others, 1988). The possibility of saltwater intrusion into coastal and island aquifers increases with depth and pumping rate.

In general, surface water in southeastern Alaska is of acceptable drinking-water quality (Selkregg, 1976). Dissolved-solids concentrations typically are below the current USEPA drinking-water regulation of $500 \mathrm{mg} / \mathrm{L}$. Streams draining low-lying areas may contain excessive amounts of iron and organic material. Large glacier-fed rivers may contain high silt concentrations especially in the summer. In general, ground water also is of acceptable quality and typically is a calcium bicarbonate type. Ground water in coastal areas may be a sodium chloride or sodium bicarbonate type due to salt-water influences.

\section{REFERENCES CITED}

Alaska Department of Environmental Conservation (ADEC), 1995, Alaska water-quality standards 18 AAC 70: Alaska Department of Environmental Conservation, Water-Quality Management Section, Juneau, AK, 47 p.

Berg, H.C., and Gehrels, G.E., 1992, Geologic map of Southeastern Alaska: U.S. Geological Survey Miscellaneous Investigations Series Map I-1867, 24 p., 1 sheet.

Brower, W.A., Searby, H.W., and Wise J.L., 1977, Climatic atlas-The outer continental shelf waters and coastal regions of Alaska: University of Alaska Anchorage, Arctic Environmental Information Center, v. 1, 439 p.

Bugliosi, E.F., 1988, Hydrologic reconnaissance of the Chilkat River Basin, Southeast Alaska, with special reference to the Alaska Chilkat Bald Eagle Preserve: U.S. Geological Suryey Water-Resources Investigations Report 884023, 38 p.

Couch, R.W., and Gemperle, M., 1974, Tectonics of the Continental Margin between Icy Strait and Icy Bay, Alaska.: Eos, v. 55 , no. 2 , p. 76.

Doerr, J.G., and Sandburg, N.H., 1986, Effects of precommercial thinning on understory vegetation and deer habitat utilization on Big Level Island in Southeast Alaska: Forestry Science, v. 32, no. 4, p. 1092-1095.

Ecology and Environment, Inc., 1992a, Environmental compliance investigation report, Middleton Island FAA station, Middleton Island, Alaska: Anchorage, Ecology and Environment Inc. [Copy available from the Environmental Compliance Section, AAL-465, Federal Aviation Administration, Alaskan Region], variously paged.

1992b, Environmental compliance investigation report, Cape Yakataga FAA station, Cape Yakataga Alaska: Anchorage, Ecology and Environment Inc. [Copy available from the Environmental Compliance Section, AAL465, Federal Aviation Administration, Alaskan Region], variously paged. 
1992c, Environmental compliance investigation report, Gustavus FAA station, Gustavus Alaska: Anchorage, Ecology and Environment Inc. [Copy available from the Environmental Compliance Section, AAL-465, Federal Aviation Administration, Alaskan Region], variously paged.

1992d, Environmental compliance investigation report, Biorka Island air navigation station, Biorka Island Alaska: Anchorage, Ecology and Environment Inc. [Copy available from the Environmental Compliance Section, AAL-465, Federal Aviation Administration, Alaskan Region], variously paged.

1992e, Environmental compliance investigation report, Big Level Island FAA station, Big Level Island Alaska: Anchorage, Ecology and Environment Inc. [Copy available from the Environmental Compliance Section, AAL465, Federal Aviation Administration, Alaskan Region], variously paged.

1992f, Environmental compliance investigation report, Annette Island FAA station, Annette Island Alaska: Anchorage, Ecology and Environment Inc. [Copy available from the Environmental Compliance Section, AAL465, Federal Aviation Administration, Alaskan Region], variously paged.

1992g, Environmental compliance investigation report, Sisters Island FAA station, Sisters Island Alaska: Anchorage, Ecology and Environment Inc. [Copy available from the Environmental Compliance Section, AAL465, Federal Aviation Administration, Alaskan Region], variously paged.

1992h Environmental compliance investigation report, Duncan Canal FAA station, Kupreanof Island Alaska: Anchorage, Ecology and Environment Inc. [Copy available from the Environmental Compliance Section, AAL465, Federal Aviation Administration, Alaskan Region], variously paged.

1994, Environmental compliance investigation report, Haines FAA station, Haines Alaska: Anchorage, Ecology and Environment Inc. [Copy available from the Environmental Compliance Section, AAL-465, Federal Aviation Administration, Alaskan Region], variously paged.

Environmental Services, Ltd., 1979, City of Haines coastal management plan: Haines, Alaska, City of Haines, 136 p.

1983, Haines-an Alaska community profile: Juneau, Alaska Department of Commerce and Economic Development, 7 p.

Ferrians, O.J., Jr., 1980, Permafrost map of Alaska: U.S. Geological Survey Miscellaneous Geologic Investigations Map I-445, 1 sheet, scale 1:250,000.

Hartman, C.W., and Johnson, P.R., 1984, Environmental atlas of Alaska: University of Alaska Fairbanks, Institute of Water Resources/Engineering Experiment Station, 95 p.

Hudson, T., Plafker, G., and Rubin, M., 1976, Uplift rates of marine terrace sequences in the Gulf of Alaska: U.S. Geological Survey Circular 733, p. 11-13.

Hunt, C.D., Ewart, C.J., and Voss, C.I., 1988, Hawaiian Islands in Back, W., and others, eds., Hydrogeology: Boulder, Colorado, Geological Society of America, The geology of North America, v. O-2. p. 255-263.

Jones, S.H., and Fahl, C.B., 1994, Magnitude and frequency of floods in Alaska and conterminous basins of Canada: U.S. Geological Survey Water-Resources Investigations Report 93-4179, 122 p.

Lathram, E.H., Loney, R.A., Condon, W.H., and others, 1959, Progress map of the geology of the Juneau Quadrangle, Alaska: U.S. Geological Survey Miscellaneous Investigations Series Map I-303,

Leslie, L.D., 1989, Alaska climate summaries (2d ed.): University of Alaska Anchorage, Arctic Environmental Information and Data Center, Alaska Climate Center Technical Note 5, variously paged.

Marcher, M.V., 1971a, Reconnaissance of ground water supplies from bedrock in the Metlakatla Peninsula, Annette Island, Alaska: U.S. Geological Survey Professional Paper 750-D, p. D198-D201.

$1971 \mathrm{~b}$, Raised-beach deposits and their ground water potential in the southern part of the Metlakatla Peninsula, Annette Island, Alaska: U.S. Geological Survey Professional Paper 750-D, p. D202-D205.

McConaghy, J.A., 1970, Reconnaissance of water resources in the Haines-Port Chilkoot area, Alaska: U.S. Geological Survey Circular 626, $16 \mathrm{p}$.

Miller, D.J., 1971, Geologic map of the Yakataga district, Gulf of Alaska Tertiary province, Alaska: U.S. Geological Survey Miscellaneous Investigations Map I-610, scale 1:250,000. 
Pacific Rim Planners, 1977, Metlakatla Indian community Annette Islands reserve land use and housing plan: Seattle, Washington, Pacific Rim Planners, 139 p.

1979, Annette Islands Reserve coastal management program: Metlakatla, Alaska, Metlakatla Indian Community, $161 \mathrm{p}$.

Prescott, W.H., and Lisowski, M., 1977, Deformation at Middleton Island, Alaska, during the decade after the Alaska earthquake of 1964: Seismology Society of America Bulletin, v. 67, no. 3, p. 579-586.

Rieger, Samuel, Schoephorster, D.B., and Furbush, C.E., 1979, Exploratory soil survey of Alaska: U.S. Soil Conservation Service report, $213 \mathrm{p}$.

Selkregg, L., 1976, Alaska regional profiles--Southeast Region: Anchorage, University of Alaska, Arctic Environmental Information and Data Center, $234 \mathrm{p}$.

Stephens, C.D., Fogleman, K.A., Lahr, J.C., and Page, R.A., 1986, Seismicity in southern Alaska, in Geologic studies in Alaska: U.S. Geological Survey Circular 978, p. 81-85.

U.S. Army Corps of Engineers, 1989, Southeast Alaska harbors of refuge: U.S. Army Corps of Engineers, Draft Feasibility Report and Environmental Impact Statement, 162 p. 1993, Flood hazard data, Alaska communities, Alaska: U.S. Army Corps of Engineers, 335 p.

U.S. Bureau of Census, 1991, Percent distribution Alaska population by sex, race and Hispanic origin--1990 census: Anchorage, Alaska Department of Labor, Research and Analysis compilation report, 3 p.

U.S. Fish and Wildlife Service, 1989, National wetlands inventory: U.S. Fish and Wildlife Service, Petersburg quadrangle map, scale 1:63,360, 1 sheet.

U.S. Geological Survey, 1962, Surface-water supply of the United States, 1961-65, Alaska: U.S. Geological Survey Water-Supply Paper 1936.

Viereck, L.A, and Little, E.L., 1972, Alaska trees and shrubs: U.S. Department of Agriculture, Agriculture Handbook 410, 265 p.

Waller, R.M., and Tolen, D.A., 1962, Data on ground-water exploration and development in southeastern Alaska: U.S. Geological Survey Hydrological Data Report 19, 15 p.

Wood, W.W., and Fernandez, L.A., 1988, Volcanic rocks in Back, W., and others, eds., Hydrogeology: Boulder, Colorado, Geological Society of America, The geology of North America, v. O-2. p. 353-367.

Winkler, G.R., and Plafker, G., 1993, Geologic map of the Cordova and Middleton Island quadrangles, Southern Alaska: U.S. Geological Survey Miscellaneous Investigations Series Map I-1984, scale 1:250,000.

Yehle, L.A., 1977, Reconnaissance engineering geology and geologic hazards of the Metlakatla area, Annette Island: U.S. Geological Survey Circular 751-B, p. B72. 


\section{APPENDIX 1}

Data for Middleton Island, Alaska 


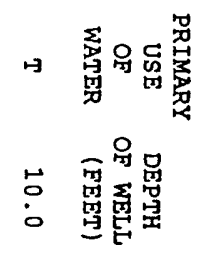

）可暑蛋

嘼照男

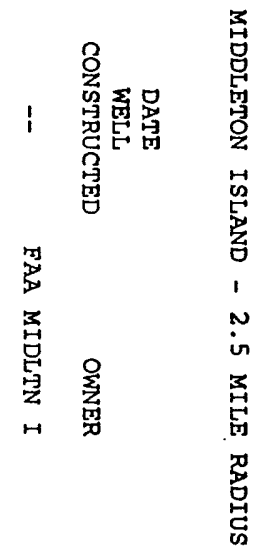

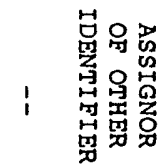

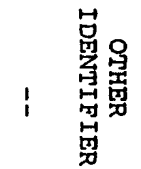

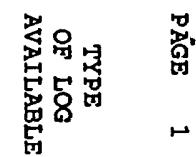




\section{APPENDIX 2}

Data for Cape Yakataga, Alaska 

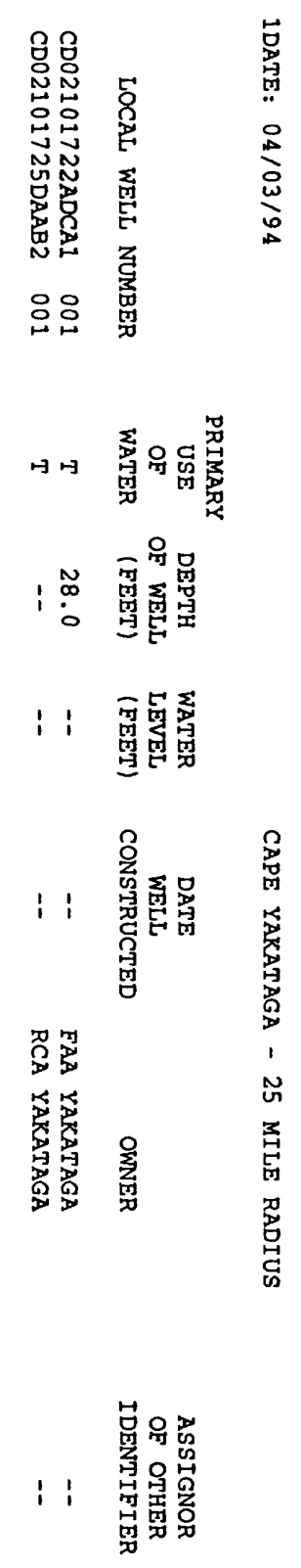

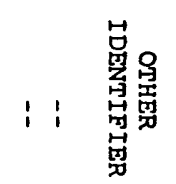

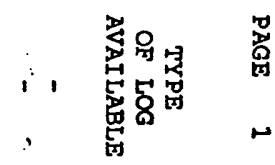




\section{APPENDIX 3}

Data for Gustavus, Alaska 


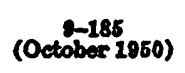

\section{UNITED STATES \\ DEPARTMENT OF THE INTERIOR \\ GEOLOGICAL SURVEY \\ WATER RESOURCES DIVISION}

WELL SCHEDULE

Date

$2 / 29$

19.65 Fild No.

Reoord by

Offico No.

Source of data.

1. Location: Btate AlasKa County Glasier Bay NM Map - JuneaU $=\alpha 5815-w 13540 / 15 \times 20$

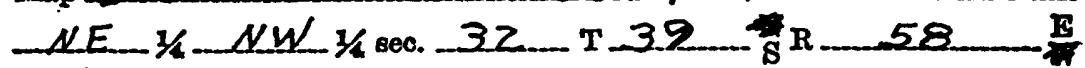

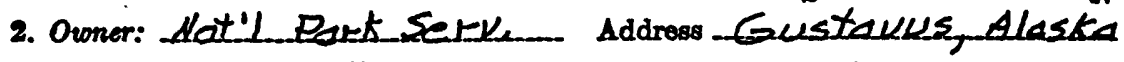
Tenant Driller HiO, Meyers Address Seaftleg-Hena

3. Topography

4. Elevation 55

ft. above Address

5. Type:

6. Type: Bug, drillod, drivored, jotted..8/19k5

7. Casing: Diam. G in., to - G in., Type C.Is

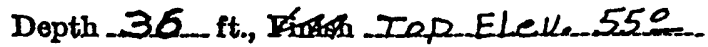

8. Chief Aquifer .... Fine sand . From ... Others Seme gravel trace

o. Water level Eleke $36 \mathrm{ft}$. rept. which is $\ldots 19$

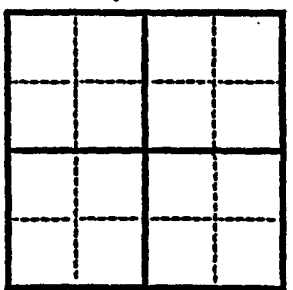

10. Pump: Type Capacity ft. to 36 ft.

Power: Kind

11. Yield: Flow 70 G.M., Horsepower above 19._. above ft. abors surface G. M.

.

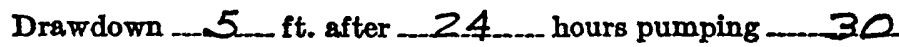
G. M.

12. Use: Dom., Stock, PS., RR., Ind., Irr., Obs. ....Damestíc Adequacy, permanence Yes

13. Quality Temp

Taste, odor, color fiftlenot asue Sample $\frac{160}{10} 18580$

Unfit for

14. Remarks: (Log, Analyses, oto.) Leq Avaílable NPS, Tuneaur Sand Samples twaile, Aquifer Siéve Analysis Available. 


\section{WATER ANALYSIS}

Location

Source

Cased to (ft)

Treatment

WBF

Temp $\left({ }^{\circ} \mathrm{F}\right)$

Collected

Remarks
Date drilled Owner
County

$$
\text { Depth (ft) If Diam (in.) }
$$

\begin{tabular}{|c|c|c|c|c|c|}
\hline & and & epm & & Pitiv & epm \\
\hline Silica $\left(\mathrm{SiO}_{2}\right)$ & 6 & & Bicarbonate $\left(\mathrm{HCO}_{3}\right)$ & ans & 2.4 \\
\hline Aluminum (Al) & wim & & Carbonate $\left(\mathrm{CO}_{3}\right)$ & 0 & .09 \\
\hline \multicolumn{6}{|l|}{ Iron (Fe) } \\
\hline & & & Sulfate $\left(\mathrm{SO}_{4}\right)$ & 8 & 7 \\
\hline & & & Chloride (Cl) & 1.6 & .04 \\
\hline & & & Fluoride (F) & .0 &.$\infty$ \\
\hline Calcium (Ca) & 64 & 8,80 & & & \\
\hline Magnesium (Mg) & 4. & 6 & Nitrate $\left(\mathrm{NO}_{3}\right)$ & .0 & .00 \\
\hline Sodium $(\mathrm{Na})$ & 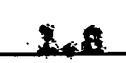 & +0 & & & \\
\hline Potassium (K) & s.8 & on & & & \\
\hline Total & & 40 & Total & & 486 \\
\hline
\end{tabular}

\begin{tabular}{|c|c|c|c|}
\hline & $\square$ & & \\
\hline & $\pi / 5$ & $\begin{array}{l}\text { Specific conductance } \\
\left(\mathrm{micromhos} \text { at } 25^{\circ} \mathrm{C}\right)\end{array}$ & 50 \\
\hline $\begin{array}{l}\text { Dissolved solids: } \\
\text { Calculated }\end{array}$ & 4 & $x_{5}$ & 8.6 \\
\hline Residue on evaporation at $180^{\circ} \mathrm{C}$ & & Color & 0 \\
\hline$\frac{\text { Hardness as } \mathrm{CaCO}_{3}}{\text { Noncarbonate }}$ & $\frac{8 \infty 0}{n}$ & Color & \\
\hline & & & \\
\hline & & & \\
\hline
\end{tabular}




\section{WATER ANALYSIS}

Location _

Source

Cased to (ft)

Date drilled Dawner

Treatment

WBF

Temp ( $\left.{ }^{\circ} F\right)$ Appear, when coll.

Collected

Apse in $\rightarrow$

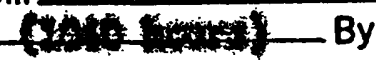

Remarks

County Depth (ft) -14 Diam (in.)

\begin{tabular}{|c|c|c|c|c|c|}
\hline & $n=m$ & epm & & mamis & epm \\
\hline Silica $\left(\mathrm{SiO}_{2}\right)$ & $1+$. & & Bicarbonate $\left(\mathrm{HCO}_{3}\right)$ & 4 & , \\
\hline Aluminum (Al) & $\Leftrightarrow$ & & Carbonate $\left(\mathrm{CO}_{3}\right)$ & 4 & .0 \\
\hline \multirow[t]{4}{*}{$\operatorname{Iron}(\mathrm{Fe})$} & 4 & & & & \\
\hline & & & Sulfate $\left(\mathrm{SO}_{4}\right)$ & $m$ & .4 \\
\hline & & & Chloride (Cl) & 14 & 45 \\
\hline & & & Fluoride (F) & .0 &.$\infty$ \\
\hline Calcium (Ca) & 4 & $\mathbf{x} z$ & & . & \\
\hline Magnesium (Mg) & Ite & $-\infty$ & Nitrate $\left(\mathrm{NO}_{3}\right)$ & 1 & $\infty$ \\
\hline \multicolumn{6}{|l|}{ Sodium (Na) } \\
\hline Potassium (K) & $1 *$ & .11 & & & \\
\hline Total & & a. & Total & . & 4.96 \\
\hline
\end{tabular}

\begin{tabular}{|c|c|c|c|}
\hline & $m$ & & \\
\hline & $\pi$ & $\begin{array}{l}\text { Specific conductance } \\
\left(\text { micromhos at } 25^{\circ} \mathrm{C}\right)\end{array}$ & 66 \\
\hline $\begin{array}{l}\text { Dissolved solids: } \\
\text { Calculated }\end{array}$ & $a^{*}$ & rist & 7.8 \\
\hline Residue on evaporation at $180^{\circ} \mathrm{C}$ & & Gatom & E \\
\hline$\frac{\text { Hardness as } \mathrm{CaCO}_{3}}{\text { Noncarbonate }}$ & $\frac{2 y}{27}$ & Color & $\mathbf{u}$ \\
\hline & & & \\
\hline & & & \\
\hline
\end{tabular}




\section{WATER ANALYSIS}

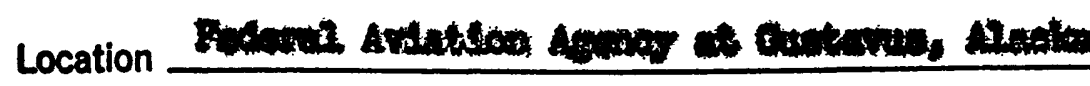

Source

Cased to (ft) Date drilled

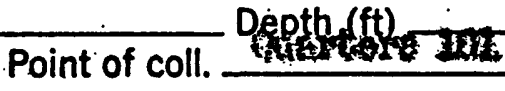
County

Treatment

WBF Owner

Temp. ( $\left.{ }^{\circ} \mathrm{F}\right)$ Corlected Aphear.

Remarks

\begin{tabular}{|c|c|c|c|c|c|}
\hline & ppm & epm & & $\mathrm{ppm}$ & epm \\
\hline Silica $\left(\mathrm{SiO}_{2}\right)$ & 9.2 & & Bicarbonate $\left(\mathrm{HCO}_{3}\right)$ & 20 & 3.76 \\
\hline Aluminum (Al) & & & Carbonate $\left(\mathrm{CO}_{3}\right)$ & 0 & 0.00 \\
\hline Iron $(F e)$ (dis) & 0.10 & & & & \\
\hline \multirow[t]{3}{*}{ 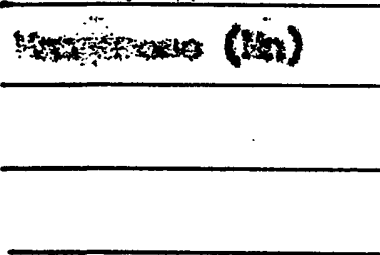 } & 0.00 & & Sulfate $\left(\mathrm{SO}_{4}\right)$ & 27 & 0.57 \\
\hline & & & Chloride (C1) & 5.9 & 0.25 \\
\hline & & & Fluoride (F) & 0.2 & 0.02 \\
\hline Calcium (Ca) & 3.6 & 0.318 & & . & \\
\hline Magnesium (Mg) & 0.5 & 0.04 & Nitrate $\left(\mathrm{NO}_{3}\right)$ & 0.2 & 0.00 \\
\hline Sodium $(\mathrm{Na})$ & 100 & 4.35 & & & \\
\hline Potassium (K) & 0.1 & 0.00 & & & \\
\hline \multicolumn{2}{|l|}{ Total } & 4.97 & \multicolumn{2}{|l|}{ Total } & 4.49 \\
\hline
\end{tabular}

\begin{tabular}{|c|c|c|c|}
\hline - & $\mathrm{ppm}$ & & \\
\hline & & $\begin{array}{l}\text { Specific conductance } \\
\left(\text { micromhos at } 25^{\circ} \mathrm{C}\right)\end{array}$ & 416 \\
\hline $\begin{array}{l}\text { Dissolved solids: } \\
\text { Calculated }\end{array}$ & $2 \% 8$ & (2) & 7.2 \\
\hline Residue on evaporation at $180^{\circ} \mathrm{C}$ & & & 10 \\
\hline$\frac{\text { Hardness as } \mathrm{CaCO}_{3}}{\text { Noncarbonate }}$ & $\frac{12}{0}$ & Color & \\
\hline Mitaling $\approx 00003$ & 158 & & \\
\hline
\end{tabular}

Use

$$
\text { By }
$$

Yield 
WATER-QUALITY DATA, WATER YEAR OCTOBER 1967 TO SEPTEMBER 1968

\begin{tabular}{|c|c|c|c|c|c|c|c|c|c|c|c|}
\hline DATE & $\begin{array}{c}\text { SODIUM } \\
\text { AD- } \\
\text { SORP- } \\
\text { TION } \\
\text { RATIO } \\
(00931)\end{array}$ & $\begin{array}{l}\text { SODIUN } \\
\text { PERCENT } \\
\text { (00932) }\end{array}$ & $\begin{array}{l}\text { POTAS- } \\
\text { SIUM, } \\
\text { DIS- } \\
\text { SOLVED } \\
(\text { MG /L } \\
\text { AS K) } \\
(00935)\end{array}$ & $\begin{array}{l}\text { CHLO- } \\
\text { RIDE, } \\
\text { DIS- } \\
\text { SOLVED } \\
\text { (MG/L } \\
\text { AS CL) } \\
(00940)\end{array}$ & $\begin{array}{l}\text { SULFATE } \\
\text { DIS- } \\
\text { SOLVED } \\
\text { (MG/L } \\
\text { AS SO4) } \\
(00945)\end{array}$ & $\begin{array}{l}\text { FLUO- } \\
\text { RIDE, } \\
\text { DIS- } \\
\text { SOLVED } \\
(\text { MG/L } \\
\text { AS F) } \\
(00950)\end{array}$ & $\begin{array}{l}\text { SILICA, } \\
\text { DIS- } \\
\text { SOLVED } \\
\text { (MG/L } \\
\text { AS } \\
\text { SIO2) } \\
(00955)\end{array}$ & $\begin{array}{l}\text { SOLIDS, } \\
\text { SUM OF } \\
\text { CONSTI- } \\
\text { TUENTS, } \\
\text { DIS- } \\
\text { SOLVED } \\
\text { (MG/L) } \\
\text { (70301) }\end{array}$ & $\begin{array}{c}\text { SOLIDS, } \\
\text { DIS- } \\
\text { SOLVED } \\
\text { (TONS } \\
\text { PER } \\
\text { AC-ET) } \\
(70303 \text { ) }\end{array}$ & $\begin{array}{c}\text { NITRO- } \\
\text { GEN, } \\
\text { NITRATE } \\
\text { DIS- } \\
\text { SOLVED } \\
\text { (MG/L } \\
\text { AS NO3) } \\
\text { (71851) }\end{array}$ & $\begin{array}{l}\text { IRON } \\
\text { (UG/L } \\
\text { AS FE) } \\
(71885)\end{array}$ \\
\hline & 0.7 & 84 & 0.0 & 1.4 & 0.0 & 0.0 & 0.90 & 5 & 0.01 & 0.10 & \\
\hline
\end{tabular}


WATER-QUALITY DATA, WATER YEAR OCTOBER 1960 TO SEPTEMBER 1961

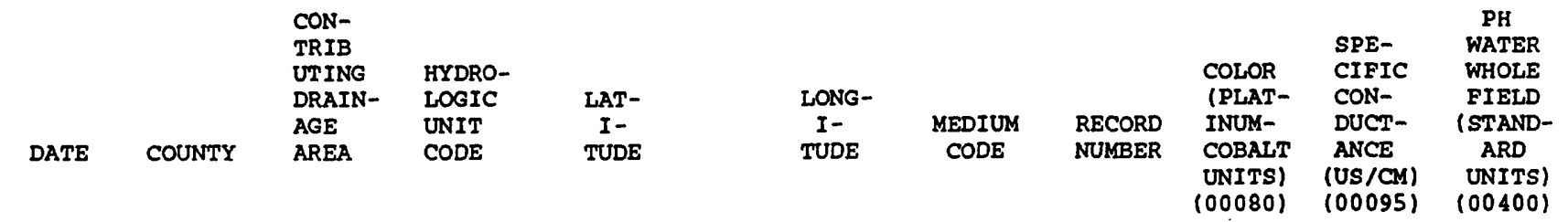

MAR

$15 \ldots . \quad 190$

$19010102550733 \mathrm{~N} \quad 1313130 \mathrm{~W}$

$9 \quad 96100004$

5

11

6.1

\begin{tabular}{|c|c|c|c|c|c|c|c|c|c|c|}
\hline $\begin{array}{c}\text { CARBON } \\
\text { DIOXIDE } \\
\text { DIS- } \\
\text { SOLVED }\end{array}$ & $\begin{array}{c}\text { ALKA- } \\
\text { LINITY } \\
\text { WAT WH } \\
\text { TOT FET } \\
\text { FIELD }\end{array}$ & $\begin{array}{c}\text { BICAR- } \\
\text { BONATE } \\
\text { WATER } \\
\text { WH FET } \\
\text { FIELD }\end{array}$ & $\begin{array}{c}\text { NITRO- } \\
\text { GEN, } \\
\text { NITRATE } \\
\text { DIS- } \\
\text { SOLVED }\end{array}$ & $\begin{array}{l}\text { HARD- } \\
\text { NESS } \\
\text { TOTAL } \\
\text { (MG } / L\end{array}$ & $\begin{array}{l}\text { HARD- } \\
\text { NESS } \\
\text { NONCARB } \\
\text { WH WAT } \\
\text { TOT FLD }\end{array}$ & $\begin{array}{l}\text { CALCIUM } \\
\text { DIS- } \\
\text { SOLVED }\end{array}$ & $\begin{array}{l}\text { MAGNE- } \\
\text { SIUM, } \\
\text { DIS- } \\
\text { SOLVED }\end{array}$ & $\begin{array}{l}\text { SODIUM, } \\
\text { DIS- } \\
\text { SOLVED }\end{array}$ & $\begin{array}{c}\text { SODIUM } \\
\text { AD- } \\
\text { SORP- } \\
\text { TION }\end{array}$ & \\
\hline $\begin{array}{c}\text { (MG/L } \\
\text { AS CO2) } \\
(00405)\end{array}$ & $\begin{array}{c}\text { MG/L AS } \\
\text { CACO3 } \\
(00410)\end{array}$ & $\begin{array}{c}\text { MG/L AS } \\
\text { HCO3 } \\
(00440)\end{array}$ & $\begin{array}{c}\text { (MG/L } \\
\text { AS N) } \\
(00618)\end{array}$ & $\begin{array}{c}\text { AS } \\
\text { CACO3) } \\
(00900)\end{array}$ & $\begin{array}{c}\text { KG/L AS } \\
\text { CACO3 } \\
(00902)\end{array}$ & $\begin{array}{c}\text { (MG/L } \\
\text { AS CA) } \\
(00915)\end{array}$ & $\begin{array}{c}\text { (MG/L } \\
\text { AS MG) } \\
(00925)\end{array}$ & $\begin{array}{c}\text { (MG/L } \\
\text { AS NA) } \\
(00930)\end{array}$ & $\begin{array}{l}\text { RATIO } \\
(00931)\end{array}$ & $\begin{array}{l}\text { SODIUM } \\
\text { PERCENT } \\
(00932)\end{array}$ \\
\hline
\end{tabular}

$\begin{array}{ccccccccccccc}\text { MAR } & & 2.5 & 2 & 2 & 0.050 & 3 & 2 & 0.80 & 0.20 & 1.1 & 0.3 & 45\end{array}$

WATER-QUALITY DATA, WATER YEAR OCTOBER 1967 TO SEPTEMBER 1968

CON-

TRIB

UTING

$\begin{array}{llllc} & & \text { DRAIN- } & \text { LOGIC } & \text { LAT- } \\ \text { DATE } & & & \\ \text { AGE } & \text { UNIT } & \text { I- } \\ \text { NIME } & \text { COUNTY } & \text { AREA } & \text { CODE } & \text { TUDE }\end{array}$

SOLIDS, NITRO-

$\begin{array}{lllll}\text { POTAS- } & \text { CHLO- } & & \text { FLUO- } & \text { SILICA, SUM OF SOLIDS, GEN, } \\ \text { SIUM, } & \text { RIDE, SULFATE RIDE, } & \text { DIS- } & \text { CONSTI- DIS- NITRATE }\end{array}$

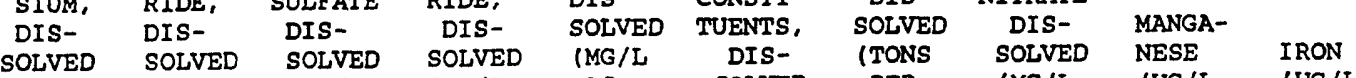

(MG/L (MG/L (MG/L (MG/L AS SOLVED PER (MG/L (UG/L (UG/L

$\begin{array}{cccccccccc}\text { AS K) } & \text { AS CL) } & \text { AS SO4) } & \text { AS F) } & \text { SIO2) } & (\text { MG/L) } & \text { AC-FT) } & \text { AS NO3) } & \text { AS MN). } & \text { AS FE } \\ (00935) & (00940) & (00945) & (00950) & (00955) & (70301) & (70303) & (71851) & (71883) & (71885)\end{array}$

$\begin{array}{cllllllllll}\text { MAR } & \\ 15 \ldots & 0.10 & 2.5 & 1.0 & 0.0 & 0.80 & 8 & 0.01 & 0.20 & 0 & 20\end{array}$

JUN

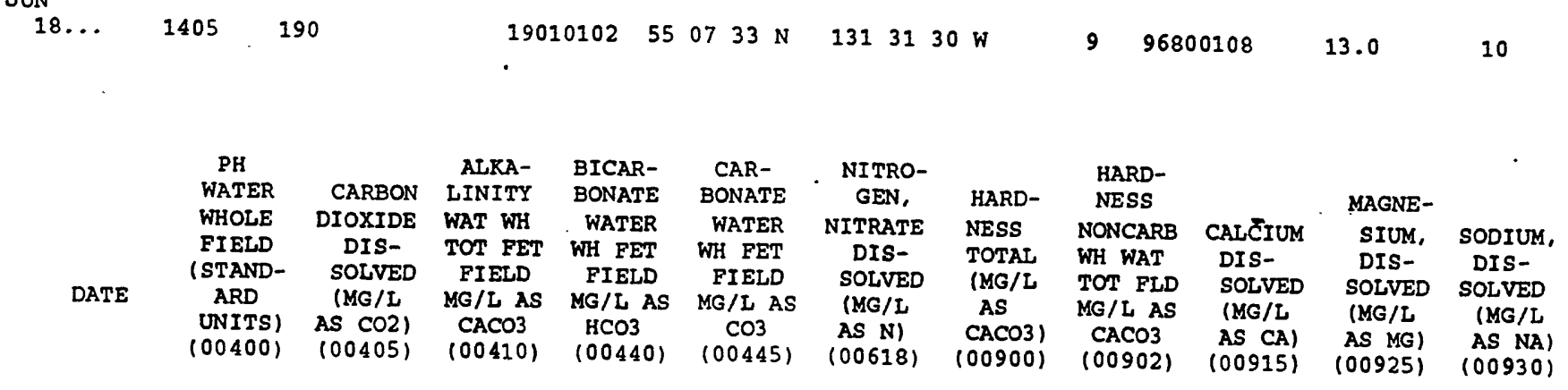

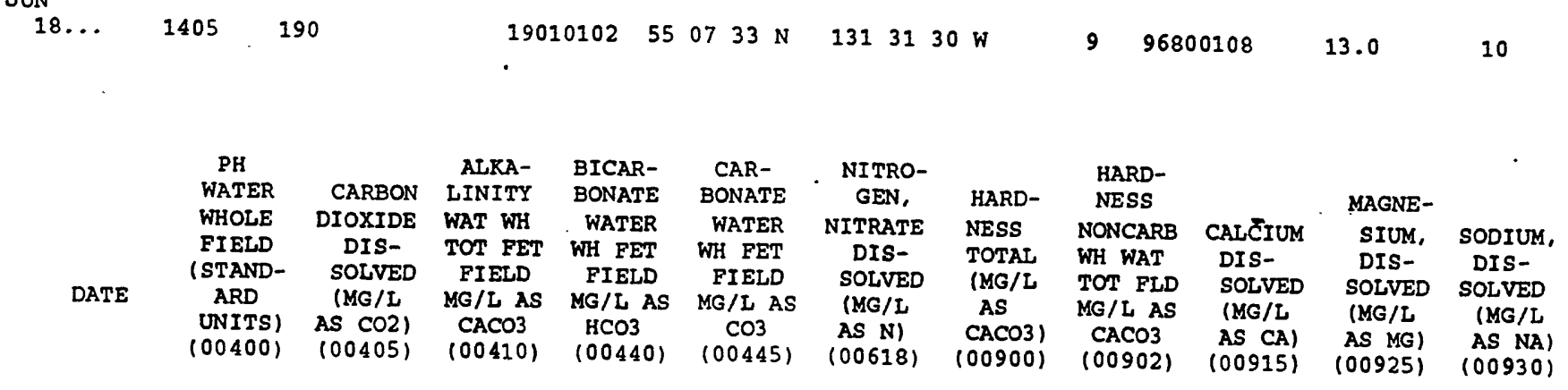

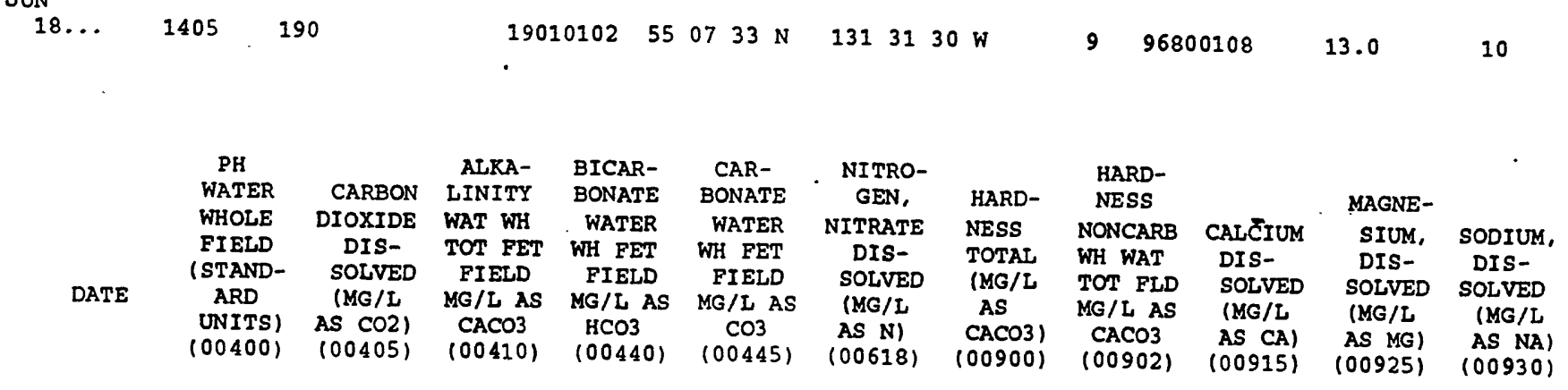

SPE-

$\begin{array}{ccccll}\text { LONG- } & & & & \text { COLOR } & \text { CIFIC } \\ \text { I- } & \text { MEDIUM } & \text { RECORD } & \text { TEMPER- } & \text { (PLAT- } & \text { CON- } \\ \text { TUDE } & \text { CODE } & \text { ATURE } & \text { INUM- } & \text { DUCT- } \\ & & & & \end{array}$

CODE NUMBER WATER COBALT ANCE

$\begin{array}{lll}\text { (DEG C) UNITS) (US/CM) } & (\text { US } \\ (00010) & (00080) & (00095)\end{array}$

JUN

$\begin{array}{lllllllllllll}18 \ldots & 5.9 & 6.0 & 2 & 3 & 0 & 0.020 & 0 & 0 & 0.0 & 0.10 & 1.0\end{array}$


WATER-QUALITY DATA, WATER YEAR OCTOBER 1967 TO SEPTEMBER 1968

\begin{tabular}{|c|c|c|c|c|c|c|c|c|c|c|c|c|}
\hline DATE & TIKE & COUNTY & $\begin{array}{l}\text { CON- } \\
\text { TRIB } \\
\text { UTING } \\
\text { DRAIN- } \\
\text { AGE } \\
\text { AREA }\end{array}$ & $\begin{array}{l}\text { HYDRO- } \\
\text { IOGIC } \\
\text { UNIT } \\
\text { CODE }\end{array}$ & $\begin{array}{c}\text { LAT- } \\
\text { I- } \\
\text { TUDE }\end{array}$ & & $\begin{array}{l}\text { LONG- } \\
\text { I- } \\
\text { TUDE }\end{array}$ & $\begin{array}{l}\text { MEDIUM } \\
\text { CODE }\end{array}$ & $\begin{array}{l}\text { RECORD } \\
\text { NUMBER }\end{array}$ & $\begin{array}{l}\text { TEMPER- } \\
\text { ATURE } \\
\text { WATER } \\
\text { (DEG C) } \\
(00010)\end{array}$ & $\begin{array}{l}\text { COLOR } \\
\text { (PLAT- } \\
\text { INUM- } \\
\text { COBALT } \\
\text { UNITS) } \\
\text { (00080) }\end{array}$ & $\begin{array}{l}\text { SPE- } \\
\text { CIFIC } \\
\text { CON- } \\
\text { DUCT- } \\
\text { ANCE } \\
\text { (US/CM) } \\
(00095)\end{array}$ \\
\hline $\begin{array}{l}\text { UN } \\
18 \ldots .\end{array}$ & 1320 & 190 & & 19010102 & $550611 N$ & 131 & $3340 \%$ & 0 & 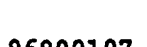 & $1=5$ & & \\
\hline
\end{tabular}

\begin{tabular}{|c|c|c|c|c|c|c|c|c|c|c|c|}
\hline DATE & $\begin{array}{c}\text { PH } \\
\text { WATER } \\
\text { WHOLE } \\
\text { FIELD } \\
\text { (STAND- } \\
\text { ARD } \\
\text { UNITS) } \\
(00400)\end{array}$ & $\begin{array}{c}\text { CARBON } \\
\text { DIOXIDE } \\
\text { DIS- } \\
\text { SOLVED } \\
\text { (MG/L } \\
\text { AS CO2) } \\
(00405)\end{array}$ & $\begin{array}{l}\text { ALKA- } \\
\text { LINITY } \\
\text { WAT WH } \\
\text { TOT FET } \\
\text { FIELD } \\
\text { MG/L AS } \\
\text { CACO3 } \\
(00410)\end{array}$ & $\begin{array}{c}\text { BICAR- } \\
\text { BONATE } \\
\text { WATER } \\
\text { WH FET } \\
\text { FIELD } \\
\text { MG/L AS } \\
\text { HCO3 } \\
(00440)\end{array}$ & $\begin{array}{c}\text { CAR- } \\
\text { BONATE } \\
\text { WATER } \\
\text { WH FET } \\
\text { FIELD } \\
\text { MG/L AS } \\
\text { CO3 } \\
(00445)\end{array}$ & $\begin{array}{c}\text { NITRO- } \\
\text { GEN, } \\
\text { NITRATE } \\
\text { DIS- } \\
\text { SOLVED } \\
\text { (MG/L } \\
\text { AS N) } \\
(00618)\end{array}$ & $\begin{array}{l}\text { HARD- } \\
\text { NESS } \\
\text { TOTAL } \\
\text { (MG/L } \\
\text { AS } \\
\text { CACO3) } \\
(00900)\end{array}$ & $\begin{array}{l}\text { HARD- } \\
\text { NESS } \\
\text { NONCARB } \\
\text { WH WAT } \\
\text { TOT FLD } \\
\text { MG/L AS } \\
\text { CACO3 } \\
(00902)\end{array}$ & $\begin{array}{l}\text { CALCIUM } \\
\text { DIS- } \\
\text { SOLVED } \\
\text { (MG/L } \\
\text { AS CA) } \\
\text { (00915) }\end{array}$ & $\begin{array}{c}\text { MAGNE- } \\
\text { SIUM, } \\
\text { DIS- } \\
\text { SOLVED } \\
\text { (MG/L } \\
\text { AS MG) } \\
\text { (00925) }\end{array}$ & $\begin{array}{l}\text { SODIUM, } \\
\text { DIS- } \\
\text { SOLVED } \\
\text { (MG/L } \\
\text { AS NA) } \\
(00930)\end{array}$ \\
\hline $\begin{array}{l}\text { JUN } \\
18 \ldots\end{array}$ & 6.8 & 5.1 & 16 & 20 & 0 & 0.020 & 15 & 0 & 0.0 & 3.6 & 3.0 \\
\hline DATE & $\begin{array}{c}\text { SODIUM } \\
\text { AD- } \\
\text { SORP- } \\
\text { TION } \\
\text { RATIO } \\
(00931)\end{array}$ & $\begin{array}{l}\text { SODIUM } \\
\text { PERCENT } \\
(00932)\end{array}$ & $\begin{array}{c}\text { POTAS- } \\
\text { SIUM, } \\
\text { DIS- } \\
\text { SOLVED } \\
\text { (MG/L } \\
\text { AS K) } \\
(00935)\end{array}$ & $\begin{array}{l}\text { CHLO- } \\
\text { RIDE, } \\
\text { DIS- } \\
\text { SOLVED } \\
\text { (MG/L } \\
\text { AS CL) } \\
(00940)\end{array}$ & $\begin{array}{l}\text { SULFATE } \\
\text { DIS- } \\
\text { SOLVED } \\
\text { (MG/L } \\
\text { AS SO4) } \\
(00945)\end{array}$ & $\begin{array}{l}\text { FLUO- } \\
\text { RIDE, } \\
\text { DIS- } \\
\text { SOLVED } \\
\text { (MG/L } \\
\text { AS F) } \\
(00950)\end{array}$ & $\begin{array}{l}\text { SILICA, } \\
\text { DIS- } \\
\text { SOLVED } \\
\text { (MG/L } \\
\text { AS } \\
\text { SIO2) } \\
(00955)\end{array}$ & $\begin{array}{l}\text { SOLIDS, } \\
\text { SUM OF } \\
\text { CONSTI- } \\
\text { TUENTS, } \\
\text { DIS- } \\
\text { SOLVED } \\
\text { (MG/L) } \\
(70301)\end{array}$ & $\begin{array}{c}\text { SOLIDS, } \\
\text { DIS- } \\
\text { SOLVED } \\
\text { (TONS } \\
\text { PER } \\
\text { AC-PT) } \\
(70303 \text { ) }\end{array}$ & $\begin{array}{c}\text { NITRO- } \\
\text { GEN, } \\
\text { NITRATE } \\
\text { DIS- } \\
\text { SOLVED } \\
\text { (MG/L } \\
\text { AS NO3) } \\
(71851)\end{array}$ & $\begin{array}{l}\text { IRON } \\
\text { (UG/L } \\
\text { AS FE) } \\
(71885)\end{array}$ \\
\hline
\end{tabular}
JUN

$18 .$.

$0.3 \quad 30$

0.30

6.4

0.0

0.0

3.4

27

0.04

0.10

90 


\begin{tabular}{|c|c|c|c|c|c|c|c|c|c|c|c|}
\hline DATE & $\begin{array}{l}\text { SODIUM } \\
\text { PERCENT } \\
(00932)\end{array}$ & $\begin{array}{l}\text { POTAS- } \\
\text { SIUM, } \\
\text { DIS- } \\
\text { SOLVED } \\
\text { (MO/L } \\
\text { AS X) } \\
(00935)\end{array}$ & $\begin{array}{l}\text { CHLO- } \\
\text { RIDE, } \\
\text { DIS- } \\
\text { SOLVED } \\
\text { (MG/L } \\
\text { AS CL) } \\
(00940)\end{array}$ & $\begin{array}{l}\text { SULFATE } \\
\text { DIS- } \\
\text { SOLVED } \\
\text { (MG/L } \\
\text { AS SO4) } \\
\text { (00945) }\end{array}$ & $\begin{array}{l}\text { FLUO- } \\
\text { RIDE, } \\
\text { DIS- } \\
\text { SOLVED } \\
(\text { MG/L } \\
\text { AS F) } \\
(00950)\end{array}$ & $\begin{array}{l}\text { SILICA, } \\
\text { DIS- } \\
\text { SOLVED } \\
\text { (MG/L } \\
\text { AS } \\
\text { SIO2) } \\
(00955)\end{array}$ & $\begin{array}{l}\text { SOLIDS, } \\
\text { SUM OF } \\
\text { CONSTI- } \\
\text { TUENTS, } \\
\text { DIS- } \\
\text { SOLVED } \\
\text { (MG/L) } \\
\text { (70301) }\end{array}$ & $\begin{array}{c}\text { SOLIDS, } \\
\text { DIS- } \\
\text { SOLVED } \\
\text { (TONS } \\
\text { PER } \\
\text { AC-FT) } \\
\text { (70303) }\end{array}$ & $\begin{array}{c}\text { NITRO- } \\
\text { GEN, } \\
\text { NITRATE } \\
\text { DIS- } \\
\text { SOLVED } \\
\text { (MG/L } \\
\text { AS NO3) } \\
\text { (71851) }\end{array}$ & $\begin{array}{l}\text { MANGA- } \\
\text { NESE } \\
\text { (UG/L } \\
\text { AS MN) } \\
\text { (71883) }\end{array}$ & $\begin{array}{l}\text { IRON } \\
\text { (UG/L } \\
\text { AS FE) } \\
(71885)\end{array}$ \\
\hline
\end{tabular}

MAR

$\begin{array}{lllllllllllll}08 \ldots & 28 & 0.60 & 5.0 & 2.0 & 0.70 & 3.8 & 29 & 0.04 & 0.30 & 0 & 100\end{array}$

WATER-QUALITY DATA, WATER YEAR OCTOBER 1965 TO SEPTEMBER 1966

\begin{tabular}{|c|c|c|c|c|c|c|c|c|c|c|}
\hline DATE & COUNTY & $\begin{array}{l}\text { CON- } \\
\text { TRIB } \\
\text { UTING } \\
\text { DRAIN- } \\
\text { AGE } \\
\text { AREA }\end{array}$ & $\begin{array}{l}\text { HYDRO- } \\
\text { LOGIC } \\
\text { UNIT } \\
\text { CODE }\end{array}$ & $\begin{array}{l}\text { LAT- } \\
\text { I- } \\
\text { TUDE }\end{array}$ & $\begin{array}{l}\text { LONG- } \\
\text { I- } \\
\text { TUDE }\end{array}$ & $\begin{array}{l}\text { MEDIUM } \\
\text { CODE }\end{array}$ & $\begin{array}{l}\text { RECORD } \\
\text { NUMBER }\end{array}$ & $\begin{array}{l}\text { COLOR } \\
\text { (PLAT- } \\
\text { INUM- } \\
\text { COBALT } \\
\text { UNITS) } \\
\text { (00080) }\end{array}$ & $\begin{array}{l}\text { SPE- } \\
\text { CIFIC } \\
\text { CON- } \\
\text { DUCT- } \\
\text { ANCE } \\
\text { (US/CM) } \\
\text { (O0095) }\end{array}$ & $\begin{array}{c}\text { PH } \\
\text { WATER } \\
\text { WHOLE } \\
\text { FIELD } \\
\text { (STAND- } \\
\text { ARD } \\
\text { UNITS) } \\
\text { (OO400) }\end{array}$ \\
\hline
\end{tabular}

MAR

$03 . . .-190$

$19010102550611 \mathrm{~N} \quad 1313349 \mathrm{~W}$

996600034

30

48

7.1

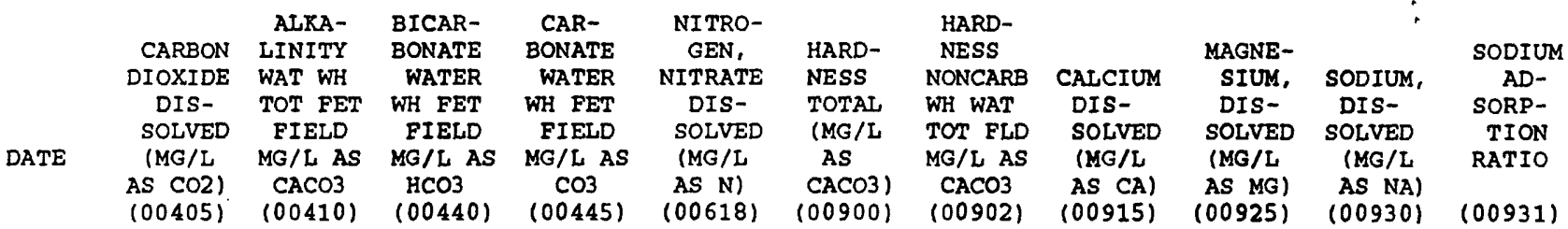

MAR

$03 \ldots$

13

16

0

0.160

15

20.80

3.2

2.9

0.3

SODIUM PERCENT (00932)

$\begin{array}{ccccc} & & & & \\ \text { POTAS- } & \text { CHLO- } & & \text { FLUO- } & \text { SILICA, } \\ \text { SIUM, } & \text { RIDE, } & \text { SULFATE } & \text { RIDE, } & \text { DIS- } \\ \text { DIS- } & \text { DIS- } & \text { DIS- } & \text { DIS- } & \text { SOLVED } \\ \text { SOLVED } & \text { SOLVED } & \text { SOLVED } & \text { SOLVED } & \text { (MG/L } \\ (M G / L & (M G / L & (M G / L & (M G / L & \text { AS } \\ \text { AS K) } & \text { AS CL) } & \text { AS SO4) } & \text { AS F) } & \text { SIO2) } \\ (00935) & (00940) & (00945) & (00950) & (00955)\end{array}$

SOLIDS,

SUM OF, SOLIDS. CONSTITUENTS, DISSOLVED (MG/L) (70301) SOLIDS,
DIS-
SOLVED (TONS PER AC-FT) (70303)
NITROGEN, NITRATE DISSOLVED (MG/L AS NO3) (71851)
MANGANESE IRON IUG/L (UG/L AS MN) AS FE) (71883) (71885)
MAR

$03 .$.

6.0

3.8

0.10

3.9

30

0.04

0.70

0

60 
WATER-QUALITY DATA, WATER YEAR OCTOBER 1960 TO SEPTEMBER 1961

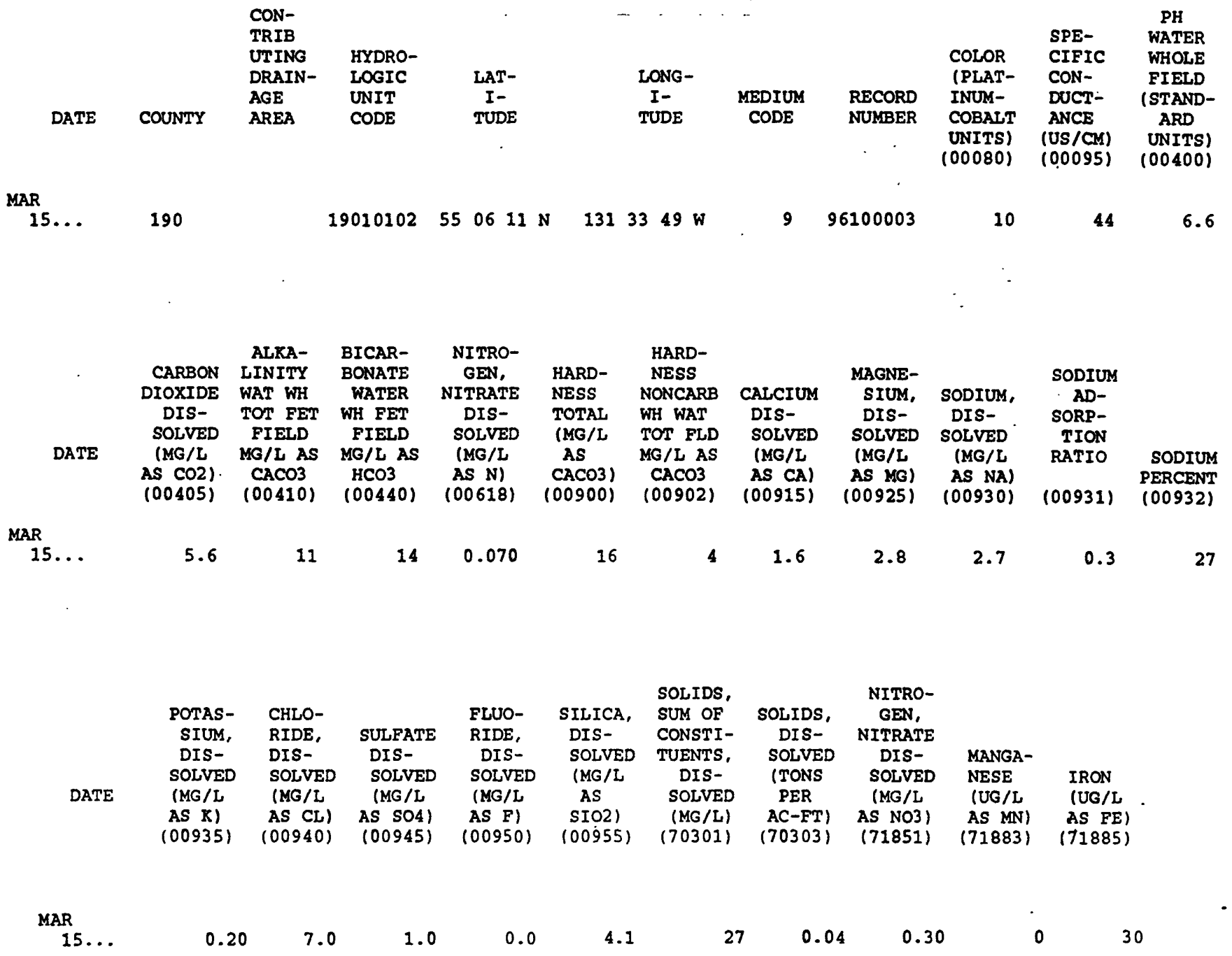

WATER-QUALITY DATA，WATER YEAR OCTOBER 1962 TO SEPTEMBER 1963

CON-

TRIB

UTING HYDRODRAIN- LOGIC AGE UNIT

DATE COUNTY AREA CODE

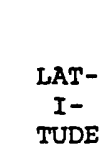

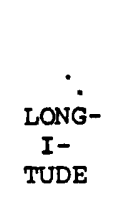




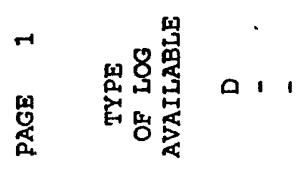

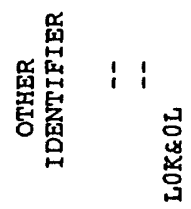

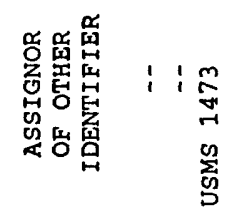

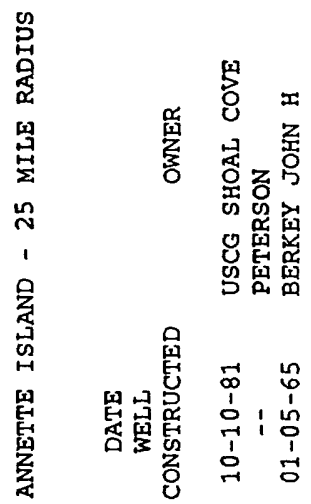

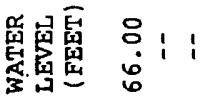

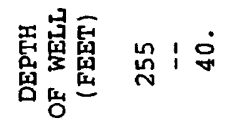

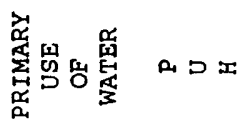

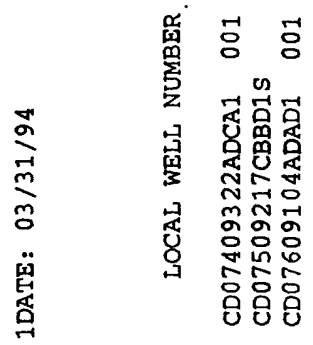


- of gravel which, in turn, is overlain by about 4 feet of organically rich muck. Near the middle of the gravel layer is a wedge of silty peat containing fragments of partly lignitized wood as much as 2 feet long. The gravel at this locality, in contrast to that of the other localities, is well sorted, as shown by a sorting coefficient of 1.4 , and most of the particles are subrounded to well rounded. About 80 percent of the sample is larger than $4 \mathrm{~mm}$, and the mediun size is about $7 \mathrm{~mm}$.

Differential thermal analysis of a clay sample from locality 36-1 shows that the clay is illite, a common constituent of both marine and glacial deposits (Grim, 1955, p. 484).

\section{ORIGIN}

The origin of the deposits herein referred to as raised beaches is reflected in their beltlike pattern of distribution and stratigraphy. Based on Chapin's suggestion $(1918$, p. 99) that the Metlakatla peninsula is a wave-cut bench, raised beach deposits are logically expected in this area. A more complex origin was postulated by Buddington $(1927$, p. 51 ) who suggested that the peninsula is largely the product of subaerial erosion and glaciation subsequently modified by marine erosion between successive uplifts. Periods of stable sea level would allow time for the accumulation of beach deposits, and uplift would preserve such deposits by removing them from the zone of wave erosion.

At least part of the raised beach deposits is derived by wave and tidal current erosion of marine or glaciomarine deposits. Indication of marine origin is provided by fossils, such as fragments of clams, snails, and barnacles in samples of silty clay from drill hole 2 at a depth of 11-14 feet. However, the clay contained no microfossils. Similar silty clay was penetrated in drill holes 1 and 3 , but no samples were collected; hence, the presence or absence of fossils in the deposits at these sites is not known.

Modern beach deposits on the Metlakatla peninsula appear to consist of both locally derived and exotic fragments. The older raised beach deposits, however, apparently consist of material derived mainly from glaciomarine and glacial deposits that have been reworked by wave and tidal current action. Modern beach gravel on Prince of Wales Island has been described by Sainsbury (1961, p. 332) who points out that the gravel is rounded and unstriated and that most of the rock-flour matrix has been removed. Sainsbury further states that typical glacial deposits could probably be found at shallow depth beneath many of the beaches. Material described in the logs of drill holes in Metlakatla peninsula suggests glacial material such as the hardpan noted in drill hole 3. However, no striated or faceted rock particles were recovered during test drilling nor were any noted in surface outcrops.

Information on uplift required to elevate the raised beach deposits above the zone of wave erosion, thus preserving them, is provided by Twenhofel (1952, p. 523-548) who reviewed and summarized the literature relating to shoreline changes along the Pacific coast of Alaska. Most of his evidence for uplift is based on fossil-bearing marine deposits, commonly derived from glacial and glaciomarine material and very similar to those in the Metlakatla peninsula. Twenhofel describes deposits that have been elevated from a few to several hundred feet above sea level and cites evidence obtained by previous workers to show that uplift has amounted to 500 feet or perhaps more in the Portland Canal and Juneau areas.

Hicks and Shofnos (1965, p. 3315-3320) present sea-level data to show that nearly all southeastern Alaska is rising. The center of uplift is in the vicinity of Glacier Bay about 320 miles north of Annette Island. At Ketchikan, only 15 miles north of Annette Island, uplift amounts to about 3 centimeters per century. Uplift on nearby Gravina Island has been as much as $\mathbf{8 0}$ feet as shown by marine fossils in blue clay and gravel at that altitude (Chapin, 1918, p. 99). Uplift can take place suddenly and dramatically as shown by more than 7 feet of uplift associated with the Alaskan earthquake of March 27, 1964 (Grantz and others, 1964, p. 4).

\section{WATER-SUPPLY POTENTIAL}

With average precipitation of 117 inches fairly well distributed throughout the year, the raised beach deposits on Metlakatla peninsula should receive nearly continuous recharge. However, the several feet of overlying muck are poorly permeable; thus the rate of recharge may be rather slow.

During an extended dry period the beach deposits at higher altitudes would drain first. Therefore, the most favorable sites for ground water from these deposits are in low areas but above the tidal range to eliminate the danger of contamination by salt water. Infiltration galleries in the raised beach deposits beside or beneath streams would probably be the best means of development. Horizontal galleries in trenches reaching bedrock and perpendicular to the direction of ground-water flow would intercept the greatest amount of water and would, therefore, provide the greatest yield. Methods of installing and maintaining infiltration galleries for developing shallow ground-water supplies have been described by Feulner (1964).

No analyses of water from the raised beach deposits were made during the study of the Metlakatla peninsula, but the chemical quality is probably good. Because the raised beach deposits are near the surface, they are subject to pollution; thus the area around an infiltration gallery would have to be protected. Dark color derived from decomposition of vegetation in the muskeg and muck may be a problem, although the color might be eliminated by special treatment.

\section{REFERENCES}

Buddington, A. F., 1927, Abandoned marine benches in southeastern Alaska: Am. Jour. Sci, 5th ser., v. 13, p. 45-52.

Chapin, Theodore, 1918, The structure and stratigraphy of Gravina and Revillagigedo Islands, Alaska: U.S. Geol. Survey Prof. Paper 120-D, p. 83-100. 
Table 1.-Driller's logs of drill holes penetrating raised beach deposits [Logs provided by A. J. Lappi, Federal Aviation Administration]

\begin{tabular}{|c|c|}
\hline $\begin{array}{l}\text { Thickness } \\
\text { (feet) }\end{array}$ & $\begin{array}{l}\text { Depth } \\
\text { (feet) }\end{array}$ \\
\hline \multicolumn{2}{|l|}{ Drill hole 1-Altitude 10 feet (altimeter) } \\
\hline 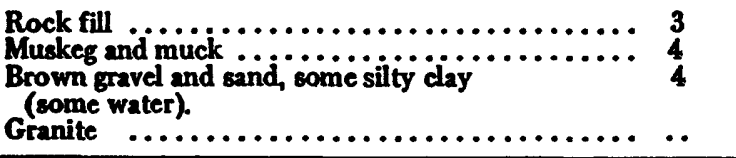 & $\begin{array}{r}0-3 \\
3-7 \\
7-11 \\
11\end{array}$ \\
\hline \multicolumn{2}{|l|}{ Drill hole 2-Altitude 15 feet (altimeter) } \\
\hline 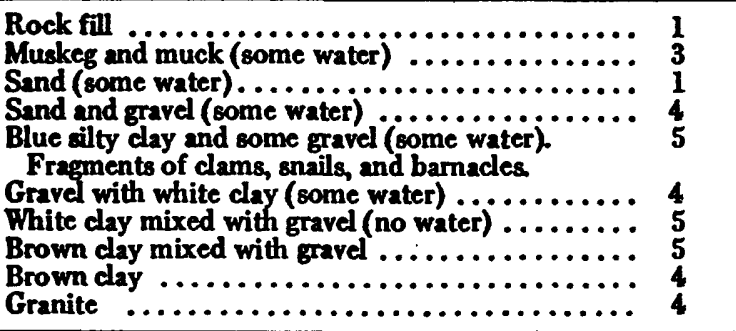 & $\begin{array}{r}1-2 \\
2-5 \\
5-6 \\
6-10 \\
10-15\end{array}$ \\
\hline \multicolumn{2}{|l|}{ Drill hole 3-Altitude 50 feet (altimeter) } \\
\hline $\begin{array}{l}\text { Rock fill } \ldots \ldots \text {. } \\
\text { Muskeg and muck (some water) } \ldots \ldots \ldots \ldots \ldots \ldots \ldots \ldots \\
\text { Gravel (some water) } \ldots \ldots \ldots \ldots \ldots \ldots \ldots \ldots \ldots \ldots \ldots \ldots\end{array}$ & $\begin{array}{r}0-2 \\
2-8 \\
8-9 \\
9-10 \\
10-13 \\
13-21 \\
21-24 \\
24-28 \\
28\end{array}$ \\
\hline
\end{tabular}

distances. At locality 21-5 (fig. 1) raised beach deposits, about 10 feet thick, exposed about 40 feet above tide level, consist mainly of interbedded layers and lenses of gravel, sand, silt, and clay containing cobbles up to 8 inches in diameter. Visual estimation indicates that about two-thirds of the gravel and cobbles are subangular and about one-third are subrounded to rounded. The upper 2 feet of the exposure is heavily stained by iron oxide and organic matter; within this interval a few layers less than 1 inch thick are weakly cemented by iron oxide. Size analysis of a grab sample from this locality shows that about 50 percent of the sample is larger than $4 \mathrm{~mm}$ (millimeters) in diameter (fig. 2). The particle-size distribution curve (fig. 2) shows that sorting is poor.

At locality 35-1 the raised beach deposits consist of 4-6 feet of sandy gravel overlying silty and clayey bluish-gray sand of unknown thickness. Analysis of a sample (35-1A) from the gravel shows that sorting is poor and that about 55 percent of the sample is larger than $4 \mathrm{~mm}$; the median particle size is between 5 and $6 \mathrm{~mm}$. The larger particles are subangular to well rounded; perhaps 30-50 percent subangular. Analysis of a sand sample (35-1B) from this locality shows that the sand has a sorting coefficient of 1.7 , indicating that it is well sorted. About 50 percent of the sample is in the fine and very fine size range; the medium size is $0.075 \mathrm{~mm}$.

The stratigraphic sequence at locality 36-1 consists of an unknown thickness of bluish-gray clay overlain by about 6 feet

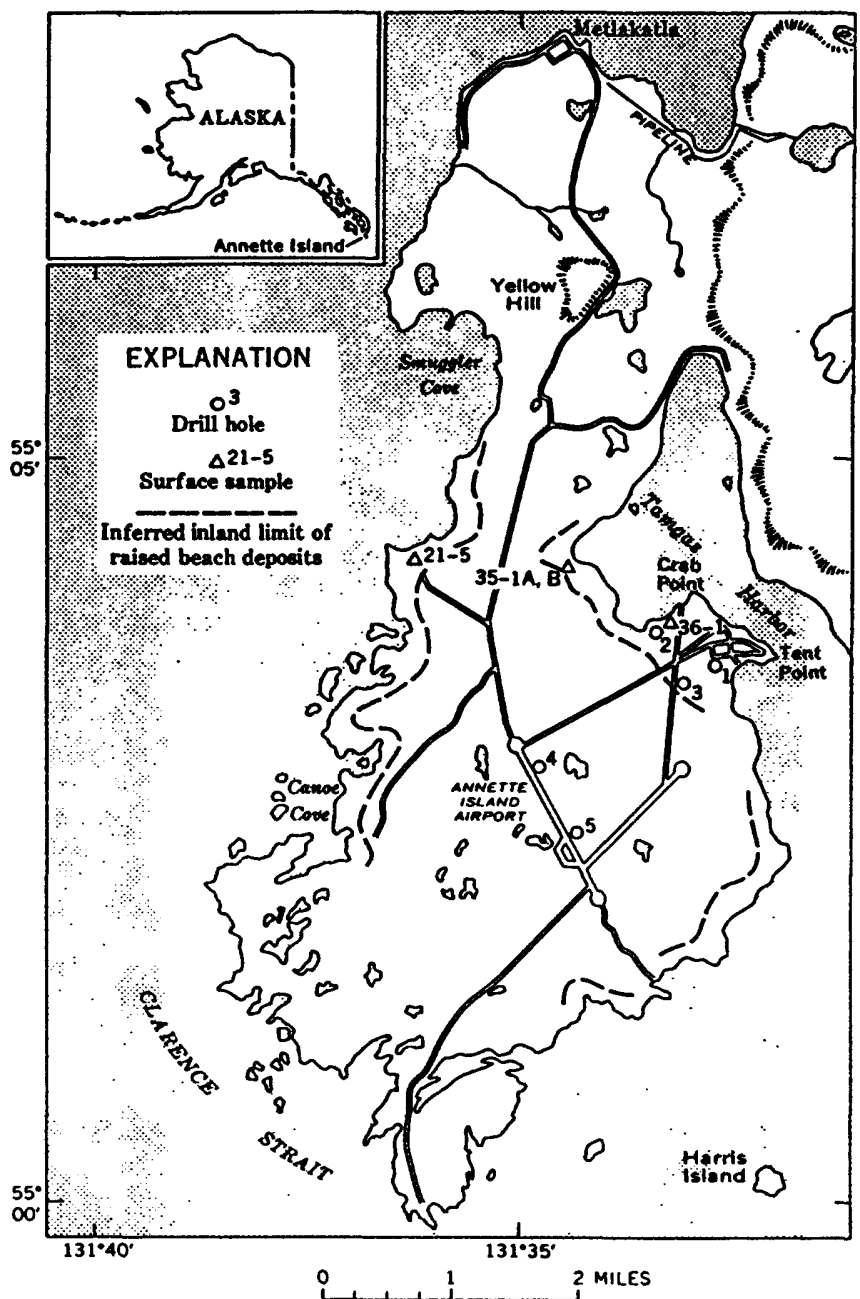

Figure 1.-Map of the Metlakatla peninsula, showing location of drill holes and surface samples, and inferred limit of raised beach deposits.

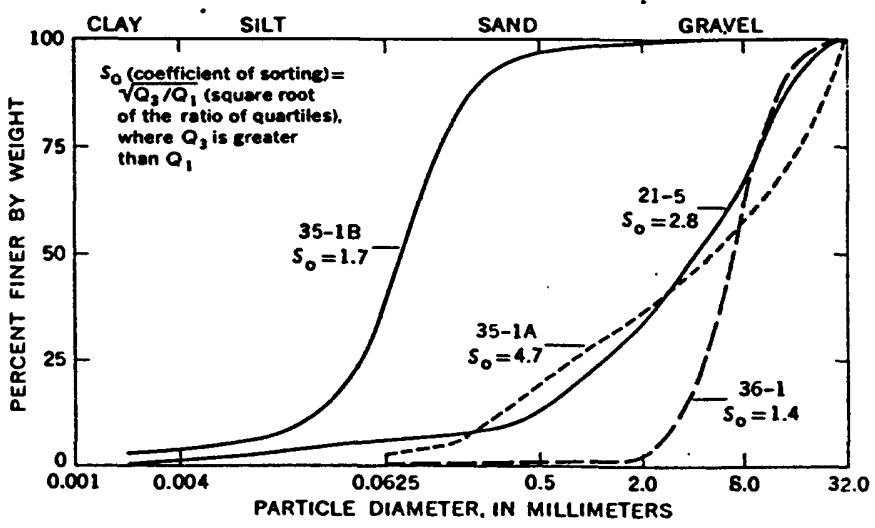

Figure 2-Particle-size distribution of surface samples from raised beach deposits. See figure $I$ for sample localities. 


\title{
RAISED BEACH DEPOSITS AND THEIR GROUND-WATER POTENTIAL IN THE SOUTHERN PART OF THE METLAKATLA PENINSULA, ANNETTE ISLAND, ALASKA
}

\author{
BY MELVIN V. MARCHER, Oklahoma City, Okla.
}

Work done in cooperation with the Federal Aviation Administration

\begin{abstract}
Interbedded layers of gravel and sand on the Metlakatia peninsula are interpreted as raised beach deposits derived largely from marine, glaciomarine, and glacial deposits reworked by waves and tidal currents. Such deposits and similar deposits elsewhere in southeastern Alaska may be potential sources of small ground-water supplies.
\end{abstract}

Ground-water supplies in bedrock of southeastern Alaska, which are described in a companion paper (Marcher, 1971) (p. D198-D201, this chapter), may be difficult and costly to locate. Thus, in some parts of the region the search for ground water is most logically directed toward locating alluvial or similar deposits sufficiently thick and permeable to store and yield water. Layers of gravel and sand that make up ancient beach deposits in some areas may be potential sources of water. These deposits are also potential sources of aggregate materials in a region where bedrock is almost everywhere at or near the surface.

As part of a pioject to locate water supplies on the Metlakatla peninsula, the raised beach deposits were studied briefly. Drill holes, scattered surface exposures, and excavations near Crab Point provide information on the thickness, stratigraphy, and general lithology of the deposits. Size analyses of surface samples and differential thermal analysis of a clay sample were made in the laboratories of the U.S. Geological Survey, Denver, Colo.

\section{DISTRIBUTION AND THICKNESS}

In regard to the inferred distribution of the raised beach deposits, L. A. Yehle reports (written commun., Nov. 1970) as follows:

\footnotetext{
* * a 1:20,000 scale topographic map of the southern part of Metlakatla peninsula prepared in 1940 by the U.S. Geological Survey * * * shows several levels of benches or terraces * * *. Altitudinally, the lowest cluster of levels is up to about 30 to 35 feet above msl (mean sea
}

level) and many others have their inner margin about 25 feet above ms. An intermediate cluster of bench or terrace levels is between about 50 and 55 feet above mo. A much less well developed, and higher, cluster of levels is between about 95 and 110 feet above msl. Between all these clusters of levels there are other scattered benches or terraces.

\section{Yehle also notes (written commun., Nov. 1970) as follows:}

At Metlakatla town, Dick Lemke and I noted sand and gravel underlying the ground surface up to an altitude of at least 50 feet above mean sea level. These (presumably) wave and tidal currentworked materials well may extend to slightly higher altitudes. In the central part of town there is a hint of a very minor break-in slope at about 35 feet above msl. In the western part of town this altitude is at the lower margin of a more prominent break-in slope. However, in the latter area, no data on materials are available.

Drill-hole records and scattered outcrops along streams in the southern part of the peninsula show that at least some of the benches noted by Yehle are underlain by raised beach deposits. The highest known raised beach deposits underlie a terrace at the 50 -foot level at the site of drill hole 3 . The deposits are absent at higher levels in at least part of the area as shown by the logs of drill holes 4 and 5 (95 and 115 feet above sea level, respectively); both drill holes passed directly from muck into bedrock.

Drill-hole logs (table 1) show that raised beach deposits are as much as 5 feet thick. Exposures near the modern beach and in stream banks near the narrow part of the peninsula show that the deposits are at least 10-12 feet thick in this part of the area. Similar thicknesses were seen in construction excavations near Tent and Crab Points and in nearby surface outcrops.

\section{LITHOLOGY}

Drill-hole $\operatorname{logs}$ and surface exposures show the general lithology and stratigraphy of the raised beach deposits and indicate that lateral changes in lithology take place over short 


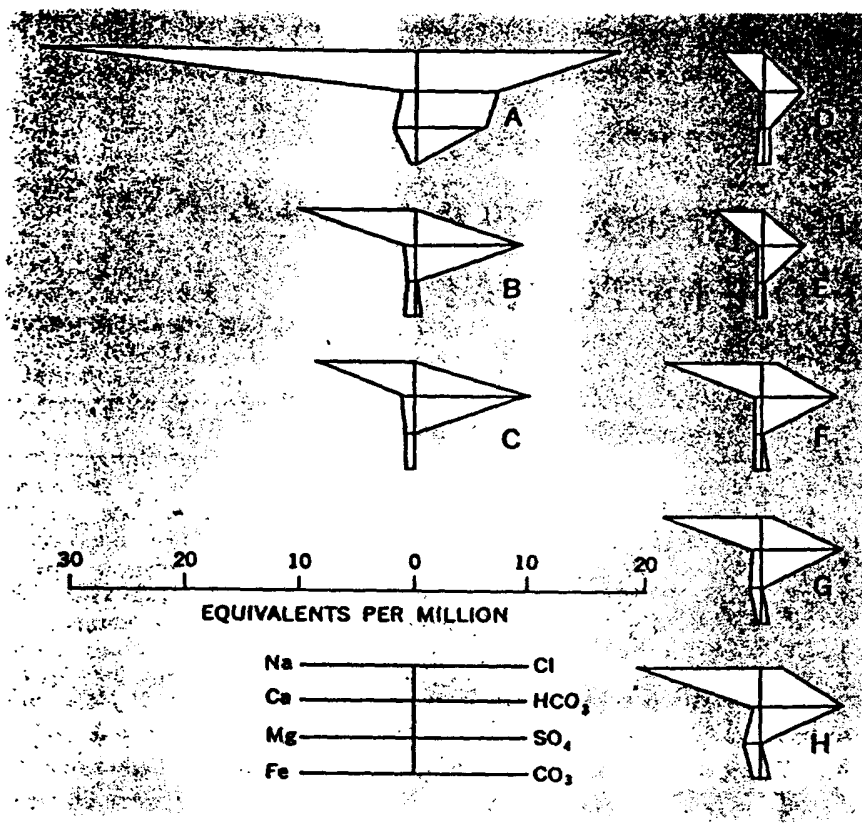

Figure 3.-Chemical characteristics of ground water from Metlakatla peninsula. $A$, drill hole $1 ; B$, drill hole $2 ; C$, drill hole $3 ; D$, drill hole 5 , 109-121 feet; $E$, drill hole 5, 183-209 feet; $F$, drill hole 5, 272-282 feet; G, drill hole 5, 297-305 feet; H, test well, composite of all producing zones.

Samples from drill holes 2 and 3 and the composite sample from the test well show that the water is a sodium bicarbonate type.

The high sodium, magnesium, sulfate, and chloride contents in water from drill hole 1 suggest admixture of sea water with normal ground water.

During drilling of the test well, samples were collected from water-bearing zones at depths of 109-121, 183-209, 272-282, and 297-305 feet. These samples were collected after the hole had been pumped to remove all drilling fluids, thereby assuring a representative water sample. After each sample was collected, the water-bearing zone was sealed with cement and drilling continued. Thus, each sample from above 305 feet represents water from a single fracture zone. Samples from below a depth of 305 feet are a composite of all water-bearing zones penetrated by the well.

Chemical analyses show that the concentration of some constituents changed little with depth (table 1). Other constituents, particularly sodium and bicarbonate, increased rather markedly with depth. These increases are presumably the result of the water being in contact with the rock longer as it slowly moves downward or incomplete flushing of sea water from deeper crevices.

Because of the potential hazard of salt-water intrusion with progressive lowering of the water level in the test well during pumping, samples were collected intermittently between April and October 1965 and tested for chloride content. Figure 4

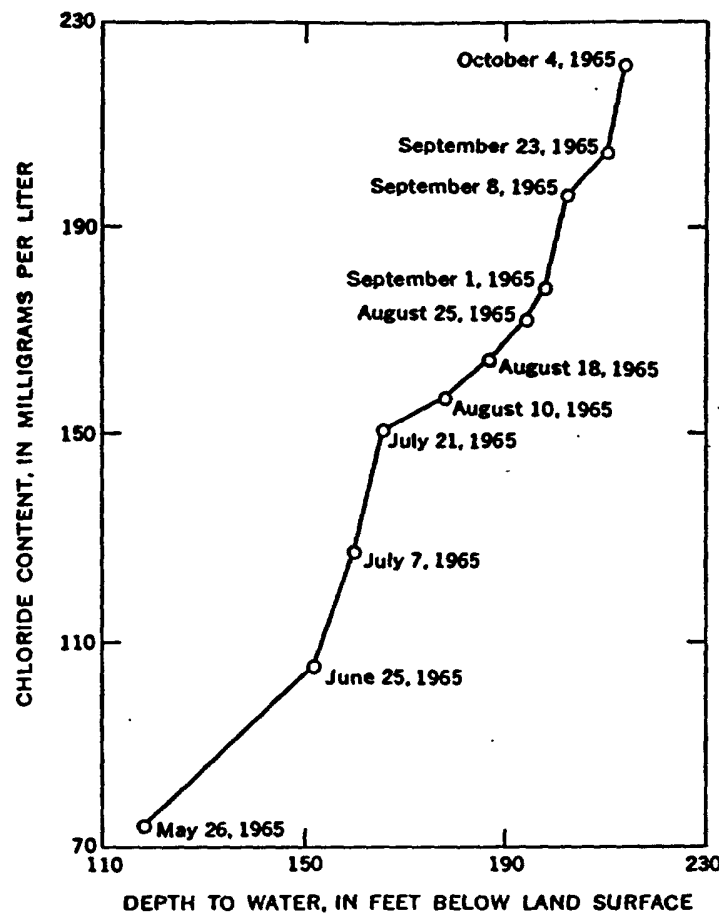

Figure 4.-Increase of chloride content of water in test well with increasing drawdown.

shows that the average chloride content increase was about 15 $\mathrm{mg} / \mathrm{l}$ for every 10 feet of drawdown.

\section{CONCLUSIONS}

Four out of five drill holes produced small amounts of water from bedrock in the Metlakatla peninsula; geologically similar terranes in southeastern Alaska also might be expected to provide small supplies. Fractured zones at depths of less than 150 feet are more likely to provide a continuing supply of water because recharge can take place more rapidly. Although the test well drilled during this study cannot be pumped continuously at a rate of $35 \mathrm{gpm}$, it will provide that amount intermittently. However, drawdown must be carefully controlled to prevent encroachment of salt water. Additional supplies may be available from fracture zones, which can be located only by test drilling.

\section{REFERENCES}

Berg, H. C., 1969, Preliminary geologic map of Annette Island, Alaska: U.S. Geol. Survey open-file rept., 1 sheet.

Buddington, A. F., and Chapin, Theodore, 1929, Geology and mineral deposits of southeastern Alaska: U.S. Geol. Survey Bull. 800, 398 p.

Marcher, M. V., 1971, Raised beach deposits and their ground-water potential in the southern part of the Metlakatla peninsula, Annette Island, Alaska, in Geological Survey Research 1971: U.S. Geol. Survey Prof. Paper 750-D, p. D202-D205.

Stiff, H. A., Jr., 1951, The interpretation of chemical water analysis by means of patterns: Jour. Petroleum Technology, v. 3, no. 10, sec. 1 , p. 15-16; sec. 2, p. 3. 
yield of $100 \mathrm{gpm}$ could not be maintained without excessive drawdown.

Subsequent to the recovery test a pump was installed in the well and operated almost continuously at a rate of $35 \mathrm{gpm}$ for more than 3 months. Water-level measurements made during this period, plotted against time, are shown in figure 2. Examination of the drawdown curve shows that from a level of 127 feet shortly after pumping started, the water level declined to 206 feet after 100 days of pumping. Total drawdown from static level was 125 feet.

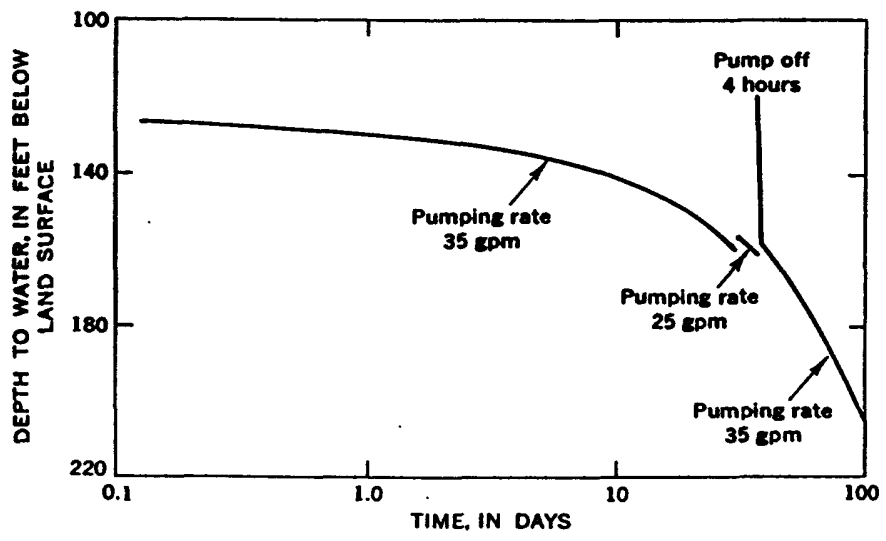

Figure 2-Drawdown in the test well after pumping 100 days. Water level at start of pumping was 81 feet.
During the 3-month pumping period, the rate of drawdown was far in excess of that estimated on the basis of the test. Apparently the water-yielding zones are separated from one another and from surface recharge by considerable thicknesses of unfractured rock so that when they are drained of their stored water, replenishment takes place slowly. Hydrologic boundaries undoubtedly are present, because the fracture zones are not continuous and because the degree of fracturing along individual zones differs from place to place.

\section{Chemical quality}

At least one sample. of water for chemical analysis was collected from each drill hole except number 4, and samples from four of the water-bearing zones in the test well were analyzed to determine variations in chemical quality with depth. Several samples were collected from the completed well after different periods of pumping and analyzed to determine changes in chemical quality that would indicate salt-water intrusion. The results of the analyses are given in table $l$.

By plotting the results of the chemical analyses according to a method devised by Stiff (1951, p. 15-16), the gross chemical characteristics of the water can be compared as shown in figure 3 .

Table 1.-Chemical analyses of ground water from Metlakatla peninsula, Annette Island, Alaska

[All analyses made by U.S. Geological Survey. Results in milligrams per liter except where indicated]

\begin{tabular}{|c|c|c|c|c|c|c|c|c|c|c|c|c|}
\hline $\begin{array}{c}\text { Source } \\
\text { of } \\
\text { water }\end{array}$ & $\begin{array}{c}\text { Date } \\
\text { of } \\
\text { collection }\end{array}$ & $\begin{array}{c}\text { Silica } \\
\left(\mathrm{SiO}_{2}\right)\end{array}$ & $\begin{array}{l}\text { Iron } \\
(\mathrm{Fe})\end{array}$ & $\begin{array}{c}\text { Calcium } \\
\text { (Ca) }\end{array}$ & $\begin{array}{l}\text { Magne- } \\
\text { sium } \\
\text { (Mg) }\end{array}$ & $\begin{array}{l}\text { Sodium } \\
\text { (Na) }\end{array}$ & \multicolumn{2}{|c|}{ 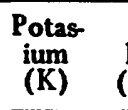 } & $\begin{array}{c}\text { Bicar- } \\
\text { bonate } \\
\left(\mathrm{HCO}_{3}\right)\end{array}$ & $\begin{array}{c}\text { Carbon- } \\
\text { ate } \\
\left(\mathrm{CO}_{3}\right)\end{array}$ & $\begin{array}{c}\text { Sulfate } \\
\left(\mathrm{SO}_{4}\right)\end{array}$ & $\begin{array}{c}\text { Chloride } \\
\text { (Cl) }\end{array}$ \\
\hline Drill hole 1. & 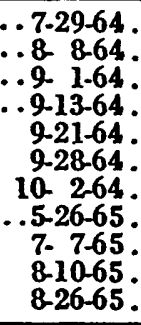 & 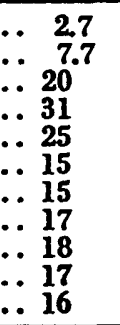 & $\begin{array}{l}0.43 \\
.60 \\
.40 \\
.73 \\
.27 \\
.25 \\
.04 \\
.29 \\
.02 \\
.00 \\
.2\end{array}$ & $\begin{array}{c}12 \\
6.4 \\
12 \\
7.2 \\
1.6 \\
1.6 \\
.8 \\
.0 \\
.0 \\
.0 \\
4\end{array}$ & $\begin{array}{r}14 \\
.5 \\
1.2 \\
3.2 \\
1.9 \\
2.4 \\
1.9 \\
7.1 \\
4.4 \\
3.9 \\
2.6\end{array}$ & $\begin{array}{r}720 \\
220 \\
200 \\
89 \\
105 \\
193 \\
200 \\
235 \\
276 \\
300 \\
300\end{array}$ & \multicolumn{2}{|c|}{$\begin{array}{r}2.2 \\
.8 \\
.3 \\
1.7 \\
1.0 \\
6.7 \\
.6 \\
8.5 \\
9.2 \\
9.0 \\
8.8\end{array}$} & $\begin{array}{l}471 \\
551 \\
558 \\
235 \\
215 \\
404 \\
451 \\
493 \\
480 \\
487 \\
502\end{array}$ & $\begin{array}{r}24 \\
12 \\
0 \\
4 \\
12 \\
11 \\
17 \\
30 \\
22 \\
19 \\
18 .\end{array}$ & $\begin{array}{c}327 \\
7.2 \\
4.8 \\
6.1 \\
7.2 \\
3.8 \\
4.3 \\
6.7 \\
25 \\
16 \\
23\end{array}$ & $\begin{array}{c}642 \\
9.2 \\
5.7 \\
12 \\
14 \\
24 \\
42 \\
74 \\
125 \\
155 \\
172 \\
\end{array}$ \\
\hline $\begin{array}{c}\text { Source } \\
\text { of } \\
\text { water }\end{array}$ & $\begin{array}{c}\text { Date } \\
\text { of } \\
\text { collection }\end{array}$ & $\begin{array}{l}\text { Fluo- } \\
\text { ride } \\
\text { (F) }\end{array}$ & $\begin{array}{l}\text { Nitrate } \\
\left(\mathrm{NO}_{3}\right)\end{array}$ & $\begin{array}{c}\text { Dissolved } \\
\text { solids } \\
\text { (calcu- } \\
\text { lated) }\end{array}$ & $\begin{array}{c}\text { Hard- } \\
\text { ness } \\
\mathrm{CaCO}_{3}^{25}\end{array}$ & \multicolumn{2}{|c|}{$\begin{array}{l}\text { Specific } \\
\text { conduct- } \\
\text { ance } \\
\text { (micro- } \\
\text { mhos) at } \\
25^{\circ} \mathrm{C}\end{array}$} & $\begin{array}{l}\text { pH } \\
\text { units) }\end{array}$ & $\begin{array}{l}\text { Color } \\
\text { (Pt-Co } \\
\text { scale } \\
\text { units) }\end{array}$ & & Remar & \\
\hline \multirow[t]{2}{*}{$\begin{array}{l}\text { Drill hole } \mathbf{1} \\
\mathbf{3} \\
\mathbf{5}\end{array}$} & $\begin{array}{r}7-29-64 \\
8-8-64 \\
9-1-64 \\
9-13-64 \\
9-21-64 \\
9-28-64 \\
10-2-64 \\
5-26-65 \\
7-7-65 \\
8-10-65\end{array}$ & 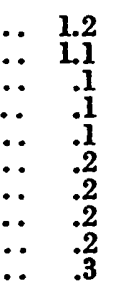 & $\begin{array}{r}0.2 \\
.3 \\
.8 \\
.6 \\
1.2 \\
1.0 \\
.9 \\
.3 \\
.2 \\
.1\end{array}$ & $\begin{array}{r}\mathbf{1 , 9 7 0} \\
\mathbf{3 3 7} \\
\mathbf{5 2 0} \\
\mathbf{2 6 0} \\
\mathbf{2 8 7} \\
\mathbf{4 6 3} \\
\mathbf{5 0 6} \\
\mathbf{5 9 2} \\
\mathbf{7 0 5} \\
\mathbf{7 5 0}\end{array}$ & $\begin{array}{l}86 \\
18 \\
35 \\
31 \\
12 \\
14 \\
10 \\
29 \\
18 \\
16\end{array}$ & $\begin{array}{r}3,2 \\
8 \\
8 \\
4 \\
4 \\
7 \\
8 \\
9 \\
1,1 \\
1,2\end{array}$ & & $\begin{array}{l}8.4 \\
8.3 \\
8.2 \\
8.4 \\
9.0 \\
9.0 \\
9.0 \\
8.9 \\
8.7 \\
8.7\end{array}$ & $\begin{array}{r}45 \\
50 \\
30 \\
30 \\
10 \\
10 \\
10 \\
12 \\
5 \\
5\end{array}$ & \multirow{2}{*}{\multicolumn{3}{|c|}{$\begin{array}{l}\text { Water from 86-126-foot zone. } \\
\text { Water from 94-96-foot zone. } \\
\text { Water from 92-95-foot zone. } \\
\text { Water from 109-121-foot zone. } \\
\text { Water from 183-209-foot zone. } \\
\text { Water from 272-282-foot zone. } \\
\text { Water from 297-305-foot zone. } \\
\text { After pumping 72 hours. } \\
\text { After pumping 730 hours. } \\
\text { After pumping about 1,550 } \\
\text { hours. } \\
\text { After pumping about } 1,900 \\
\text { hours. }\end{array}$}} \\
\hline & 8-25-65 & .2 & .1 & 782 & 21 & 1,3 & & 8.6 & 10 & & & \\
\hline
\end{tabular}




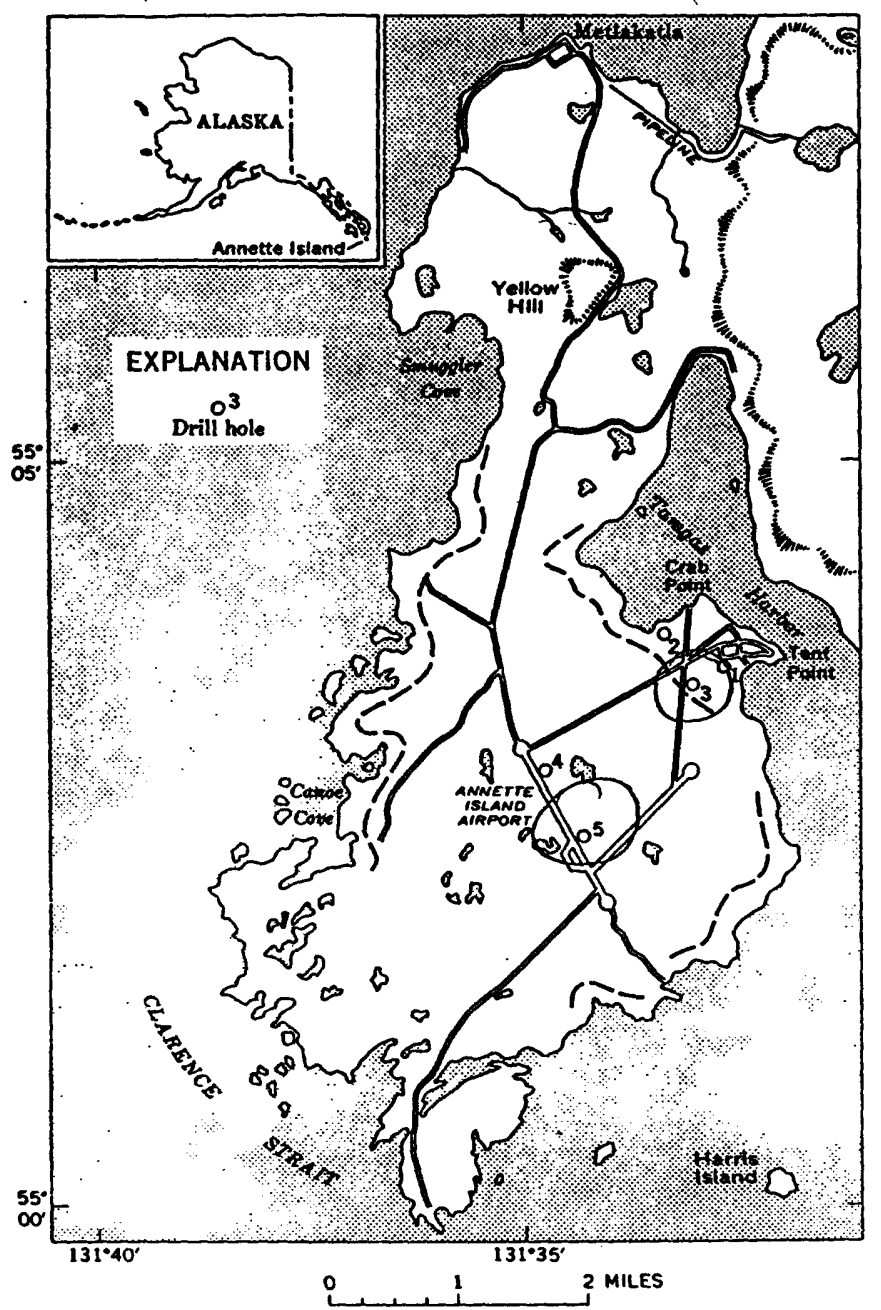

Figure 1.-Map of Metlakatla peninsula, Annette Island, Alaska, showing location of drill holes.

47-70 feet provided information on shallow subsurface joints. This core showed about 70 joints for an average of about three per foot. The width of these joints ranges from a hairline to about one-sixteenth inch, and many were partly or completely healed with quartz. Where the fractures were not fairly well healed, the core broke and the width of the fractures could not be determined. Because most of the fractures had been healed or were very narrow, the test hole did not yield a significant amount of water.

Highly fractured ultrabasic rocks south of Yellow Hill provide openings for seeps and small springs. Other small seeps issue from fractured rocks along the west side of the peninsula; these seeps undoubtedly go dry in the summer.

Rocks penetrated in the interval above $\mathbf{3 0 5}$ feet in the test well were nearly free of fractures, but zones of fractured rock were indicated below this depth by the difficulty experienced in maintaining a straight and round hole. Furthermore, the increase in well yield and reduction in drawdown described in the summary of test pumping suggest that the abundance of fractures increases with depth. The interval between 305 and 362 feet in the test well is interpreted as a fault rone because normally the number of fractures decreases with depth. Even though a fault zone may yield the major supply of ground water to the well, most recharge to the faults probably takes place through overlying jointed rock.

\section{Test drilling and pumping}

Results of test drilling and yield tests are summarized as follows:

Drill hole 1 reached a total depth of 295 feet and was abandoned because brackish water was obtained at that depth. A water-bearing zone, between 86 and 126 feet, was tested by pumping with air for 12 hours at a rate of one third gpm (gallon per minute).

Drill hole 2 reached a total depth of 113 feet. A waterbearing zone between 94 and 96 feet was tested by pumping with air at a rate of one-half $\mathrm{gpm}$ that increased to $1 \mathrm{gpm}$ after 30 hours.

Drill hole 3 reached a total depth of 215 feet. A waterbearing zone between 92 and 95 feet was pumped with air at a rate of two-thirds gpm for 4 hours but did not increase in yield.

Drill hole 4 reached a depth of 104 feet, but no water was obtained.

Drill hole 5 was drilled using a core drill to a depth of 305 feet. The hole was then redrilled for a test well to a depth of 362 feet using a 6 -inch churn drill. The results of testing the various water-bearing zones in this well are summarized below.

\section{Depth (feet)}

\section{Summary of testing}

$70-90 \ldots$. . Pumped with air $1 / 2 \mathrm{gpm}$ for 8 hours. Cemented in after pumping.

109-121 ... . Pumped with air $2 / 3$ gpm for 8 hours. Cemented in after

183-209 .... Pumped with air $2 / 3 \mathrm{gpm}$ for 8 hours. Cemented in after pumping.

272-282 .... Pumped with air 12/3 gpm for 8 hours. Cemented in

297-305 .... Pumped with air $8 \mathrm{gpm}$ for 24 hours.

$305-313 \ldots$. . Pumped with air $12 \% \mathrm{gpm}$ for 16 hours with 130 feet drawdown. Static level 10 feet.

313-320 ..... Pumped 16 hours at $30 \mathrm{gpm}$ with 94 feet of drawdown. Static level 13 feet.

321-326 .... Pumped 72 hours at $37 \mathrm{gpm}$ with drawdown of 80 feet. Static level 23 feet.

332-336 . . . . Pumped 23 hours at $37 \mathrm{gpm}$ with drawdown of $67 \mathrm{feet}$. Static level 23 feet.

Fresh ground water beneath Annette Island is in contact with sea water. Excessive lowering of the water table in a pumping well may cause salt water to enter and contaminate the aquifer. To forestall such a possibility, drawdown in the well must be carefully controlled.

To estimate the amount of drawdown after pumping the production well for an extended period of time and to estimate the long-term yield, a 12-hour recovery test was run. Analysis of the test data indicates that impermeable boundaries are present in the vicinity of the well and that the initial 


\title{
RECONNAISSANCE OF GROUND-WATER SUPPLIES FROM BEDROCK IN THE METLAKATLA PENINSULA, ANNETTE ISLAND, ALASKA
}

\author{
By MELVIN V. MARCHER, Oklahoma City, Okla.
}

Work done in cooperation with the Federal Aviation Administration

\begin{abstract}
Bedrock in the westem part of Annette Island, herein referred to as the Metlakatla peninsula, consists of igneous and metamorphic rocks that yield water only from fractures. $A$ test well. 362 feet deep, obtained water between 305 and 362 feet. Initial production of the well was $100 \mathrm{gpm}$ (gallons per minute), but results from a 12-hour recovery test auggested that this rate probably could not be maintained because of hydrologic boundaries. When the well was pumped continuously at a rate of $35 \mathrm{gpm}$ for more than 3 months, the water level declined 125 feet at an average rate of 0.6 foot per day to about 115 feet below sea level. Chemical analyses show that ground water is a sodium bicarbonate type. During pumping of the test well, the chloride content of the water increased from 75 to $222 \mathrm{mg} /$ (milligrams per liter) indicating that salt water was entering the aquifer.
\end{abstract}

Although annual precipitation in southeastern Alaska is as much as 269 inches, the igneous and metamorphic rocks underlying most of the region generally yield only small amounts of water. This report describes the results of a project to develop ground-water supplies from bedrock on Annette Island. Some of the conclusions derived from the project are applicable to other areas because the climate, topography, and geology of the island are typical of much of southeastern Alaska.

As a major part of the project, five small-diameter holes were drilled to determine the subsurface distribution of fracture zones and, where possible, to test the water-yielding capabilities of each zone. Drill hole 5 had the greatest potential as a source of water and, therefore, was redrilled as a test well. Each water-bearing zone in this well was tested for yield, a water sample collected for chemical analysis, and, upon completion of drilling, a 12-hour recovery test was made.

Interbedded gravel, sand, silt, and clay interpreted as raised beach deposits, which may be potential sources of ground water, were studied in some detail and are described more fully in a companion paper (Marcher, 1971) (p. D202-D205, this chapter).

\section{GENERAL SETTING}

Annette Island is in extreme southeastern Alaska (fig. 1). The western part of the island, an area of about 20 square miles herein referred to as the Metlakatla peninsula, is mostly a swampy, heavily vegetated lowland generally less than 200 feet above sea level.

Annette Island lies in the Wrangell-Revillagigedo belt of metamorphic rocks (Buddington and Chapin, 1929, p. 181-183). Mapping by Berg (1969) shows that bedrock in the Metlakatla peninsula is chiefly schist, gneiss, and hornfels. These rocks are locally mixed and in part gradational with, foliated granitic rocks, which, in turn, grade into foliated quartz diorite and diorite. An area of about 1.5 square miles in the vicinity of Yellow Hill is underlain by dunite and pyroxenite. Sedimentary rocks include muck, glacial till, and raised beach deposits.

\section{GROUND WATER IN BEDROCK}

\section{Bedrock fractures}

The number, spacing, attitude, size, and interconnection of fractures such as joints and faults control the occurrence, storage, and movement of ground water in bedrock in the Metlakatla peninsula. Observations, mainly along the beach, showed a wide variety in the degree and type of jointing. For example, in some areas three sets of uniform, well-developed joints in coarse-grained dioritic rocks intersect to produce sharply defined trihedral blocks. Elsewhere, similar rocks are rather thoroughly fractured but the fractures do not follow any discernible pattern. Measurements showed that the major sets of joints strike between $\mathrm{N} .15^{\circ} \mathrm{E}$. and $\mathrm{N} .15^{\circ} \mathrm{W}$. Other sets strike N. $25^{\circ}-35^{\circ}$ E. and N. $55^{\circ}-65^{\circ}$ W. Of 63 measurements of joint dips, about 47 percent dip at angles greater than $80^{\circ}$, and nearly 95 percent dip at angles greater than $45^{\circ}$.

A 23-foot drill core taken from drill hole 4 from a depth of 


\section{APPENDIX 6}

Data for Annette Island, Alaska 


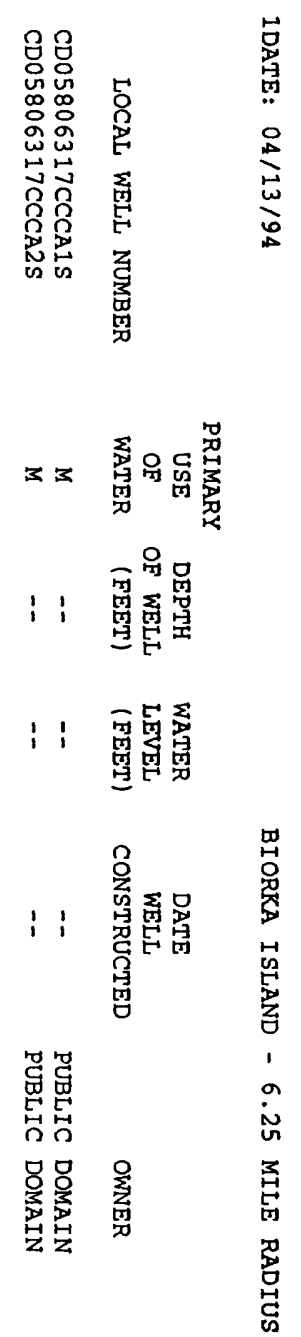

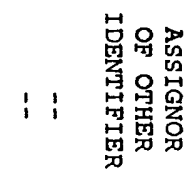

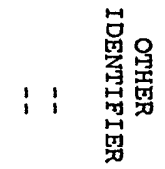

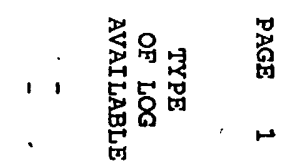




\section{APPENDIX 5}

Data for Biorka Island, Alaska 
WATER-QUALITY DATA, WATER YEAR OCTOBER 1967 TO SEPTEMBER 1968

\begin{tabular}{|c|c|c|c|c|c|c|c|c|c|c|c|}
\hline DATE & $\begin{array}{c}\text { CARBON } \\
\text { DIOXIDE } \\
\text { DIS- } \\
\text { SOLVED } \\
\text { (MG/L } \\
\text { AS CO2) } \\
(00405)\end{array}$ & $\begin{array}{l}\text { ALKA- } \\
\text { LINITY } \\
\text { WAT WH } \\
\text { TOT FET } \\
\text { FIELD } \\
\text { XG/L AS } \\
\text { CACO3 } \\
(00410)\end{array}$ & $\begin{array}{c}\text { BICAR- } \\
\text { BONATE } \\
\text { WATER } \\
\text { WH FET } \\
\text { FIELD } \\
\text { KG/L AS } \\
\text { HCO3 } \\
(00440)\end{array}$ & $\begin{array}{c}\text { CAR- } \\
\text { BONATE } \\
\text { WATER } \\
\text { WH FET } \\
\text { FIELD } \\
\text { MG/L AS } \\
\text { CO3 } \\
(00445)\end{array}$ & $\begin{array}{c}\text { NITRO- } \\
\text { GEN, } \\
\text { NITRATE } \\
\text { DIS- } \\
\text { SOLVED } \\
\text { (MG/L } \\
\text { AS N) } \\
(00618)\end{array}$ & $\begin{array}{l}\text { HARD- } \\
\text { NESS } \\
\text { TOTAL } \\
\text { (MG/L } \\
\text { AS } \\
\text { CACO3) } \\
(00900)\end{array}$ & $\begin{array}{l}\text { HARD- } \\
\text { NESS } \\
\text { NONCARB } \\
\text { WH WAT } \\
\text { TOT FLD } \\
\text { MG/L AS } \\
\text { CACO3 } \\
(00902)\end{array}$ & $\begin{array}{l}\text { CALCIUM } \\
\text { DIS- } \\
\text { SOLVED } \\
\text { (MG/L } \\
\text { AS CA) } \\
(00915)\end{array}$ & $\begin{array}{c}\text { MAGNE- } \\
\text { SIUM, } \\
\text { DIS- } \\
\text { SOLVED } \\
\text { (MG/L } \\
\text { AS MG) } \\
\text { (00925) }\end{array}$ & $\begin{array}{l}\text { SODIUM, } \\
\text { DIS- } \\
\text { SOLVED } \\
\text { (MG/L } \\
\text { AS NA) } \\
(00930)\end{array}$ & $\begin{array}{c}\text { SODIUM } \\
\text { AD- } \\
\text { SORP- } \\
\text { TION } \\
\text { RATIO } \\
(00931)\end{array}$ \\
\hline
\end{tabular}

JUN

$\begin{array}{llllllllllll}14 \ldots & 25 & 63 & 77 & 0 & 0.140 & 91 & 28 & 30 & 4.0 & 7.0 & 0.3\end{array}$

\begin{tabular}{|c|c|c|c|c|c|c|c|c|c|c|c|}
\hline & & & & & & & & $\begin{array}{l}\text { DIS- } \\
\text { CHARGE. }\end{array}$ & & & $\begin{array}{c}\text { PH } \\
\text { WATER }\end{array}$ \\
\hline DATE & TIME & $\begin{array}{c}\text { LAT- } \\
\text { I- } \\
\text { TUDE }\end{array}$ & $\begin{array}{l}\text { LONG- } \\
\text { I- } \\
\text { TUDE }\end{array}$ & $\begin{array}{l}\text { MEDIUM } \\
\text { CODE }\end{array}$ & $\begin{array}{c}\text { SAMPLE } \\
\text { TYPE }\end{array}$ & $\begin{array}{l}\text { RECORD } \\
\text { NUMBER }\end{array}$ & $\begin{array}{c}\text { TEMPER- } \\
\text { ATURE } \\
\text { WATER } \\
\text { (DEG C) } \\
(00010)\end{array}$ & $\begin{array}{c}\text { CUBIC } \\
\text { FEET } \\
\text { PER } \\
\text { SECOND } \\
(00061)\end{array}$ & $\begin{array}{l}\text { (PLAT- } \\
\text { INUM- } \\
\text { COBALT } \\
\text { UNITS) } \\
(00080)\end{array}$ & $\begin{array}{l}\text { CON- } \\
\text { DUCT- } \\
\text { ANCE } \\
\text { (US/CM) } \\
(00095)\end{array}$ & $\begin{array}{c}\text { FIELD } \\
\text { (STAND- } \\
\text { ARD } \\
\text { UNITS) } \\
(00400)\end{array}$ \\
\hline
\end{tabular}

JUN

$\begin{array}{llllllllllllll}14 \ldots & 1740 & 591409 \mathrm{~N} & 1352813 \mathrm{~W} & 9 & 9 & 96800099 & 11.0 & 3.0 & 15 & 218 & 6.7\end{array}$

\begin{tabular}{|c|c|c|c|c|c|c|c|c|c|c|c|}
\hline DATE & $\begin{array}{l}\text { SODIUM } \\
\text { PERCENT } \\
\text { (00932) }\end{array}$ & $\begin{array}{c}\text { POTAS- } \\
\text { SIUM, } \\
\text { DIS- } \\
\text { SOLVED } \\
\text { (MG/L } \\
\text { AS K) } \\
(00935)\end{array}$ & $\begin{array}{l}\text { CHLO- } \\
\text { RIDE, } \\
\text { DIS- } \\
\text { SOLVED } \\
\text { (MG/L } \\
\text { AS CL) } \\
(00940)\end{array}$ & $\begin{array}{l}\text { SULFATE } \\
\text { DIS- } \\
\text { SOLVED } \\
\text { (MG/L } \\
\text { AS SO4) } \\
(00945)\end{array}$ & $\begin{array}{l}\text { FLUO- } \\
\text { RIDE, } \\
\text { DIS- } \\
\text { SOLVED } \\
\text { (MG/L } \\
\text { AS F) } \\
(00950)\end{array}$ & $\begin{array}{l}\text { SILICA, } \\
\text { DIS- } \\
\text { SOLVED } \\
\text { (MG/L } \\
\text { AS } \\
\text { SIO2) } \\
(00955)\end{array}$ & $\begin{array}{l}\text { SOLIDS, } \\
\text { SUM OF } \\
\text { CONSTI- } \\
\text { TUENTS, } \\
\text { DIS- } \\
\text { SOLVED } \\
\text { (MG/L) } \\
(70301)\end{array}$ & $\begin{array}{l}\text { SOLIDS, } \\
\text { DIS- } \\
\text { SOLVED } \\
\text { (TONS } \\
\text { PER } \\
\text { DAY) } \\
(70302 \text { ) }\end{array}$ & $\begin{array}{c}\text { SOLIDS, } \\
\text { DIS- } \\
\text { SOLVED } \\
\text { (TONS } \\
\text { PER } \\
\text { AC-FT) } \\
\text { (70303) }\end{array}$ & $\begin{array}{l}\text { NITRO- } \\
\text { GEN, } \\
\text { NITRATE } \\
\text { DIS- } \\
\text { SOLVED } \\
\text { (MG/L } \\
\text { AS NO3) } \\
\text { (71851) }\end{array}$ & $\begin{array}{l}\text { IRON } \\
\text { (UG/L } \\
\text { AS FE) } \\
(71885)\end{array}$ \\
\hline
\end{tabular}
JUN

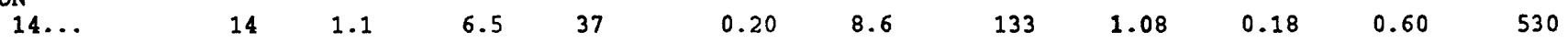


WATER-QUALITY DATA, WATER YEAR OCTOBER 1966 TO SEPTEMBER 1967

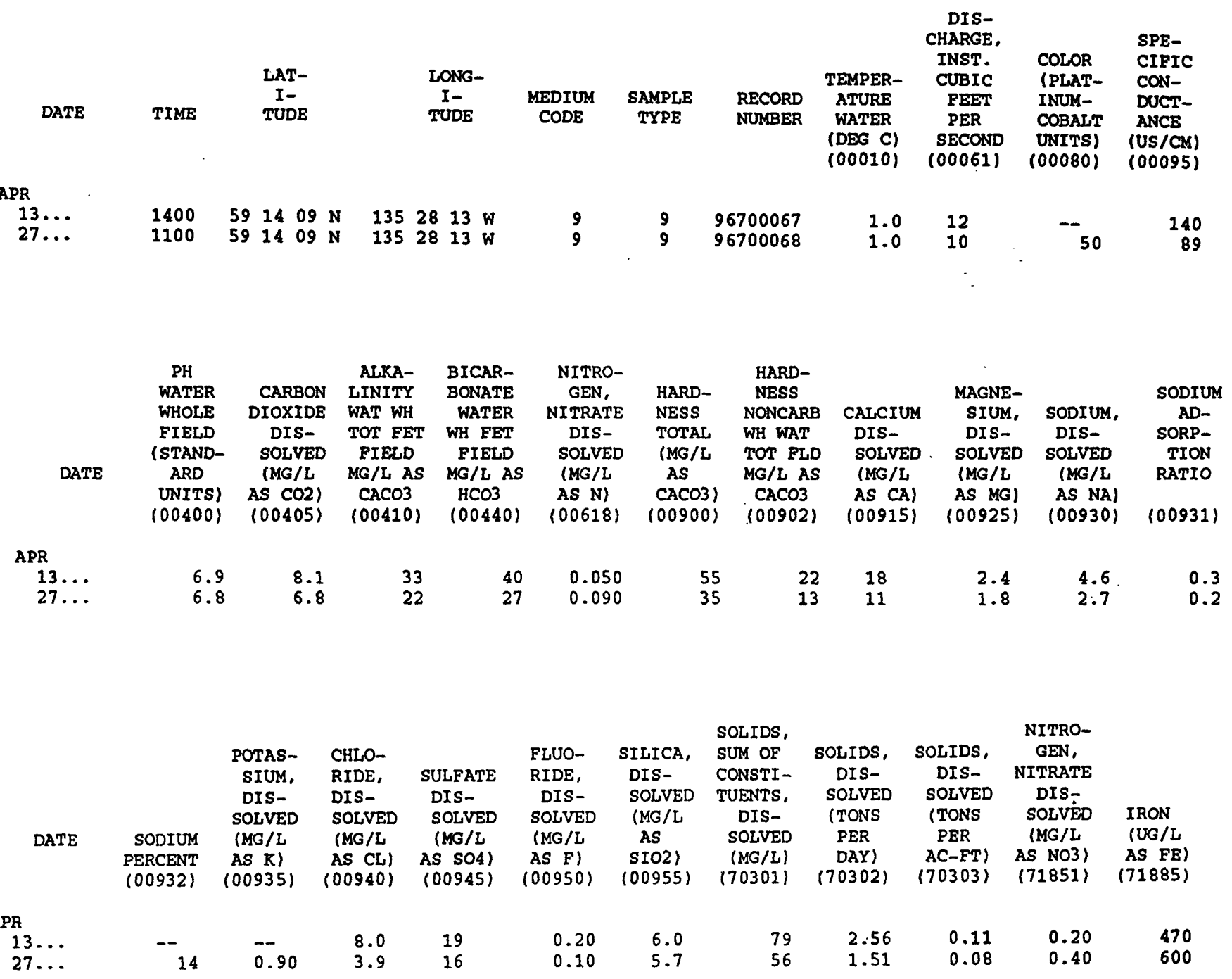


near Haines, Alaska - Continued

\begin{tabular}{|c|c|c|c|c|c|}
\hline $\begin{array}{c}\text { Diameter } \\
\text { of } \\
\text { casing } \\
\text { (inches) }\end{array}$ & $\begin{array}{c}\text { Use } \\
\text { of } \\
\text { water }\end{array}$ & $\begin{array}{c}\text { Depth } \\
\text { to } \\
\text { water }\end{array}$ & $\begin{array}{c}\text { Altitude } \\
\text { of land } \\
\text { surface }\end{array}$ & $\begin{array}{c}\text { Date of } \\
\text { measurement }\end{array}$ & Remarks \\
\hline N & TW & 183.0 & GS, L, D & \\
N & TW & 127.0 & GS, L, D \\
\hline
\end{tabular}

wells and streams near Haines, Alaska

\begin{tabular}{|c|c|c|c|c|c|c|c|c|}
\hline \multirow{2}{*}{$\begin{array}{l}\text { Chloride } \\
(\mathrm{CD})^{2}\end{array}$} & \multirow{2}{*}{$\begin{array}{c}\text { Fluoride } \\
(\mathrm{F})^{2}\end{array}$} & \multirow{2}{*}{$\begin{array}{l}\text { Nitrate } \\
\left(\mathrm{NO}_{3}\right)^{2}\end{array}$} & \multicolumn{2}{|c|}{$\begin{array}{l}\text { Hardness } \\
\text { as } \mathrm{CaCO}_{3}\end{array}$} & \multirow{2}{*}{$\begin{array}{c}\text { Specific } \\
\text { conductance } \\
\text { (micromhos } \\
\text { at } 25^{\circ} \mathrm{C} \text { ) }\end{array}$} & \multirow{2}{*}{$\begin{array}{c}\text { Total } \\
\text { dissolved } \\
\text { solids }^{2}\end{array}$} & \multirow{2}{*}{$\mathrm{pH}$} & \multirow[b]{2}{*}{ Remarks $^{3}$} \\
\hline & & & $\begin{array}{l}\text { Calcium } \\
\text { magne- } \\
\text { sium }\end{array}$ & $\begin{array}{c}\text { Non- } \\
\text { carbonate }\end{array}$ & & & & \\
\hline 6.0 & 0.2 & 0.1 & 100 & 16 & 300 & 140 & 7.9 & \\
\hline 5.0 & .1 & .2 & 112 & 28 & 255 & 145 & 7.9 & ADF (8837). \\
\hline 7.0 & .1 & .1 & 125 & 92 & 275 & 179 & 6.8 & \\
\hline 9.0 & .4 & .2 & 407 & 349 & 950 & 524 & 7.1 & . \\
\hline 5.0 & .2 & .1 & 164 & 19 & 350 & 170 & 7.6 & \\
\hline 14 & .2 & 2.1 & 105 & .0 & 450 & 251 & 7.2 & \\
\hline 6.0 & .0 & .0 & 165 & 74 & 383 & 253 & 7.9 & ADF (6359). \\
\hline 3.9 & .1 & .1 & 313 & 237 & 600 & 421 & 7.7 & ADF (8838). \\
\hline 4.0 & .1 & .0 & 235 & 160 & 600 & 340 & 7.9 & \\
\hline 198 & .5 & .1 & 179 & 40 & 1,020 & 543 & 7.3 & \\
\hline 6.7 & .0 & .6 & 62 & 5 & 138 & 82 & 7.0 & ADF (10I30); aresnic 0.00 \\
\hline 1,050 & .45 & .2 & 439 & 94 & 3,550 & 2,030 & 7.9 & After $1 \mathrm{hr}$., pump at $32 \mathrm{ft}$. \\
\hline 950 & .5 & .4 & 400 & 84 & 3,300 & 1,900 & 7.8 & After 2 hrs., pump at $32 \mathrm{ft}$. \\
\hline 10 & .2 & .2 & 60 & 2.0 & 160 & 80 & 7.3 & After $1 \mathrm{hr}$., pump at $22 \mathrm{ft}$. \\
\hline 3.0 & .2 & .2 & 684 & 607 & 1,200 & 877 & 7.6 & \\
\hline 60 & .1 & .1 & 107 & 12 & 442 & 246 & 7.7 & ADF (8836). \\
\hline 7.4 & .1 & .2 & 42 & 8 & 126 & 63 & 8.4 & ADF (8839). \\
\hline 2.0 & .1 & .1 & 20 & 2 & 50 & 27 & 6.0 & \\
\hline 1.0 & .1 & .1 & 25 & 4 & 57 & 35 & 7.0 & ADF (6731): $\sec 29 \mathrm{~T} 28 \mathrm{~S} \mathrm{R} 56 \mathrm{~F}$ \\
\hline 5.0 & .1 & 1.1 & 70 & 17 & 160 & 86 & 7.6 & ADr (O (J)); sec. $49,1.28$ S., R. 26 E. \\
\hline 5.0 & .2 & .2 & 165 & 83 & 300 & 157 & 7.4 & \\
\hline 3.9 & .1 & .4 & 35 & 13 & 89 & 56 & 6.8 & ADF (10129); arsenic 0.00 \\
\hline & & & & & & & & \\
\hline $\begin{array}{l}2.0 \\
6.0\end{array}$ & $\begin{array}{l}.1 \\
.0\end{array}$ & $\begin{array}{l}.2 \\
.0\end{array}$ & $\begin{array}{l}70 \\
48\end{array}$ & 19 & $\begin{array}{l}170 \\
113\end{array}$ & $\begin{array}{r}101 \\
72\end{array}$ & 7.3 & Sec. 6, T. 31 S., R. 59 E. \\
\hline & & & & 16 & 113 & 72 & 7.2 & ADF (6360) \\
\hline 2.8 & .5 & 1.2 & $7 I$ & 46 & 201 & 89 & 8.1 & ADF (8725); sec. 9, T. 30 S., R. 59 E. \\
\hline
\end{tabular}

${ }^{3} \mathrm{ADF}(\mathrm{)}=$ Additional data in files for laboratory analysis indicated.

${ }^{4}$ Sample locations that occur off map are not shown. 
Table 1.-Records of wells

\begin{tabular}{|c|c|c|c|c|c|}
\hline \multirow{2}{*}{ Well } & \multirow{2}{*}{.. File } & Map distance & \multirow{2}{*}{ Owner of user } & \multirow{2}{*}{$\begin{array}{c}\text { Year } \\
\text { com- } \\
\text { pleted }\end{array}$} & \multirow{2}{*}{$\begin{array}{c}\text { Depth of } \\
\text { well } \\
\text { (feet) }\end{array}$} \\
\hline & & $\begin{array}{l}\text { North } \quad \text { West } \\
\text { (feet) (feet) }\end{array}$ & & & \\
\hline 36 & 2bdd. & $2,750 \quad 3,000$ & Federal Aviation Agency & 1967 & 3 \\
\hline 37 & 2cad. & $1,950 \cdot 3,050$ & do do & 1967 & 58 \\
\hline
\end{tabular}

Table 2.-Quality-of-water analyses from

\begin{tabular}{|c|c|c|c|c|c|c|c|c|c|c|}
\hline $\begin{array}{c}\text { Sample } \\
\text { (well or } \\
\text { gaging site) }\end{array}$ & $\begin{array}{c}\text { Date } \\
\text { of } \\
\text { collection }\end{array}$ & Source & $\begin{array}{c}\text { Depth } \\
\text { of } \\
\text { well } \\
\text { (feet) }\end{array}$ & $\begin{array}{c}\text { Temp } \\
\text { ( } \mathrm{F})\end{array}$ & $\begin{array}{l}\text { rature } \\
\left.{ }^{\circ} \mathrm{C}\right)\end{array}$ & $\begin{array}{l}\text { Iron } \\
(\mathrm{Fe})^{2}\end{array}$ & $\begin{array}{l}\text { Calcium } \\
(\mathrm{Ca})^{2}\end{array}$ & $\begin{array}{c}\text { Magnesium } \\
(\mathrm{Mg})^{2}\end{array}$ & $\begin{array}{l}\text { Bicarbonate } \\
\left(\mathrm{HCO}_{3}\right)^{2}\end{array}$ & $\begin{array}{l}\text { Sulfate } \\
\left(\mathrm{SO}_{4}\right)^{2}\end{array}$ \\
\hline 4 & $4-10-67$ & Aluvium & 51 & 40 & 4.5 & 0.07 & 32 & 4.9 & 103 & 28 \\
\hline 6 & $3-12-66$ & _do do & 64 & - & - & .04 & 28 & 10 & 102 & 33 \\
\hline 7 & $4-30-67$ & do & 60 & 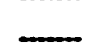 & $\ldots$ & .10 & 40 & 6.1 & 40 & 76 \\
\hline 8. & $4-10-67$ & _.do_ & 92 & 40 & 4.5 & .05 & 120 & 26 & 71 & 320 \\
\hline 9 & $4-6-67$ & do & 95 & 41 & 5.0 & .03 & 44 & 13 & 116 & 37 \\
\hline 10 & $4-6-67$ & do & 43 & $\ldots$ & سمس & .20 & 30 & 7.3 & 190 & 30 \\
\hline 11 & $12-5-60$ & _do_ & 60 & 42 & 5.5 & .18 & 51 & 9.3 & 111 & 98 \\
\hline 12 & $3-14-66$ & do_ & 64 & $\longrightarrow$ & - & .00 & 118 & 4.5 & 93 & 232 \\
\hline 13 & $5-2-67$ & - do & 284 & & $\ldots$ & .20 & 88 & 3.6 & 91 & 175 \\
\hline 21 & $4-14-67$ & do & 72 & 42 & 5.5 & .02 & 32 & 24 & 169 & 60 \\
\hline 22 & $4-27-67$ & _.do... & 22 & 40 & 4.5 & .00 & 20 & 2.9 & 70 & 5.0 \\
\hline 22 & $4-13-67$ & _.do_. & 32 & 40 & 4.5 & .05 & 44 & 80 & 421 & 36 \\
\hline 22 & $4-13-67$ & _do__ & 32 & 40 & 4.5 & .05 & 52 & 66 & 386 & 28 \\
\hline 22 & $4-13-67$ & _.do_ & 22 & 39 & 4.0 & .02 & 20 & 2.4 & 71 & 4.0 \\
\hline 23 & $7-25-67$ & _._. & 120 & $\ldots$ & - & .05 & 260 & 8.5 & 94 & 520 \\
\hline 26 & $3-\quad-67$ & ___do & 64 & $\ldots$ & $\ldots$ & .02 & 15 & 17 & 116 & 30 \\
\hline $32 \ldots$ & $3-14-67$ & ___do___ & 105 & - & $\ldots$ & .38 & 8.8 & 4.9 & 39 & 11 \\
\hline $35 \ldots$ & $4-22-67$ & do______ & 18 & 41 & 5.0 & .05 & 4.0 & 2.4 & 22 & 2.0 \\
\hline${ }^{4} 38$ & $7-5-61$ & Chilkat River & & - & - & .03 & 8.0 & 1.2 & 26 & 6.0 \\
\hline $40 \ldots$ & $4-21-67$ & Johnson Creek__ & 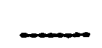 & 34.5 & 1.5 & .02 & 24 & 2.4 & 65 & 14 \\
\hline 41 & $4-15-67$ & $\begin{array}{l}\text { Haines Public } \\
\text { supply. }\end{array}$ & 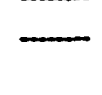 & - & - & .02 & 42 & 6.1 & 58 & 62 \\
\hline 42 & $4-27-67$ & Creek crossing & $\ldots$ & 34 & 1.5 & .60 & 11 & $1.8^{\circ}$ & 27 & 16 \\
\hline $443 \ldots$ & $4-21-67$ & $\begin{array}{l}\text { Sawmill Road. } \\
\text { Haska Creek }\end{array}$ & & 33.5 & 1.0 & .03 & 22 & 3.6 & 63 & 28 \\
\hline 44 & $12-6-60$ & $\begin{array}{l}\text { Port Chilkoot } \\
\text { public supply. }\end{array}$ & & - & - & .74 & 15 & 2.6 & 38 & 19 \\
\hline 45 & 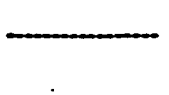 & $\begin{array}{l}\text { Tank Farm } \\
\text { supply. }\end{array}$ & - & - & - & 3.21 & 28 & .0 & 64 & 25 \\
\hline
\end{tabular}

${ }^{1}$ Sample numbers (4-35) are identical to well numbers on table 1 ; numbers $40-45$ refer to surface-water or publicsupply samples.

${ }^{2}$ Constituents given in milligrams per liter. 
Table 3. - Summary of ground-water availability in the Haines-Port Chilkoot area, Alaska

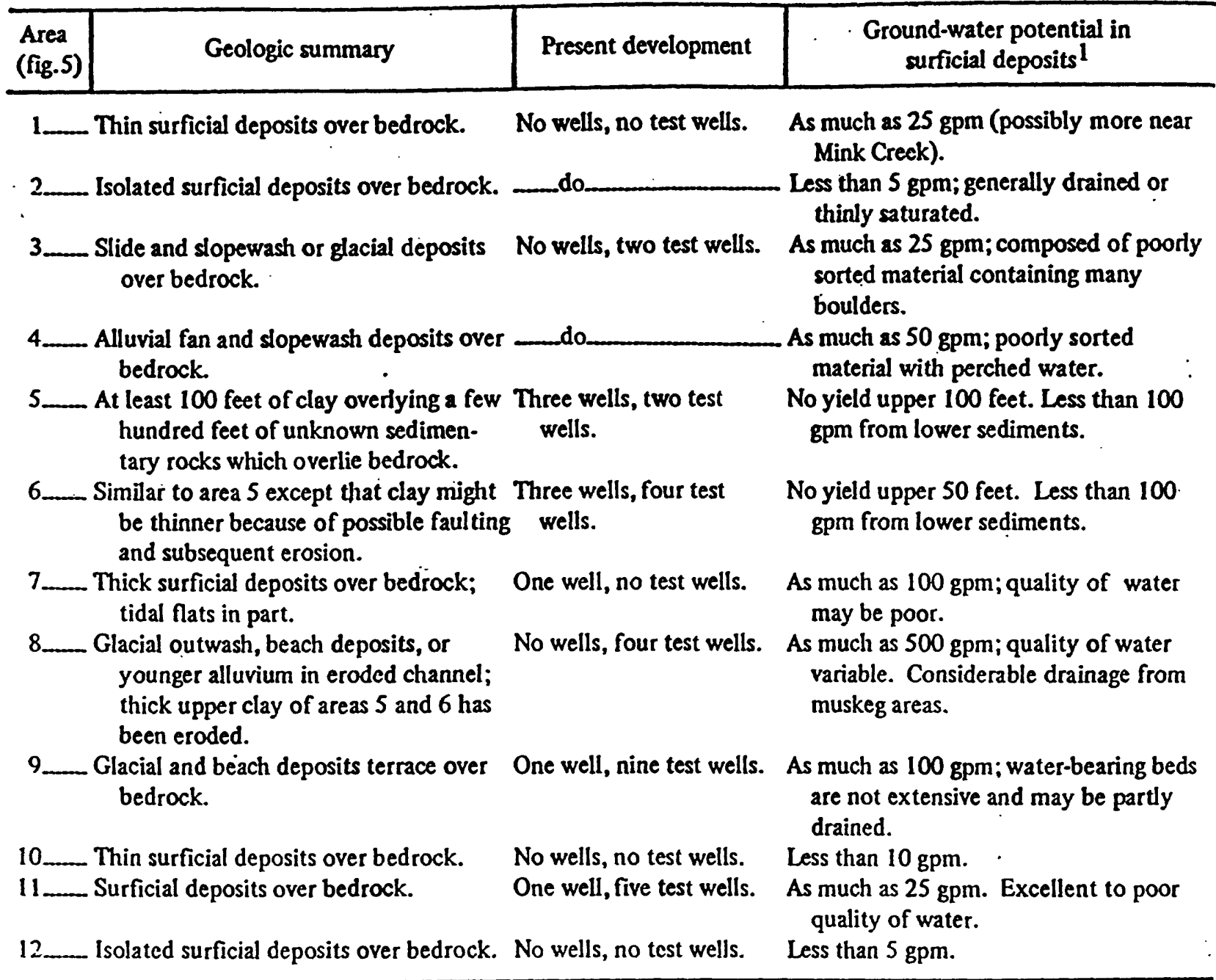

\footnotetext{
${ }^{1}$ Less than $5 \mathrm{gpm}$ from bedrock.
} 
Heines, Alaska

Material
Hole \# 1 at Highway Comm. Gurage March $4 ; 1966$

Fill of grown gravelly soil

0

4

Brown gravel with little silt, wet, very little

silt 10 to 13 feet mostly gravel, water 16 to $18^{\prime} \quad 4 \quad 18$

Clay, blue-gray soupy, mixed with gravel and sand $18 \quad 33$

Heavier clay mixed with gravel or sand, becoming

less dense at a depth of about 45 feet

$33 \quad 57$

Heavy clay mixed with fine gravel and sand, blue gray soupy

57

65

Fine sand and clay mixed, blue gray soupy

65

78

Sand or sand and clay mixedl soupy

78

87

About 35 feet of 2 inch casing with a 6 foot drive point put down the hole. 
Haines, Alaska

Hole 9

Material
March 8, 1966

Depth

Erom To

Sibil with small broken rock

0 .

2

Gravel and water, gravel fine to coarse with a brown silt matrix

2

Gravel with silt becoming more gray in color 5

Clay, very hard and dense, gray to blue-gray 10

Drills softer, possibly fine sand or silt, water 16

Harder drilling, clay sandy gray to blue gray with a band of gravel at about 24 fert

Drills like sand or soft clay, witb some fine gravel, more gravel at about $45 \mathrm{fcet}$ water (no return)

24

53

Gravel

53

55

Soft again, clay or sand mixed with gravel

55

67

Gravel and heavy clay, coarse gravel at about

71 feet to 75 feet and more sandy below

Clay and gravel interbedded

77

87

So much gravel caved into the hole upon removal of the auger that it was not possible to put more than 15 feet of pipe in the hole, pipe pulled and hole filled. 
Material

Fill, sandy, dry

Clay, grey - blue, damp, soft

Clay, with sandy and pebble zones, tillite?

Sandy clay mixed with pebbles and gravel up to 3 inches in diameter, gray to blue in color

Sand fine with interbedded clay and minor gravel (no return) drills easily

Hard clay and gravel mixed (no return)

Clay and gravel coarse up to 3 inches in diameter hard drilling (no return)

Hard gravel (?) (no return)

Gravel with hard cling, very hard drilling (no return)

Very hard drilling (clay?) no return

Hit boulder or bedrock at depth of 50 feet

$\begin{array}{rr}\text { From } & \text { Depth } \\ 0 & \text { To } \\ 8 & 8 \\ 15 & 15 \\ 23 & 23 \\ & 30\end{array}$

30

$35 \quad 42$

$42 \quad 46$

$46 \quad 48$

$48 \quad 49$

$49 \quad 50$ 
Material

From Depth To

Sizz and rock mostly amall gravel, brow - fill?

Silt with gravel slightly larger than pea gravel, water in brownish black matrix

Gravel and silt, gravel slightly coraser than above rater

Silt or clay, less gravel than abore, blue-gray in color

Heavier clay, soft, blue gray in color, some material with more sand, more gravel after 38 feet and possibly in pure sand at 40 feet, mixed with blue clay 26

Heavy clay (no return) hard drilling, easier drilling after 51 feet and gravel at about 52 feet

Sand, mixed with gravel (no return)
4

10 
Depth (feet)

Soft rock with some hard rock and seams of soft.

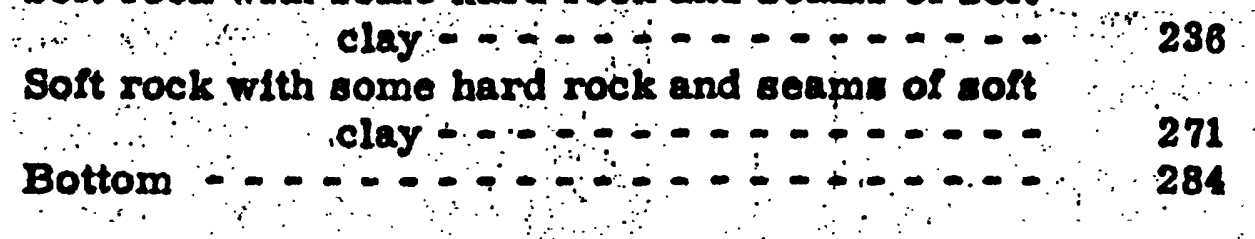

Results: Pumped well for 5 hourn. Maximum capacity with pump at 265-foot level was 15 G.P.M.: Sprung well with 3 shots of $21 \mathrm{lbs}$. dynamite each at approximately 210-foot, 240-foot, and 270-foot levels. Well was pumped constantly, but average yield was only 15 G. P. Mo, so the well was abandoned. 
Log of water well No, 2. Halnes, Alanka, drilled by Foley. Brothery, Inc, 3 Aguat-September, 1843. Collar at 02.8 ifto; elevation.

site presumably O I mi: $E$ of intersection Allan and Canstock $12 d$ Depth (feet)

Surface gravel $\ldots \ldots \ldots \ldots \ldots 0$ Blue grey clay _................... $1-80^{\prime}$

Gravel; ellght water content - ......... 80

Sand and gravel; well made a small amount of water 81

Sand and gravel _................. 85

Coarse gravel and fine sand -.........

Blue grey clay - . . . . . . . . . . . . . . 98

Coarse gravel; very little sand content - . . . - . . 88

Large gravel and boulders up to 6 " In slze; some

$$
\text { sand } \ldots \ldots \ldots 106
$$

Gravel with some line sand ........... 111

Fine to large gravel with some fine sand ..... 118

Stopped drilling at 122 feet.

Casing was perforated with 7 holes at 116 then casing was perforated to within 32 of the top with 180 perforations; cleaned out the well, and installed test pump. Test showed about 15 G. P. M. .

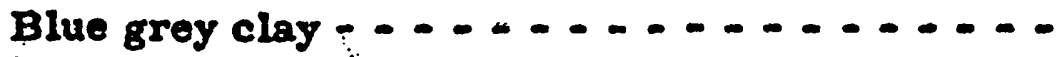

122

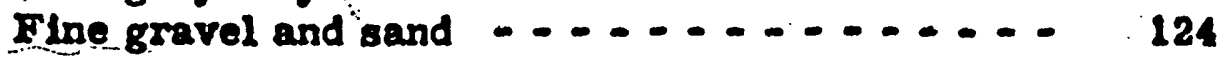

Hard rock .................. 130

Rock, sllghtly water bearing _.......... 137

Rock, slightly water bearing _........... 149

Rock, slightly water bearing .......... 169

Rock ........................ 175

Soft rock - . . . . . . . . . . . . . . . 182.

Solt porous rock _................ 187

Soft porous rock with seams of fine clay ..... 207.

Soft porous rock. Drilled to 296 feot and then

$\because$ pumped well for 4 hrs.: average yleld was 16 G. P. M. with drawdown to 166!..... 
Log of water well No, I, Halies, Alaska, drilled by Foley Brothers, Ince August, 1948 , Collar at 40.0 fto elevation. site presumably O O rile E of customs house Depth (feet)

Muskeg _........... 0

Fine gravel contalning surface water $\ldots \ldots \ldots$ Blue grey clay ... $\ldots \ldots \ldots . \ldots . \ldots 4^{\prime}$

Flne gravel contalning surface water. . . . . . 44

Fine gravel mixed with clay - . . $\ldots \ldots \ldots$

Coarse gravel, clay and bouldera _....... 50

Fine grey sand with some 1/2" to 1-1/2" gravel.

Sand is water soaked; well made a small amount of water. $\ldots \ldots \ldots \ldots \ldots$

Fine grey sand with small amount 1/2" to 1-1/2".

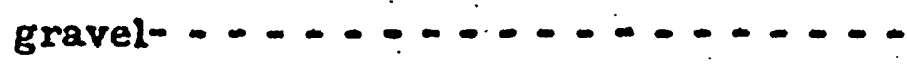

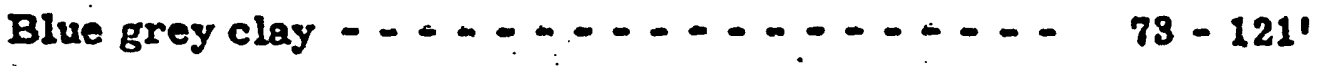

Fine water bearing band. Well made water at

approximately 35 G.P.M. Pressure forced

the water up 110 feot in well ....... 121 .

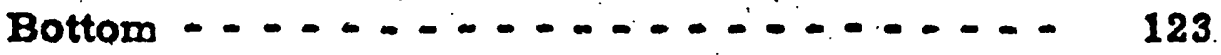

Results: Water found to be salty, and so the well was abandoned. 
Log of woll at rort ChIlkoot, Nlacky

\section{Iuterlal .. Thickness Dupth}

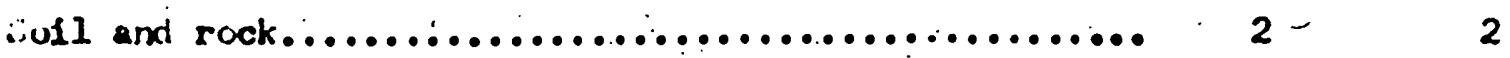

Brown oilty clay und rock..................... $17 \quad 19$

Luyered gravel ind electal clay................ 35 54

iouldors.................................. $2 . \ldots$

iravel..................................... 4.60

iimuliders, prevel uxd clay, wated................. 5 6s

iravel, corso to mediun..................... 7.72

(:lay, bluidh black............................ 3 75

Gravel, ar.a!., tadxed with clay, blue.............. .8. 83

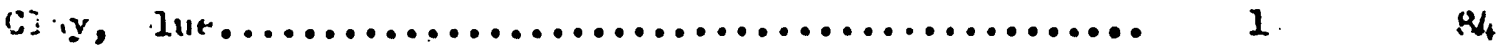

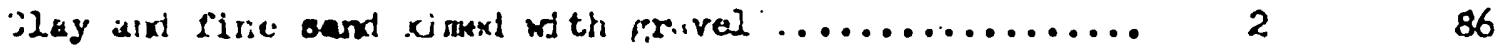

X.irivel, ci, sized (reportod)................. 14 105

jiny und i;ravel ntrod....................... 5 J10

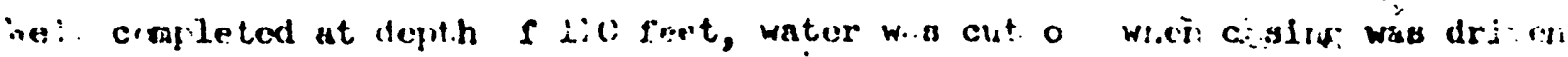

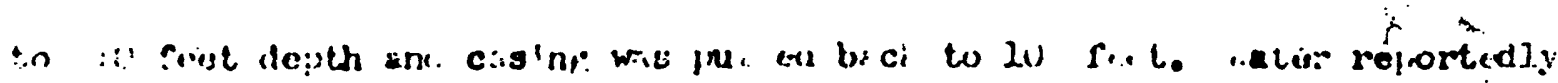

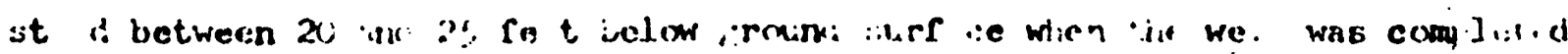

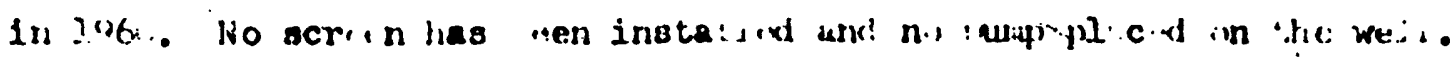

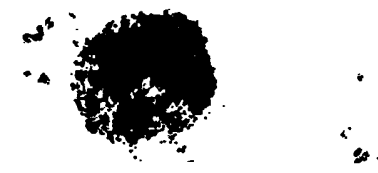




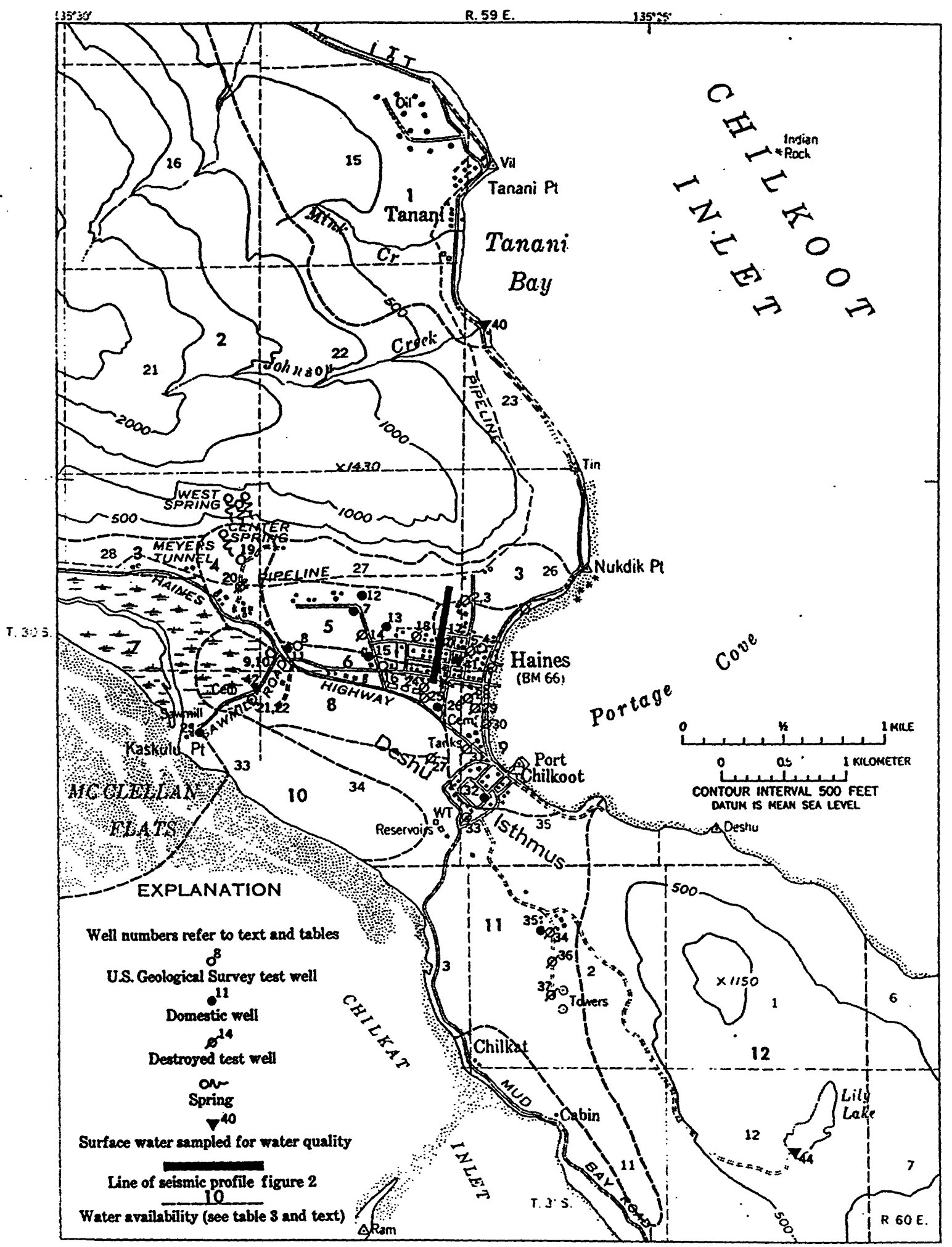

Base Irom U.S. Geological Survey

Figure 5.- Location of wells and sample sites and delineation of areas of ground water availability. 


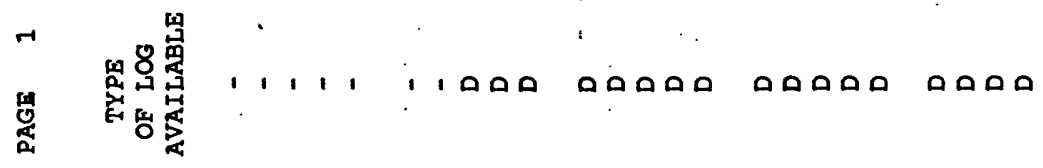

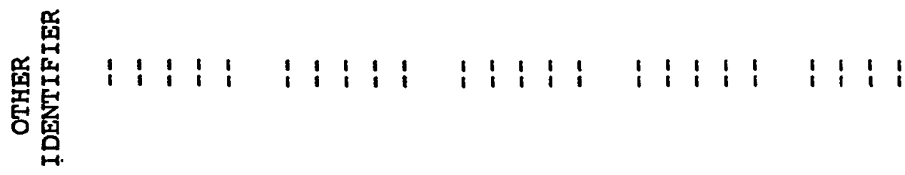

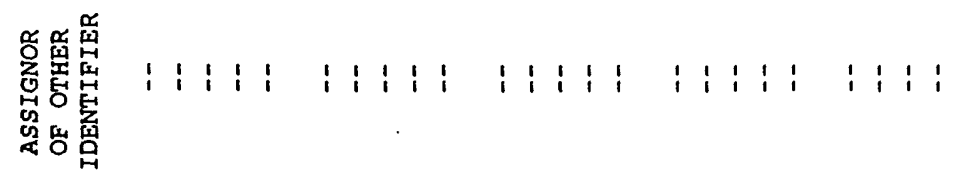

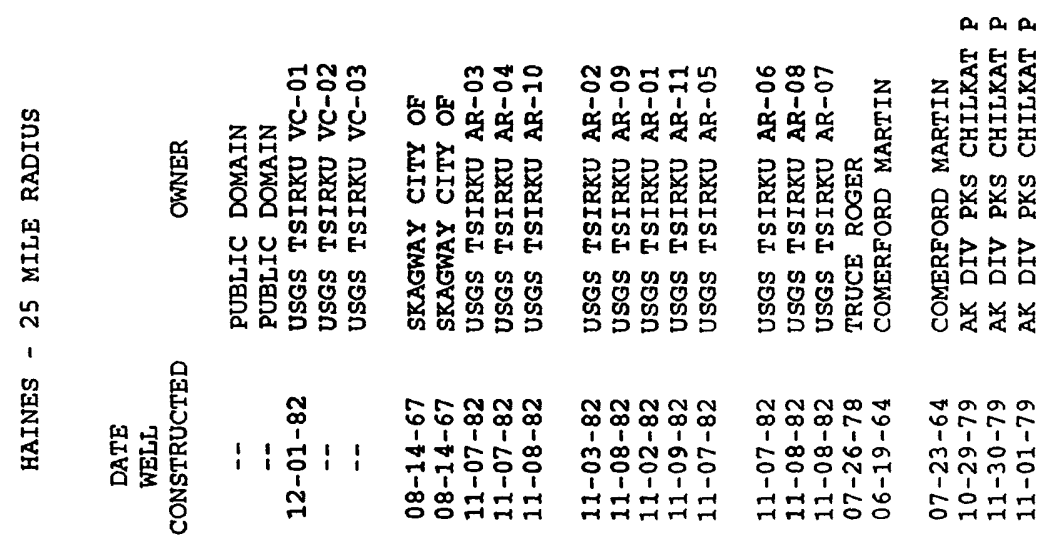

舀舅

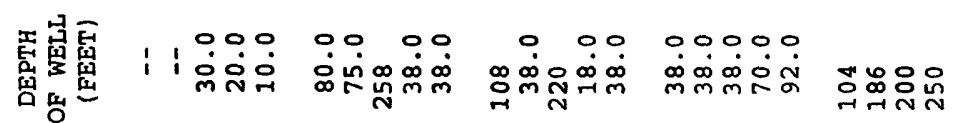

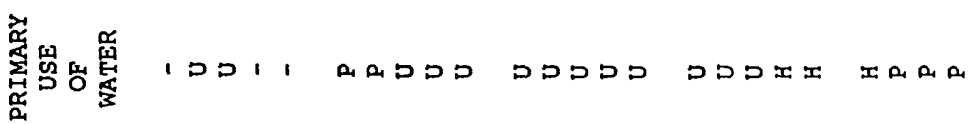

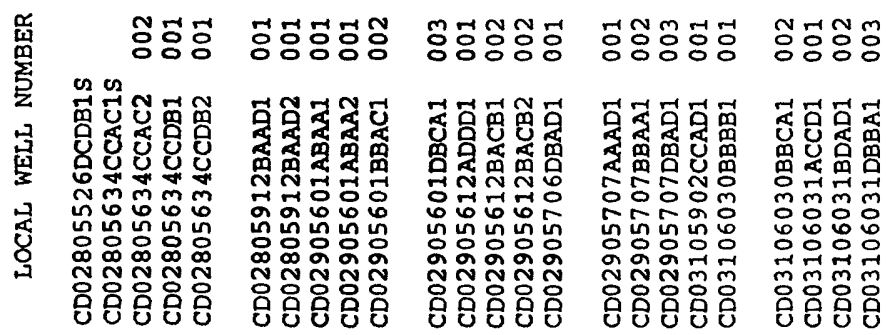


APPENDIX 4

Data for Haines, Alaska 


\section{WATER ANALYSIS}

Location

Source

Cased to (ft)

$-2+3$ Date drilled - Point of coll.

Cased to (ft)

Treatment

WBF

Temp ( ${ }^{\circ} \mathrm{F}$ )

Collected

Remarks

\section{Owner}

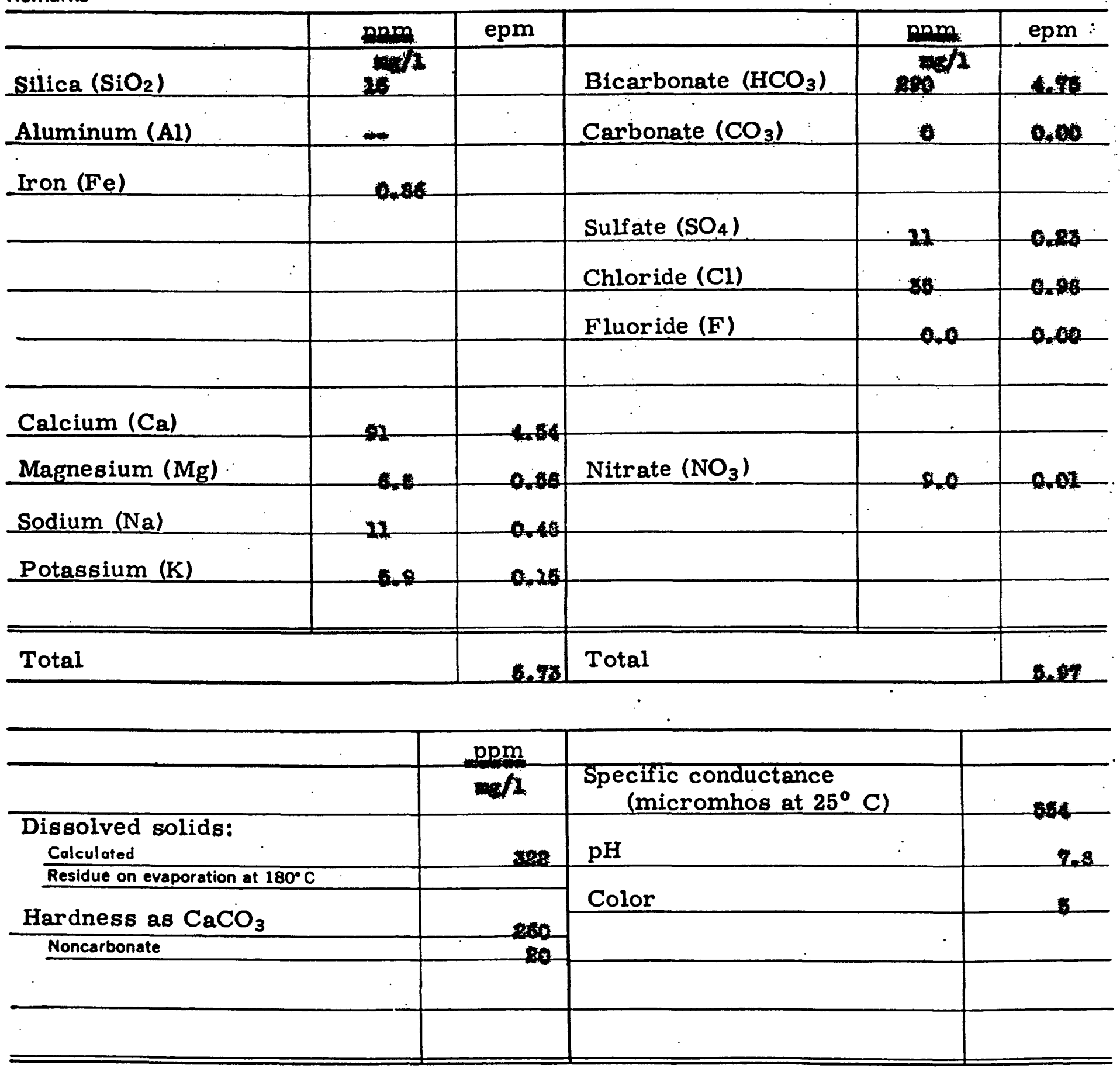

Lab. No. Cohrogat-de-247 Field No. 


\section{UNITED STATES DEPARTMENT OF THE INTERIOR GEOLOGIĆAL SURVEY}

WATER ANALYSIS

Location

Source

Cased to (ft)
FAA Stn, Gustavus, Alerska Shallow well, dug Date drilled

Owner

\section{Point of coll. Depth Well pimp}
County

Treatment

WBF

Temp ( $\left.{ }^{\circ} \mathrm{F}\right)$

Collected

Appear. when coll. 15:Apr. 19.59 Clear

WL Use

Remarks Return analysis toFAA, Box 440, Attn: ANT-675. BU, Anchorage, Alaska

\begin{tabular}{|c|c|c|c|c|c|}
\hline & $\mathrm{ppm}$ & epm & & $\mathrm{ppm}$ & epm \\
\hline Silica $\left(\mathrm{SiO}_{2}\right)$ & 12 & & Bicarbonate $\left(\mathrm{HCO}_{3}\right)$ & 244 & 4.00 \\
\hline Aluminum (Al) & & & Carbonate $\left(\mathrm{CO}_{3}\right)$ & & \\
\hline Iron (Fe) & 2.0 & & & & \\
\hline \multirow[t]{3}{*}{ Mn } & 0.39 & 0.01 & Sulfate $\left(\mathrm{SO}_{4}\right)$ & 53 & 1.10 \\
\hline & & & Chloride (Cl) & 9.0 & 0.25 \\
\hline & & & Fluoride (F) & 0.0 & 0.00 \\
\hline Calcium (Ca) & 75 & 3.74 & & . & \\
\hline Magnesium (Mg) & 15 & 1.23 & Nitrate $\left(\mathrm{NO}_{3}\right)$ & 0.0 & 0.00 \\
\hline Sodium (Na) & 6.5 & 0.28 & $\mathrm{PO}_{4}$ & 0.0 & 0.00 \\
\hline Potassium (K) & 3.9 & 0.10 & & & \\
\hline \multicolumn{2}{|l|}{ Total } & 5.36 & \multicolumn{2}{|l|}{ Total } & 5.35 \\
\hline
\end{tabular}

\begin{tabular}{|c|c|c|c|}
\hline & $\mathrm{ppm}$ & & \\
\hline & & $\begin{array}{l}\text { Specific conductance } \\
\left(\text { micromhos at } 25^{\circ} \mathrm{C}\right)\end{array}$ & 492 \\
\hline $\begin{array}{l}\text { Dissolved solids: } \\
\text { Colculated }\end{array}$ & 295 & ( & 6.7 \\
\hline Residue on evaporation at $180^{\circ} \mathrm{C}$ & & & \multirow{3}{*}{0} \\
\hline Hardness as $\mathrm{CaCO}_{3}$ & 248 & & \\
\hline Noncarbonate & 48 & & \\
\hline & & & \\
\hline & & & \\
\hline
\end{tabular}




\section{WATER ANALYSIS}

Location IAA Station Gustavis, Alaska Source Fell 22001 from housing area Cased to (ft) Date drilled Owner

Treatment

WBF

Temp ( $\left.{ }^{\circ} \mathrm{F}\right)$

Collected

Remarks Point of coll. Diam (in.) 3

\begin{tabular}{|c|c|c|c|c|c|}
\hline & $\mathrm{ppm}$ & epm & & $\mathrm{ppm}$ & epm \\
\hline Silice $\left(\mathrm{SiO}_{2}\right)$ & $3 / 4$ & & Bicarbonate $\left(\mathrm{HCO}_{3}\right)$ & 244 & 4.00 \\
\hline Aluminum (Al) & & & Carbonate $\left(\mathrm{CO}_{3}\right)$ & & \\
\hline Iron (Fe) In sol. & 0.02 & & & & \\
\hline Manganese (Un) Iitsol. & 0.03 & 0.00 & Sulfate $\left(\mathrm{SO}_{4}\right)$ & 40 & 0.83 \\
\hline & & & Chloride (Cl) & 4.0 & 0.21 \\
\hline & & & Fluoride (F) & 0.1 & 0.00 \\
\hline Calcium (Ca) & 6.4 & 0.32 & & . & \\
\hline Magnesium (Mg) & 1.9 & 0.16 & Nitrate $\left(\mathrm{NO}_{3}\right)$ & 0.1 & 0.00 \\
\hline Sodium $(\mathrm{Na})$ & 100 & 4.35 & & & \\
\hline Potassium (K) & 2.3 & 0.06 & & & \\
\hline Total & & 4.89 & Total & & 4094 \\
\hline
\end{tabular}

\begin{tabular}{|c|c|c|c|}
\hline & $\mathrm{ppm}$ & & \\
\hline & & $\begin{array}{l}\text { Specific conductance } \\
\left(\text { micromhos at } 25^{\circ} \mathrm{C}\right)\end{array}$ & 456 \\
\hline $\begin{array}{l}\text { Dissolved solids: } \\
\text { Colculated }\end{array}$ & 289 & 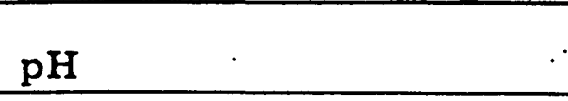 & 8.2 \\
\hline Residue on evaporation at $180^{\circ} \mathrm{C}$ & & Color & \\
\hline$\frac{\text { Hardness as } \mathrm{CaCO}_{3}}{\text { Noncarbonate }}$ & $\frac{24}{0}$ & Color & 0 \\
\hline $\begin{array}{r}\text { Alk as } \mathrm{CaOO}_{3} \\
\mathrm{CO}_{2} \\
\end{array}$ & $\begin{array}{r}2 \\
200^{2} \\
\end{array}$ & & \\
\hline
\end{tabular}

